\title{
46. THE QUATERNARY RECORD IN THE TYRRHENIAN AND IONIAN BASINS OF THE MEDITERRANEAN SEA
}

\author{
M. B. Cita, Institute of Paleontology, University of Milano, Milan, Italy \\ M. A. Chierici, AGIP Mineraria, San Donato Milanese, Milan, Italy \\ G. Ciampo, Institute of Paleontology, University of Naples, Naples, Italy \\ M. Moncharmont Zei, Institute of Paleontology, University of Naples, Naples, Italy \\ S. d'Onofrio, Institute of Geology, University of Bologna, Bologna, Italy \\ W. B. F. Ryan, Lamont-Doherty Geological Observatory of Columbia University, Palisades, New York \\ and \\ R. Scorziello, Institute of Paleontology, University of Naples, Naples, Italy
}

\section{INTRODUCTION}

Two Quaternary sections of deep-sea sediments suitable for paleoecologically oriented investigations were recovered in the Mediterranean Sea during Leg 13 of the Deep Sea Drilling Project (August-October, 1970). Both were selected in order to obtain continuous stratigraphic records of open marine sedimentation - one for the Tyrrhenian Basin and one for the Ionian Basin.

\section{Site 132}

Site 132, in the Tyrrhenian Basin, was located near the crest of a smooth swell west of the central bathyal plain. This location provided the chance to sample a sequence of basically biogenic sediment. This site was purposely located near areas where type or reference sections of the late Pliocene and early, middle, and late Pleistocene marine stages have been established. Also included is the type locality for the Plio-Pleistocene boundary (Figure 1). Inasmuch as Site 132 was continuously cored to the Miocene, all of these time intervals could be delineated in the sedimentary and fossil records. No stratigraphic gaps were found.

The Quaternary lithologic succession at Site 132 is rather uniform and consists of purely pelagic nannoforaminiferal oozes. Tephra layers are common, especially in the upper part of the section. The Quaternary section at Site 132 is about 70 meters thick and conformably overlies Upper Pliocene strata of similar lithology.

\section{Site $\mathbf{1 2 5}$}

Drilling was conducted well up on the gently arched Mediterranean Ridge at a location about midway between Africa and Europe. Because of this, it was possible to obtain a sedimentary sequence at Site 125 in a pelagic environment of the Ionian Basin that is not only free of turbidites, but which contains a complex record of stagnations, climatic fluctuations, and sediment dispersal. There was concern about finding an adequate site in the eastern Mediterranean when analysis of the more than 100 existing piston cores showed that although pelagic sediments occur along the crest of the Mediterranean Ridge, the unusually hummocky surface of the ridge is conducive to slumping and shortened sections. Consequently, Site 125 was targeted along a pre-survey seismic reflection profile (Figure 2) where the thickness of the acoustically transparent sediment above Horizon $\mathrm{M}$ is highly uniform, and where the mean relief of the crescent echo sequences is unusually low (less than 10 meters in amplitude). As it turned out, this location afforded an opportunity to penetrate a nearly complete sequence of Pleistocene to Lower Pliocene biogenic oozes before encountering a Messinian evaporite series at the M-Reflectors.

\section{Purpose}

The purpose of this preliminary report is to offer a briefing to interested personnel concerning aspects of the Quaternary record which probably would not have been touched upon in a routine core description. The objective is to emphasize the usefulness of sections at Sites 125 and 132 for future detailed geological investigations. The scope has been limited by time and design to the investigation of these sections in order to (a) discover whether a useful Mediterranean stratigraphic sequence has indeed been recovered; (b) see if this sequence can be correlated to Mediterranean land sections; (c) learn if it contains a reliable paleomagnetic chronology to which the various biostratigraphic levels and periods of volcanic activity can be referred; and (d) probably most important to us, to see if the planktonic fauna in the sediment records evidence of climatic fluctuations corresponding to the European Pleistocene glaciations.

An attempt will be made to show that although some of the recorded events at these two sites are possibly of local interest in terms of Mediterranean problems, others are of more general significance and deserve direct and rapid reporting; hence, this compilation. It appears that the most interesting phase of study on the Mediterranean cores is just beginning and it is hoped that our observations will be of use to the more detailed investigations that will follow.

\section{Incomplete Uppermost Quaternary Sections}

Unfortunately, the initial coring attempts at Sites 125 and 132 failed to recover the topmost part of the section.

The stratigraphic succession of the last 300 to 400 thousand years, which is recognizable in Lamont-Doherty Geological Observatory piston core RC9-185 (Ryan, in press), about $35 \mathrm{~km}$ southwest of Site 125 , and which is 


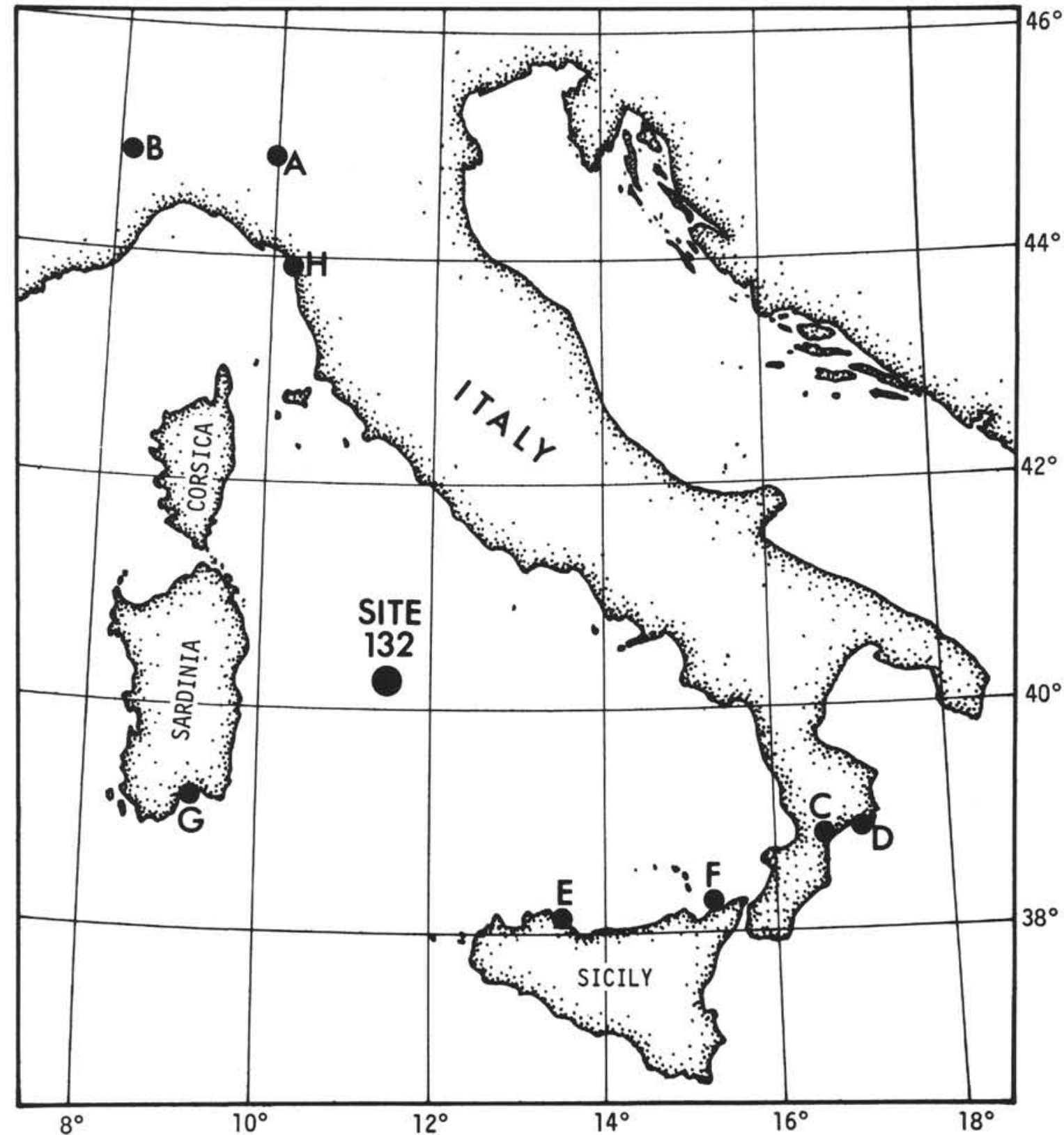

Figure 1. Geological setting of Site 132 in the Tyrrhenian Basin. The location on a small isolated swell above the level of the central abyssal plain is shown on a processed seismic profile of Finetti, Morelli, and Zarudzki (1970). The letters shown on the accompanying map indicate type localities of the Pliocene and Pleistocene marine stages and of the type locality for the Pliocene-Pleistocene boundary. A = Castellarquato near Pliacenza: (Emilia) type Piacenzian (middle-late Pliocene) $\mathrm{B}=$ Valle Andona near Asti: (Piedmont) type Astian (late Pliocene) C $=$ Santa Maria di Catanzaro (Calabria): type Calabrian (early Pleistocene) $\mathrm{D}=$ Le Castella near Crotone (Calabria): type locality for the Pliocene-Pleistocene boundary (INQUA Congress, 1965) E=Ficarazzi, near Palermo (Sicily): type Sicilian (lower Pleistocene) $\mathrm{F}=$ Milazzo (Sicily): type Milazzian (middle Pleistocene) G = Cala Mosca near Cagliari (Sardinia): type Tyrrhenian (late Pleistocene) $\mathrm{H}=$ Versilia (Tuscany): type Versilian (latest Pleistocene). No type sections or type localities have been designated for the Emilian Stage (middle-lower Pleistocene) as defined by Ruggieri and Selli (1950).

also found in other piston cores throughout the Ionian Basin (Parker, 1958; Olausson, 1961, 1965; GrazziniVergnaud and Herman-Rosenberg, 1969; Herman, 1971a, b; Pastouret, 1970; Hesse, et al., 1971) was not found in the first core cut beneath the sea floor at Site 125. In particular, a series of tephra layers interbedded in and between layers of black sapropel mud in piston core RC9-185 was not found at Site 125. It thus appears that possibly up to ten meters of the section at Site 125 were bypassed in the spudding-in process. 


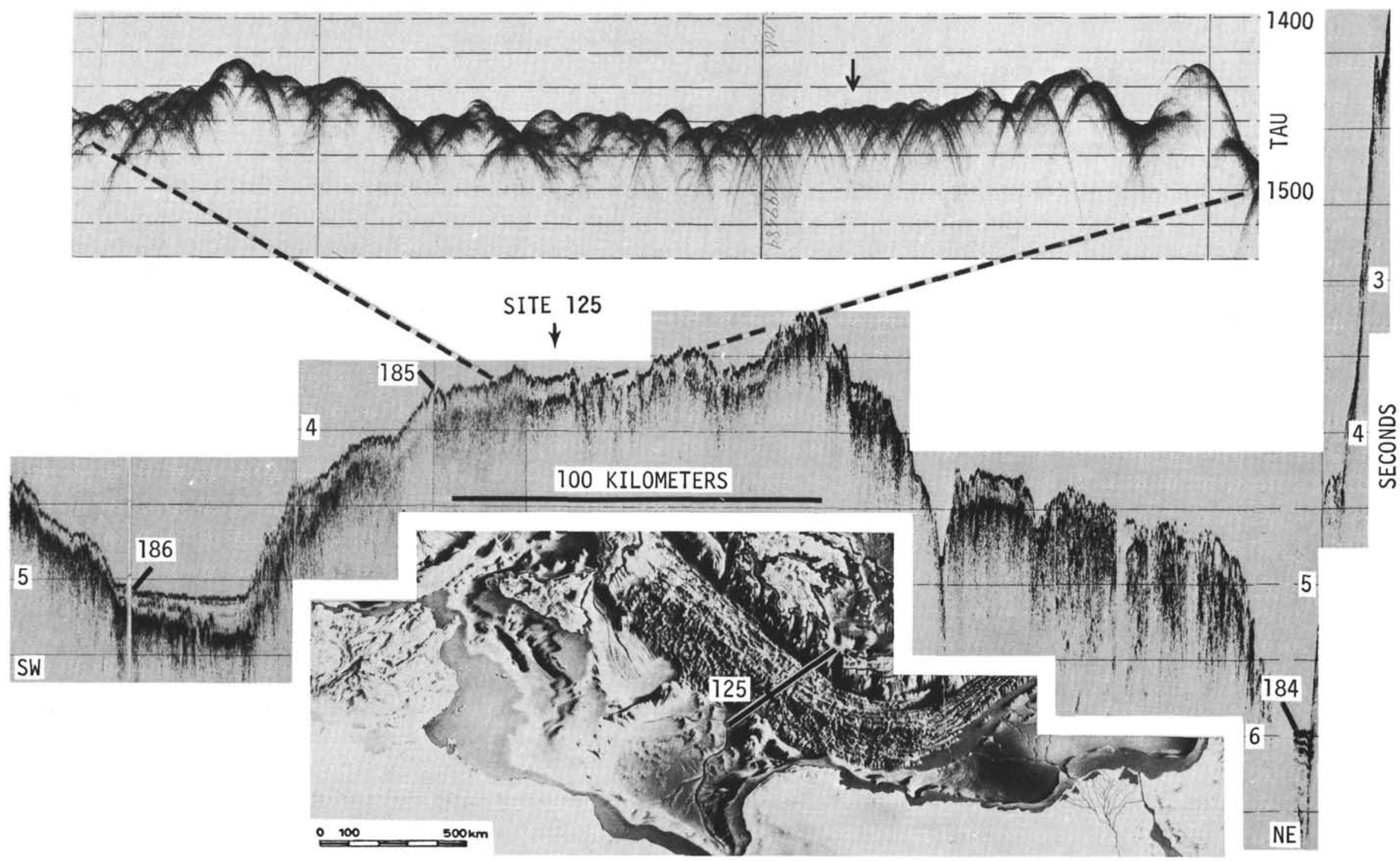

Figure 2. Geological setting of Site 125 in the Ionian Basin. The drill site is shown on a reflection profile across the Mediterranean Ridge. The target was selected in a pelagic environment where the thickness of sediment above Horizon M is uniform, and where the small scale hummocky tecture of the ridge is subdued (see upper insert of a $12 \mathrm{kHz}$ echogram across the site location). Vertical scale in seconds; 1 tau $=1 / 400$ th second. The numbers 184, 185, 186 refer to piston cores of Cruise 9 of the Robert D. Conrad, Lamont-Doherty Geological Observatory. 
Likewise, the uppermost part of the section at Site 132 was not recovered. In this case, however - based on a lithological comparison with nearby piston core RC9-195 only about $120 \mathrm{~cm}$ of the topmost part of the section at Site 132 seem to be missing.

Since in each case the part of the section not recovered in the Deep Sea Drilling cores can be overlapped onto existing stratigraphic successions, we feel that the DSDP cores at Sites 125 and 132, combined with the data from the other sources, may be taken as useful reference sections for the Quaternary of the eastern and central Mediterranean.

\section{THE PLIOCENE-PLEISTOCENE BOUNDARY}

The Pliocene-Pleistocene boundary, as officially defined at the 18th International Geological Congress of 1948 in London, is placed at the base of Calabrian stage, which was established by Gignoux $(1910,1913)$ on sections in southern Italy.

Paleontologically, the boundary is marked by the first appearance of northern immigrants such as the pelecypod Arctica islandica (Linné) and the benthic foraminifer Hyalinea baltica (Schroeter). Both of these fossils are considered to be indicators of cold water. Their presence in the Mediterranean Sea was explained to be the result of a climatic change from temperate to cold conditions due to the onset of the great continental glaciations of the Pleistocene.

$A$. islandica is limited to littoral sandy facies while the depth range of $H$. baltica in the Mediterranean Sea and Atlantic Ocean today is about 60 to 1000 meters; its distribution in older sediments seems to be consistent with its modern depth range. On account of the wider distribution of $H$. baltica, many researchers have suggested that the Pliocene-Pleistocene boundary be defined by the first appearance of this species (Ruggieri and Selli, 1950).

Hyalinea baltica was not found in any of the 220 samples investigated from the Quaternary of Site 132, some 500 kilometers from the classical Pliocene-Pleistocene area of the Crotone Basin. Neither was it found in any of the DSDP drill sites in the Ionian and Levantine basins. The only Mediterranean sites where Hyalinea baltica was seen are Sites 121 (Alboran Basin - water depth $1200 \mathrm{~m}$ ) and 122 (Valencia Channel - water depth $2700 \mathrm{~m}$ ). In the Valencia Channel this species is associated with other benthic foraminifera (i.e. Amphistegina lessonii, Elphidium spp.) indicative of reworking from shallow, nearshore environments. These findings reveal that Hyalinea baltica is generally not present in the Mediterranean as an autochthonous form in deep-water strata. It therefore cannot be used as a marker for the boundary in these sediments; moreover, records of this species from the deep basins (see Todd, 1958, piston cores 06, 08, 010, 011, 205, 209, 210; Parker, 1958, piston cores $188,192,194$ ) appear to be a result of redeposition from shallower areas.

\section{The Section of Le Castella}

In a study by Emiliani, Mayeda and Selli (1961) of the section at Le Castella, close to Santa Maria di Catanzaro, one of the Gignoux type sections, the Pliocene-Pleistocene boundary was clearly marked by the first appearance of $H$. baltica. The sediments contain a rich pelagic fauna, and the estimated environment of deposition, on the basis of benthic foraminifera, was considered to be bathyal. Furthermore, oxygen isotopic analyses made on the foraminifera and mollusc shells revealed several temperature oscillations. As a consequence, the section of Le Castella was proposed as the type section for the PliocenePleistocene boundary at the 7 th INQUA Congress in Denver, Colorado, in 1965.

Our concern is that in areas far from the Mediterranean, or in deep pelagic sediments like those drilled at Sites 125 and 132 , where $H$. baltica is lacking, new paleontological criteria on which to base the Pliocene-Pleistocene boundary are very much in need, since those defined in the section of Le Castella are inapplicable.

Recent investigations of planktonic foraminifera and nannofossils have revealed some biostratigraphic events which apparently are generally suitable for morldwide correlations and which are apparently not climatically affected.

\section{Correlation with the Boundary in Deep-Sea Sediments}

With their attention turned to the slowly accumulating pelagic sediments of the deep sea, as the most concise and complete record of the Quaternary, Ericson, Ewing and Wollin (1964) constructed what they believed to be a complete section of the Quaternary by piecing together and correlating overlapping sequences of many piston cores from the North Atlantic and Caribbean. Their reconstruction was based on climatic curves (determined from the relative number of planktonic foraminifera of cold- and warm-water affinities) and changes in the coiling direction of Globorotalia truncatulinoides. They established the following criteria for defining the Pliocene-Pleistocene boundary in deep-sea sediments (Ericson, Ewing, and Wollin, 1963): (a) extinction of Discoasteridae; (b) extinction of Globigerinoides sacculifera fistulosa at the boundary; (c) appearance of Globorotalia truncatulinoides in abundance above the boundary; (d) change in the direction of coiling of the members of the Globorotalia menardii complex from 95 per cent right coiling below, to 95 per cent left coiling above; and (e) a marked increase in the size and wall thickness of the tests of members of the G. menardii complex above the boundary.

About at the same time researchers studying equatorial Pacific Cores discovered a useful biostratigraphic datum to be the extinction horizon of the radiolarian Pterocanium prismatium (Riedel et al., 1963).

It was not until Banner and Blow (1965) found in the stratotype of Santa Maria di Catanzaro, a transition from $G$. tosaensis to $G$. truncatulinoides near the base of the Calabrian, that for the first time a link appeared between the deep-sea record and the type Pliocene-Pleistocene boundary in Italy. Glass et al. (1967), working on North Atlantic and Pacific cores discovered that the boundary of Ericson, Ewing and Wollin lay near the base of the Olduvai magnetic event $(\approx 1.8$ million years) coincident with the $P$. prismatium extinction horizon, previously miscorrelated by Harrison and Funnell (1964) with the Matuyama-Brunhes boundary. 
Berggren et al. (1967) working independently on North Atlantic cores, located the $G$. tosaensis to $G$. truncatulinoides transition within the Olduvai event and concluded that this biostratigraphic event was probably the most satisfactory for marking the boundary in deep-sea cores. At Le Castella this transition is not far from the first appearance of $\mathrm{H}$. baltica. Furthermore, Hay and Boudreaux (1968) have located the base of the Gephyrocapsa caribbeanica Zone (nannofossil) directly above the extinction level of Discoasteridae in deep-sea Caribbean sections and have noted that this stratigraphic horizon correlates well with the first appearance of $H$. baltica in Italy.

Other biostratigraphic datums of ecological type, such as that concerning the coiling direction of Globigerina pachyderma are probably less useful than those based on evolutionary changes. Bandy (1960) thought the change in coiling direction of Globigerina pachyderma (Ehrenberg) might indicate climatic change from warm to cold near the Pliocene-Pleistocene boundary, but it seems that this change has taken place at different times in different areas. At Le Castella and Santa Maria di Catanzaro, for example, G. pachyderma is predominantly dextrally coiled below and above the appearance of $H$. baltica (Bandy and Wilcoxon, 1970), whereas in northern Italy, at the Santerno section, $G$. pachyderma is rare and mostly dextrally coiled in the Upper Pliocene and becomes abundant and mostly sinistrally coiled a few tens of meters below the appearance of $\mathrm{H}$. baltica. At Site 125 Globigerina pachyderma is rare and always right-coiled.

The concept of many researchers has been to relate the Pliocene-Pleistocene boundary with a major paleoclimatic change from temperate to cold due to the beginning of great glaciations. However, isotopic analyses on foraminifera for Le Castella made by Emiliani, Mayeda and Selli (1961) demonstrate that there was no major cooling at the base of the Calabrian type section.

Paleoecological data supplied by planktonic foraminifera, which are better temperature indicators than the benthonic, gave similar results. These were supported by studies on coccoliths across the deep-sea boundary (McIntyre et al., 1967).

The existence of a preglacial period ${ }^{1}$ in Lower Pleistocene followed by a glacial Upper Pleistocene has been suggested for the European region by many investigators (Emiliani, 1955, Emiliani, 1955, 1961, 1966; Selli, 1967; Ryan, in press). The data obtained from Sites 125 , in the Ionian Basin, and 132, in the Tyrrhenian Basin, confirm this interpretation.

\section{The Pliocene-Pleistocene Boundary at Site $\mathbf{1 2 5}$}

The Quaternary sediments recovered at Site 125 are nanno-foraminiferal oozes of pure pelagic type. The benthonic foraminifera are extremely rare and among these $\mathrm{H}$. baltica is missing altogether. The Pliocene-Pleistocene boundary is contained in Section 5 of Core 4 , and is

\footnotetext{
${ }^{1}$ Reference is made here only to the European glacial periods, and not to general climatic deterioration which commenced much earlier at high altitudes.
}

biostratigraphically defined by the first occurrence of Globorotalia truncatulinoides. The extinction of Discoaster brouweri occurs in Core 4, Section 2.

It is noted that the paleomagnetic measurements (reported in Chapters 19 and 47 of this volume) on Core 4 show a change from a negative NRM inclination at the top of Section 6 to a positive inclination near the base of Section 5 . If this apparent change in polarity represents an accurate remanent recording of the earth's magnetic field, we would choose to correlate this change with the base of the Olduvai normal event in the Matuyama reversed epoch. Such a correlation is in ideal agreement with the assignment by both Berggren et al. (1967) and Glass et al. (1967) of the first evolutionary appearance of Globorotalia truncatulinoides just above the base of the Olduvai event (approximately $1.85 \mathrm{my}-$ Foster and Opdyke, 1970). Average sedimentation rates for the Quaternary at Site 125 compute to approximately 2.5 centimeters per 1000 years. $^{2}$

\section{The Pliocene-Pleistocene Boundary at Site 132}

The Pliocene-Pleistocene boundary is located at Site 132 in Section 5 of Core 8 in coincidence with the extinction horizon of Discoaster brouweri. The first evolutionary appearance of Globorotalia truncatulinoides, evolving from G. tosaensis, which was proposed and adopted as a biostratigraphic event characterizing the PliocenePleistocene boundary (Blow, 1969, inter alia) could not be used here because both taxa are absent in the interval near the extinction horizon of Discoaster brouweri although they have been recorded respectively in samples above and below this level.

The lack of keeled Globorotalia in the sediments of the latest Pliocene and earliest Pleistocene at Site 132 is here considered as ecologically controlled. The ecologic factor is not necessarily related to the temperature of the surface water mass of the photic zone since $G$. truncatulinoides is a subsurface dweller (depth habitat 200-300 meters according to Ruddiman, Tolerlund and Bé, 1970). A possible control related to changes in the depth of the maximum gradient of the thermocline is suggested.

The paleomagnetic measurements are of some help in confirming the level of the boundary, because four reversal datums can be picked from the remanent inclination measurements. ${ }^{3}$ These levels, shown in Figure 3, include:

1) The Brunhes-Matuyama boundary in Section 4 of Core 3 ( 23 meters below bottom),

2) The Jaramillo event in the Sections 3 and 4 of Core 4 (30.5 to 32 meters),

3) The top of the Olduvai event (shown most clearly in the NRM plot of Figure 2, Chapter 19) at the bottom of Section 6 of Core 7 (62.5 meters), and

4) The Matuyama-Gauss boundary in the lower part of Section 2 of Core 11 ( 92 meters).

If we assign the latest chronology of Foster and Opdyke (1970) to the magnetic markers, it is possible to interpolate

\footnotetext{
${ }^{2}$ Assuming a missing upper section of $\approx 400,000$ years, and a cored interval of 34 meters of Quaternary.

${ }^{3}$ See Chapter 19 of this volume for a presentation and discussion of the paleomagnetic data.
} 
(Figure 3) the base of the Olduvai event to a level in the Tyrrhenian sediment column. It is of interest to note that this level ( 68.5 meters) falls only one core section above the Discoaster brouweri extinction level and thus sheds confidence on the paleontological criterion used to identify time-synchronous horizons in the Mediterranean deep-sea cores. The magnetic stratigraphy allows a mean sedimentation rate of $\approx 3.5 \mathrm{~cm} / 10^{3}$ to be calculated for the later part of the Quaternary in the sediment column of the central Tyrrhenian Basin.

\section{PROCEDURES}

Investigations devoted to deciphering the paleoclimatic record of the Quaternary generally are based on the occurrence and (relative) abundance of selected species of planktonic foraminifera, used as climatic indicators. The paleoclimatic deductions are supported by the distribution of the living taxa in the water column of the present-day seas. Though some doubts as to the validity of the method have been recently expressed (see for instance, Boltovskoy, 1969; Cifelli, unpublished), it is widely accepted. The method implies long and time-consuming countings of hundreds of foraminiferal specimens for each sample of sediment investigated.

Because of the shortage of time and the great number of samples to process in the two wells cored continuously, this classical method of work was not applied for the initial core description.

The semi-quantitative method described below is new: it was tested during the cruise and proved to be successful and suitable.

Analytical work on the 220 samples investigated from Site 132 was done at the University of Naples by G. Ciampo, M. Moncharmont Zei, and R. Scorziello. The 185 samples from Site 125 were studied by M. A. Chierici, S. D'Onofrio, and M. B. Cita. The methods and graphical procedures used for the paleoclimatic evaluations by each group have not been exactly the same. The two sites are discussed in a single chapter for the purpose of a more concise presentation; however, the differences in the two studies will be apparent. This design has been with purpose in order to help us evaluate our scientific methodology.

\section{Site 132 Procedures}

With 220 samples spaced over an interval of 70 meters, it was possible to examine at Site 132, intervals of sedimentation with a duration of less than ten thousand years.

The work undertaken in analysis of Site 132 samples was oriented toward procedures which would facilitate the analysis of faunal diversity and aid in rapid recognition of faunal assemblages. No precise countings of individual taxa were undertaken. Instead, only visual estimates of the relative abundance of the different taxa have. been attempted, and in this fashion five classes have been delineated.
very rare
rare
common
(1-3 specimens)
(4-10 specimens)
abundant
(11-30 specimens)
very abundant

The approach toward obtaining a measure of faunal diversity was shared with that of Site 125 . The entire $>105 \mu$ fraction obtained from about $5 \mathrm{cc}$ of wet sediment was examined. All the species, even those in very minor abundances, were noted. The following parameters are graphically illustrated in Figure 4:

(a) An inferred paleo-climate curve.

(b) A curve of faunal diversity (i.e. number of species recognized).

(c) A curve of faunal abundance (scaled into four classes based on volume ratios).

Curve (a) is based on the occurrence and relative abundance (as visually estimated) of the species listed below.

1) Cold-water indicators: Globigerina bulloides d'Orbigny, Globigerina quinqueloba Natland, Globigerina pachyderma (Ehrenberg), and Globorotalia scitula (Brady).

2) Temperate-water indicator: Globorotalia inflata (d'Orbigny).

3) Warm-water indicators: Orbulina universa d'Orbigny, Hastigerina siphonifera (d'Orbigny), Globorotalia truncatulinoides (d'Orbigny), Globigerinoides ruber (d'Orbigny), and Globigerinoides sacculifer (Brady).

Species listed in category 1 are generally present in all the samples investigated and become dominant in cold periods. Globorotalia inflata, is not particularly sensitive to temperature, as indicated by its distribution in plankton tows in both the Atlantic and Pacific oceans. It is present in most of the samples investigated. It is absent only in the very coldest intervals. Species listed in category 3 are the most temperature-sensitive and are lacking in the cold intervals. Their occurrence and relative abundance is essential in order to classify an assemblage as temperate, temperate-warm, or warm-temperate.

Other temperature-sensitive species of tropical to subtropical habitat (Hastigerina pelagica, Globigerina digitata and/or G. praedigitata, and Globigerinoides conglobatus) were seldom found in the cores and were not used for construction of the inferred paleoclimatic curve. They are plotted independently in Figure 4 and are used as a cross-check indication of the warm intervals.

Curves (a), (b), and (c) in Figure 4 were constructed independently, as they are based on different parameters. A positive correlation exists among them, in levels of biogenic sediment. No correlation, or sometimes a negative correlation, is found in levels rich in volcanic material which may be locally poor in organogenic content.

\section{Site 125 Procedures}

The differences between the procedures used for Site 125 and those used in the investigation of the Site 132 samples are as follows:

1) The sediment fraction considered is greater than 63 microns (greater than 105 microns at Site 132).

2) The faunal abundance is expressed as a weight percentage of the sediment fraction greater than 63 microns versus the entire (dry) sediment. For Site 132, the curve of faunal abundance was based on an estimate of the volume of the sediment fraction greater than 105 microns for the entirely organogenic fraction or, alternatively, on the 


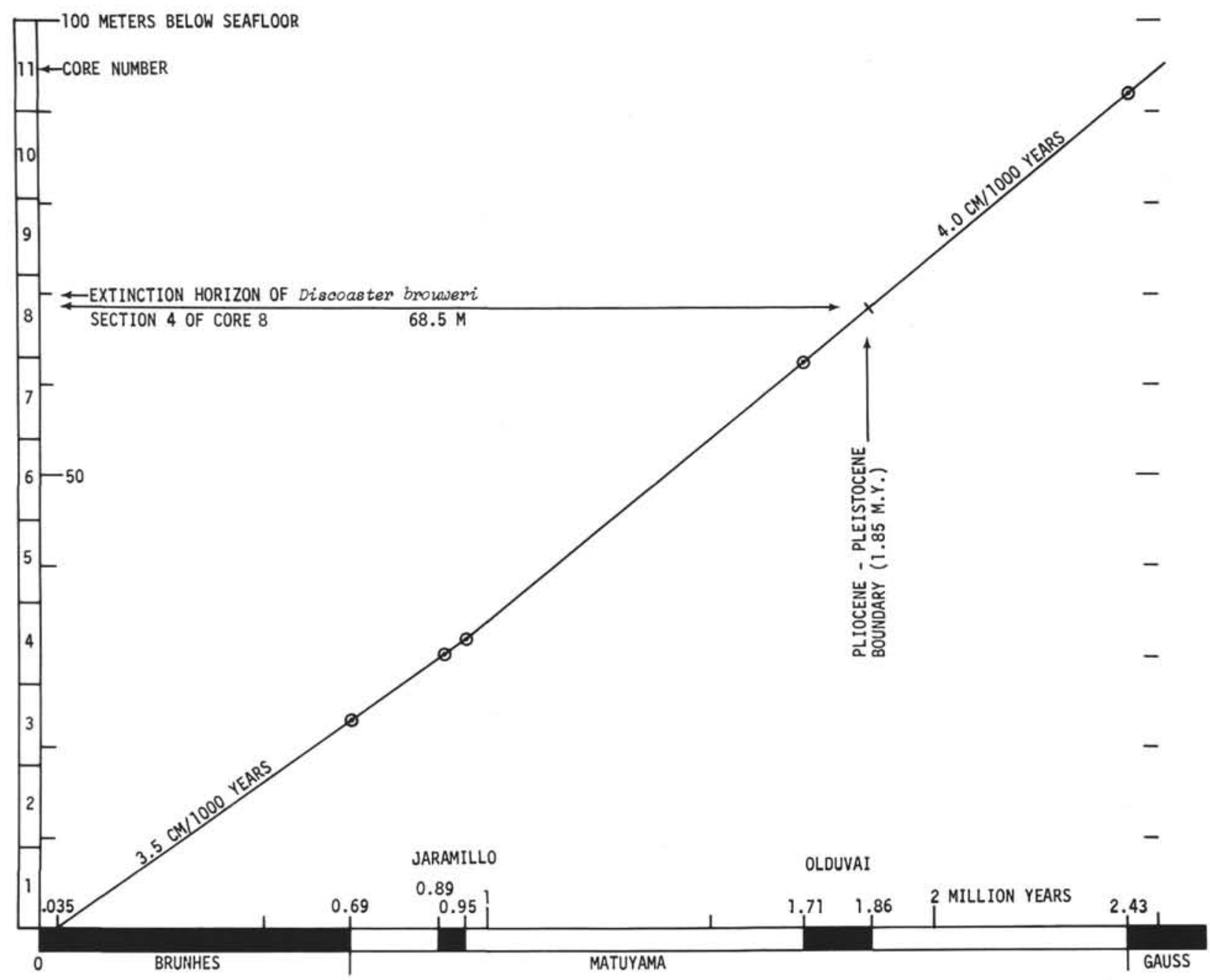

Figure 3. Paleomagnetic chronology of Site 132. The magnetic reversal datums identified in the DSDP sedimentary sections include the Brunhes-Matuyama boundary, the Jaramillo event, the top of the Olduvai event and the Matuyama-Gauss boundary. The paleomagnetic chronology shown is after Foster and Opdyke (1970). The base of the Olduvai is interpolated by a straight line fit between the 1.71 and the 2.43 my datums, and places the inferred Pliocene-Pleistocene boundary $(1.85 \mathrm{my})$ within one meter of the Discoaster brouweri extinction horizon.

estimated faunal abundance in the fractions rich in volcanic material.

3) The inferred paleoclimatic curve for Site 125 shown in Figure 5 was built with the same criteria as used for Site 132. However, instead of being plotted separately, Hastigerina pelagica, Globigerina digitata, G. praedigitata and Globigerinoides conglobatus have been considered along with Orbulina universa, Hastigerina siphonifera, Globorotalia truncatulinoides, Globigerinoides ruber and $G$. sacculifer as warm-water indicators for the purpose of an overall evaluation.

\section{Special Investigations on Selected Species}

In order to evaluate the (inferred) climatic curve, which is based on the occurrence of characteristic associations and on the faunal diversity, some quantitative investigations on selected samples from Site 125 (Cores 1 and 2, and Section 1 of Core 3) were carried out by one of us (S.d'O.). Procedures included the following:
1) A quantity of planktonic foraminifers exceeding 300 units has been considered.

2) All specimens comprising the above listed taxa have been counted; also included were the juvenile specimens that were clearly recognizable.

3) For representatives of Globigerina pachyderma and Globorotalia truncatulinoides left- and right-coiling specimens have been plotted separately.

4) The percentages obtained were calculated by making the sum of specimens belonging to the four taxa under consideration equal to 100 per cent. Specimens belonging to taxa other than those listed above have thus been disregarded in tabulating the percentages.

The data obtained from the sixty samples investigated are plotted in graphical form in Figure 6. A few comments are added here.

1) The frequency curves of Globigerina pachyderma and Globigerinoides ruber always have opposite trends (Figure 6). This is true in particular for Core 1, which contains several layers of black organic-rich (sapropelitic) mud. 


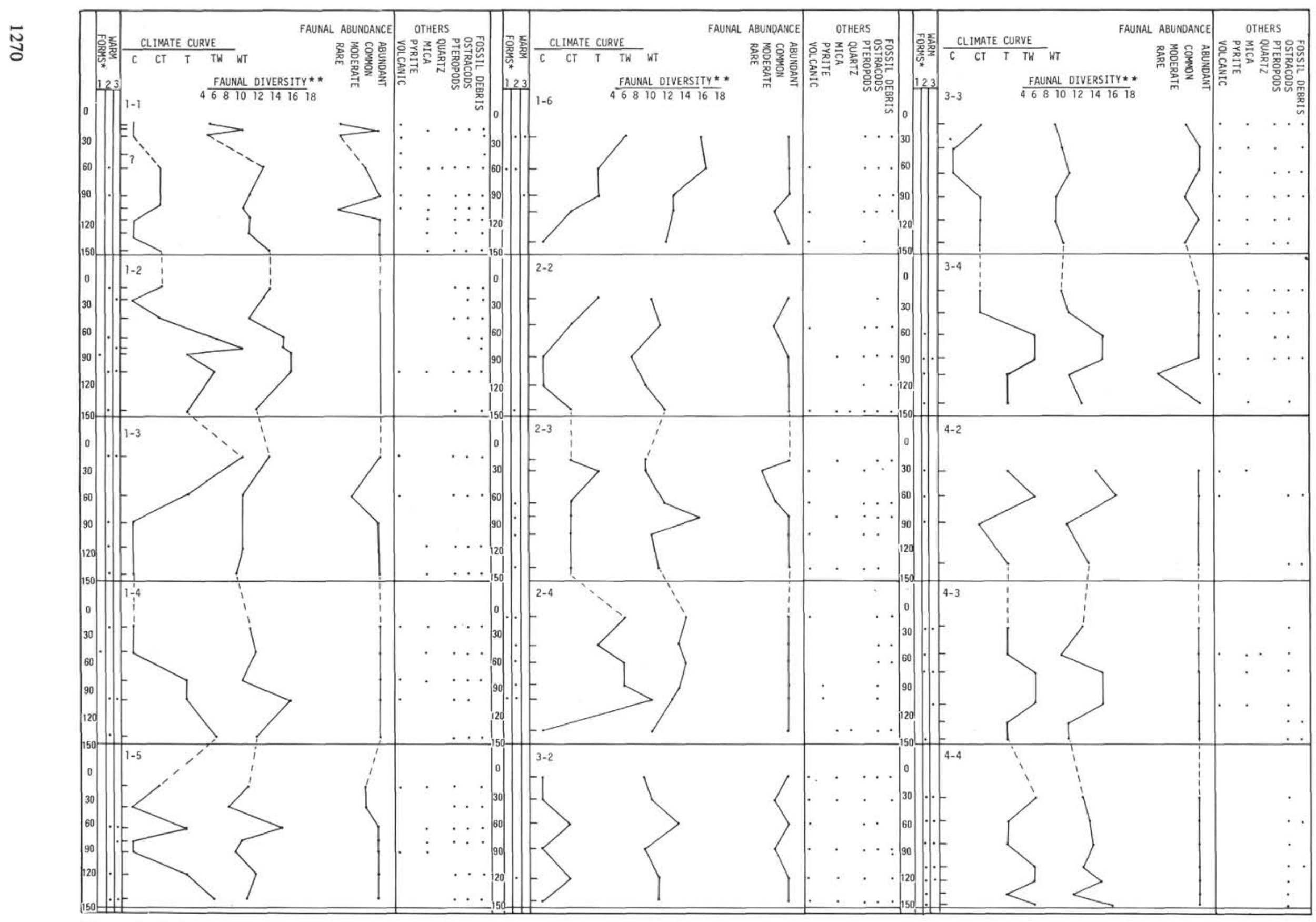

Figure 4. Inferred paleo-climate curves for the Quaternary sections of Site 132, Tyrrhenian Basin. For a discussion of the curves, see text. The numbers next to the core column indicate the sample locations in centimeters for the various sections of the eight Quaternary cores, cut continuously. 


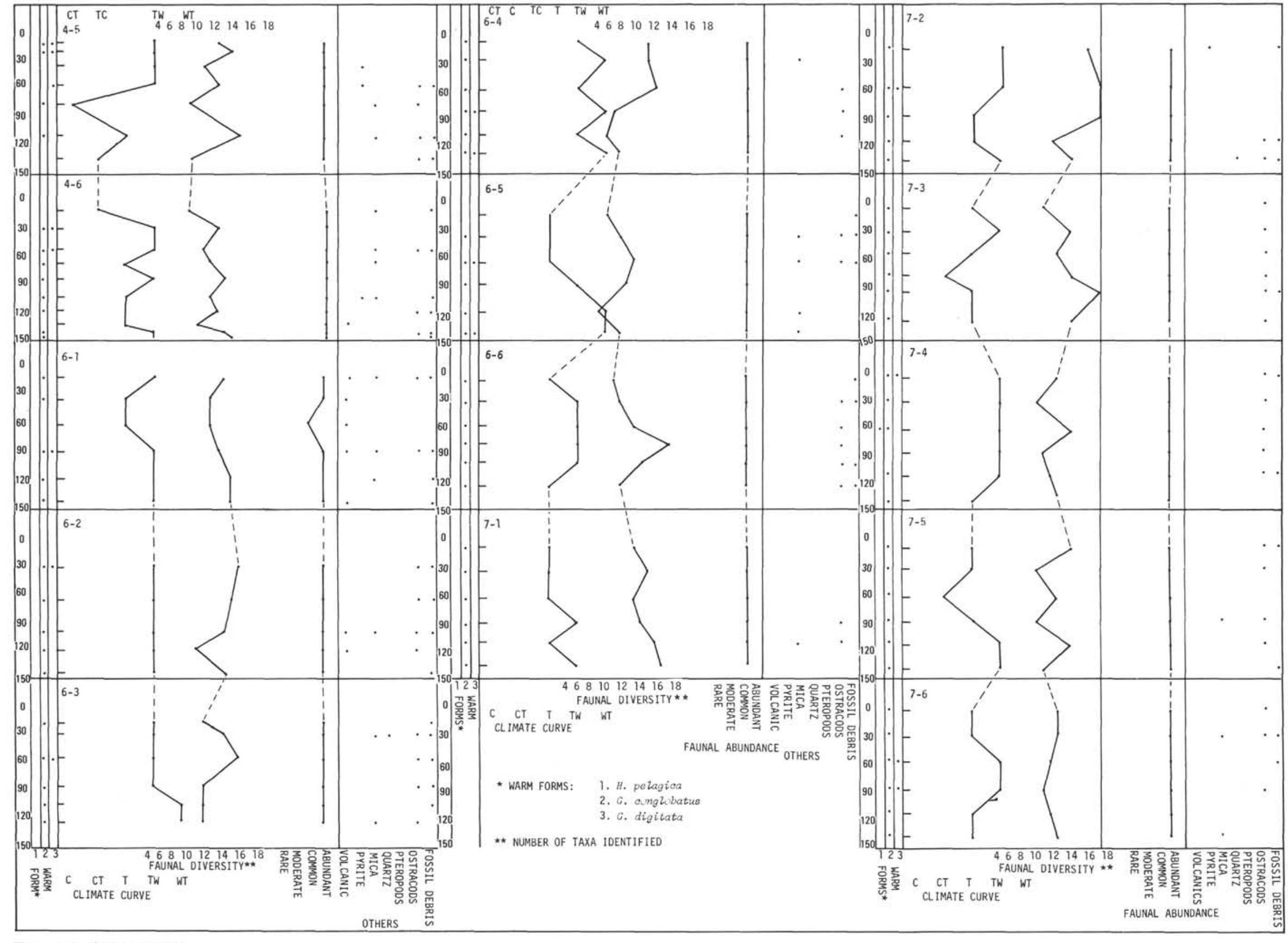

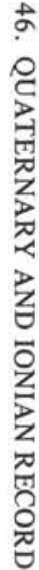




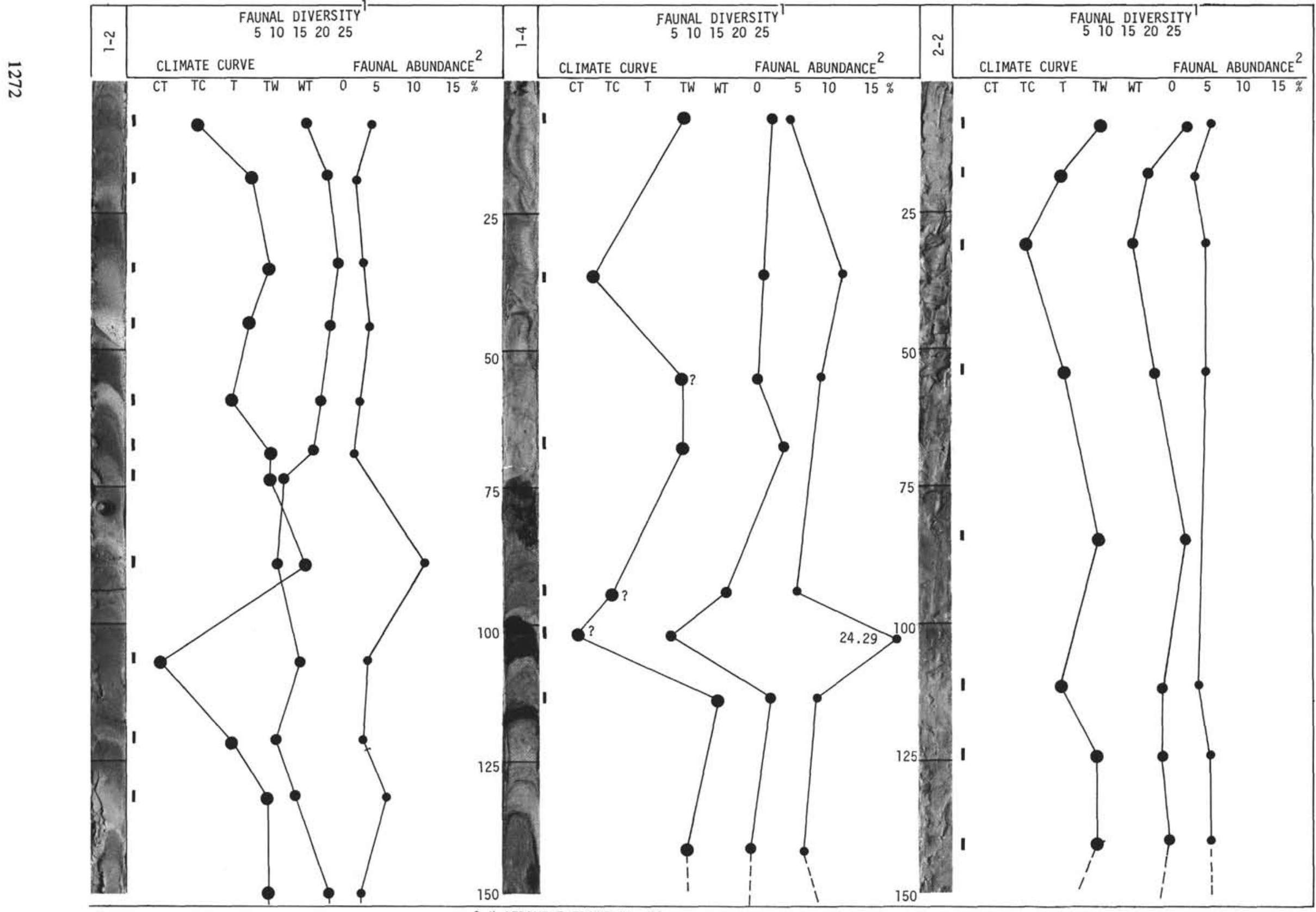

1 NUMBER OF PLANKTONIC SPECIES

$2 \%$ SEDIMENT FRACTION $>63$

Figure 5. Inferred paleoclimatic curves for the Quaternary of Site 125, Ionian Basin. The three curves are based on independent criteria: analysis of faunal assemblages, faunal diversity (number of taxa present), and faunal abundance (weight percentage of sediment fraction greater than 63 microns versus the entire dry sediment sample). The core photographs illustrate the different lithologic units (sapropels, tephra layers, etc.) and reveal the physical disturbance introduced in the coring process. The dark bars next to the photographs indicate sample locations. 


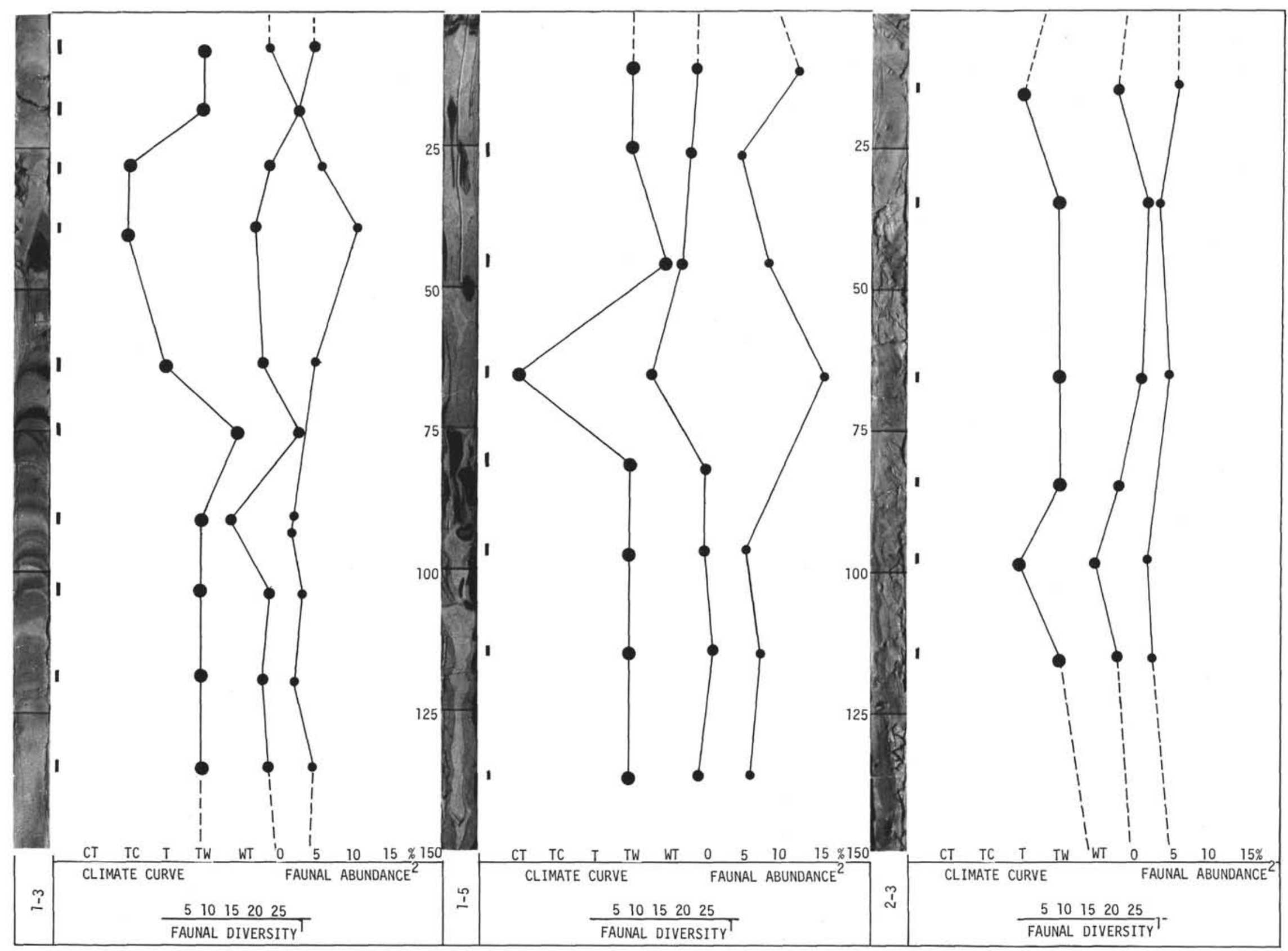




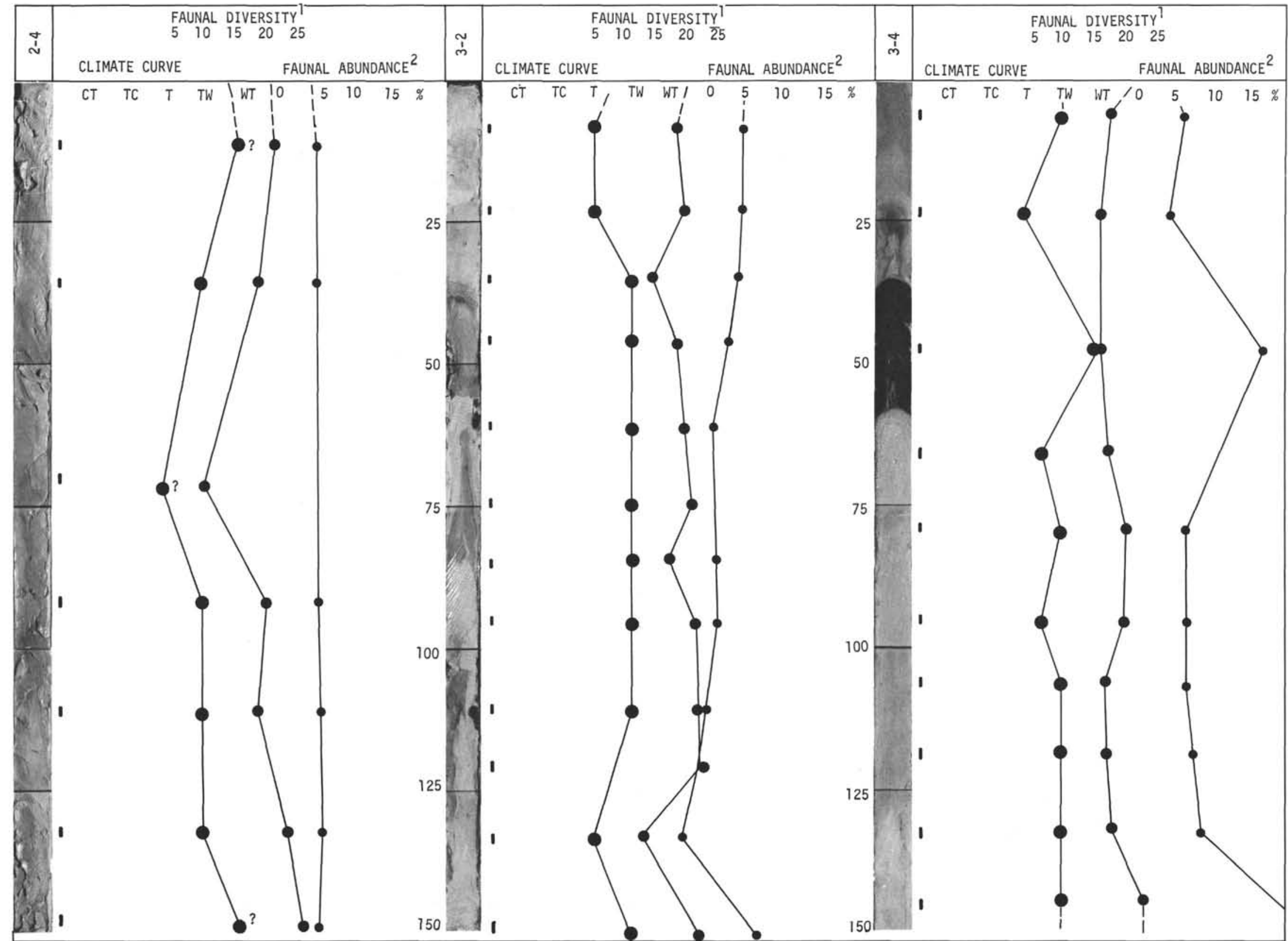

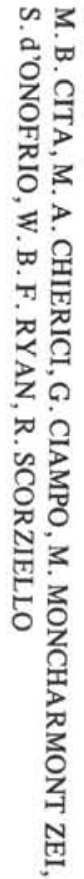

1 NUMBER OF PLANKTONIC SPECIES

2. \% SEDIMENT FRACTION $>63 \mu 3$

Figure 5. (Continued) 


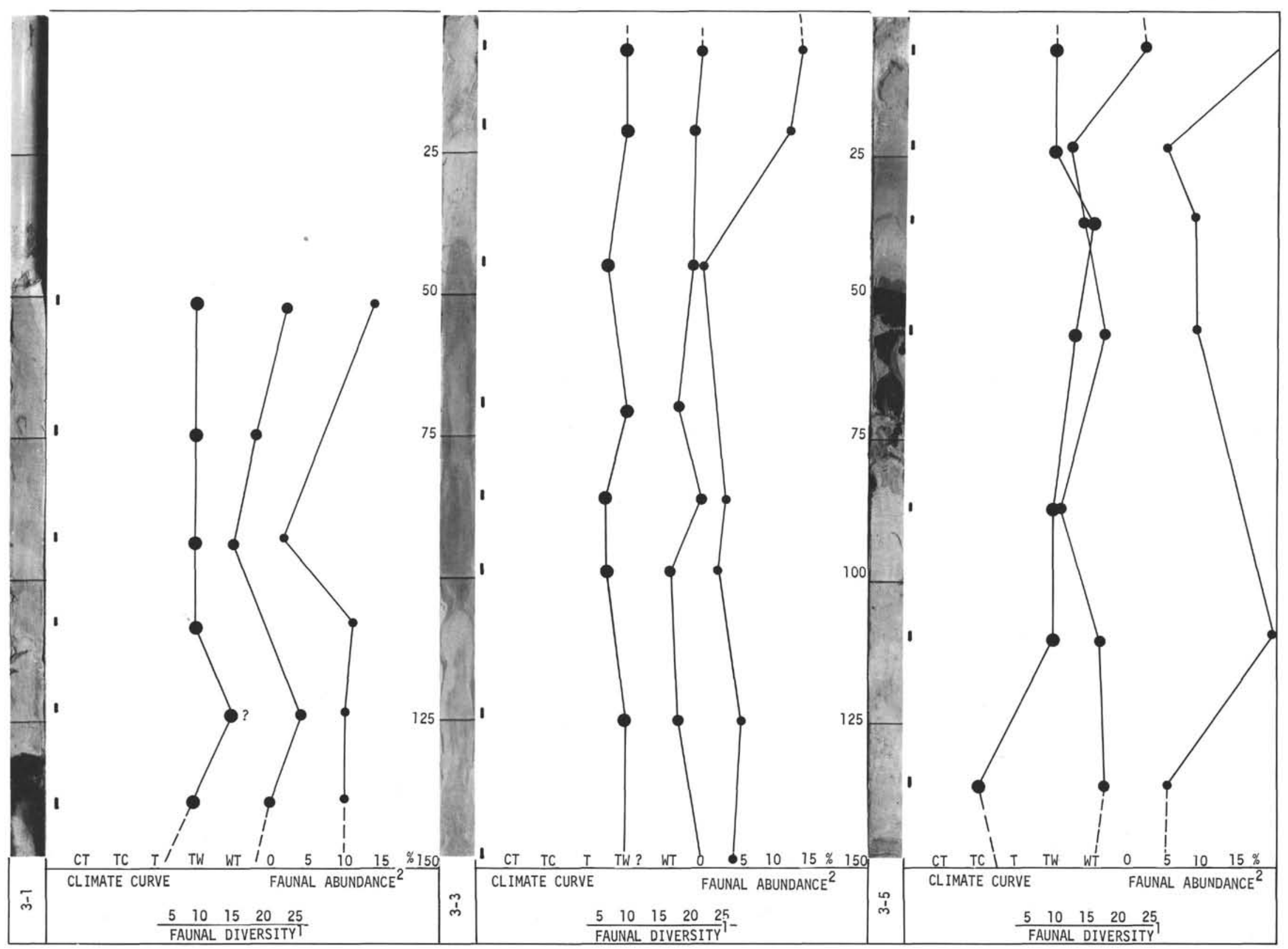




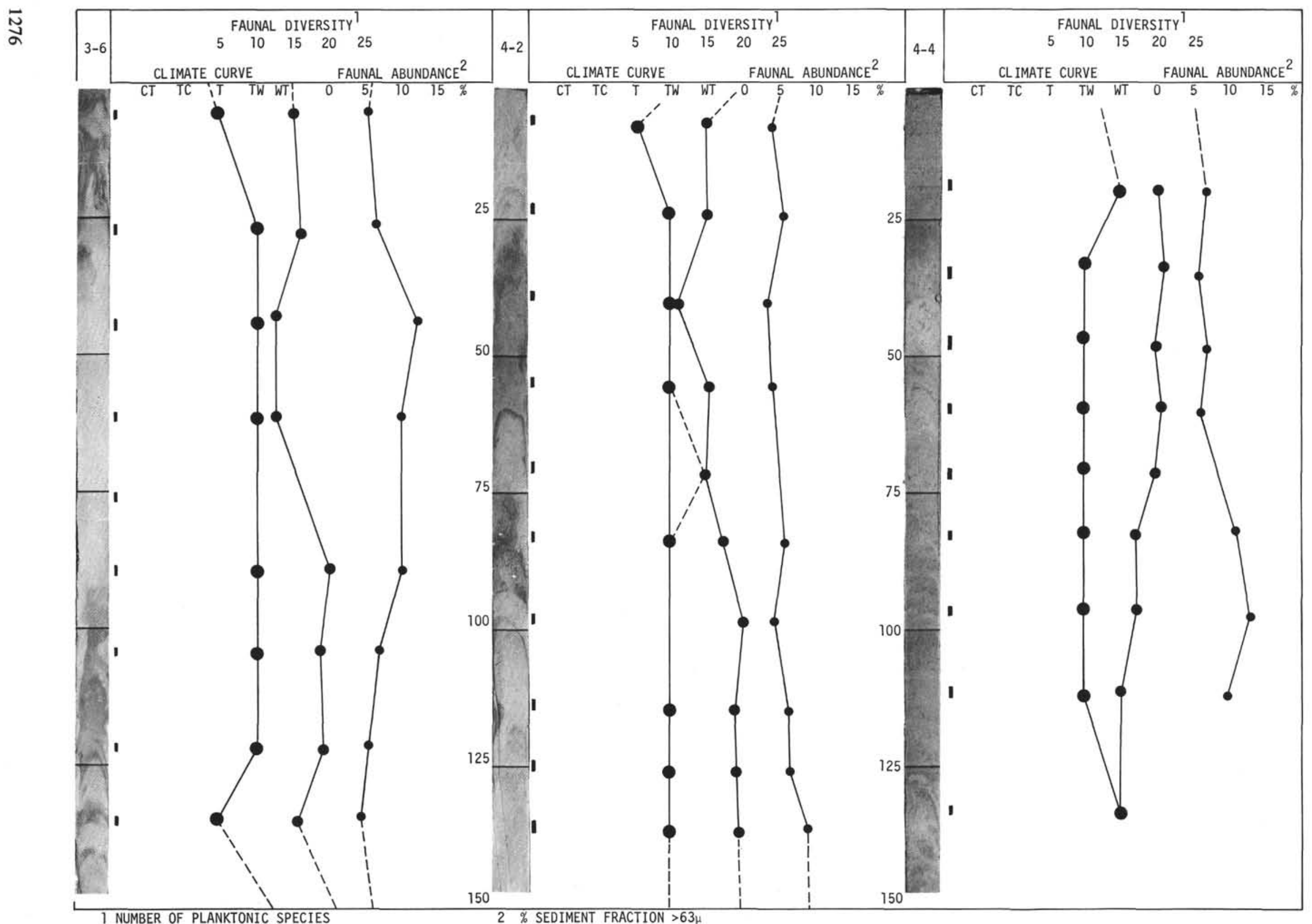

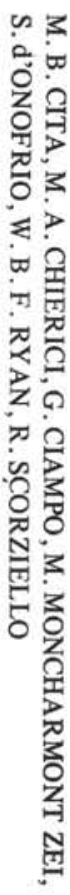

Figure 5. (Continued) 


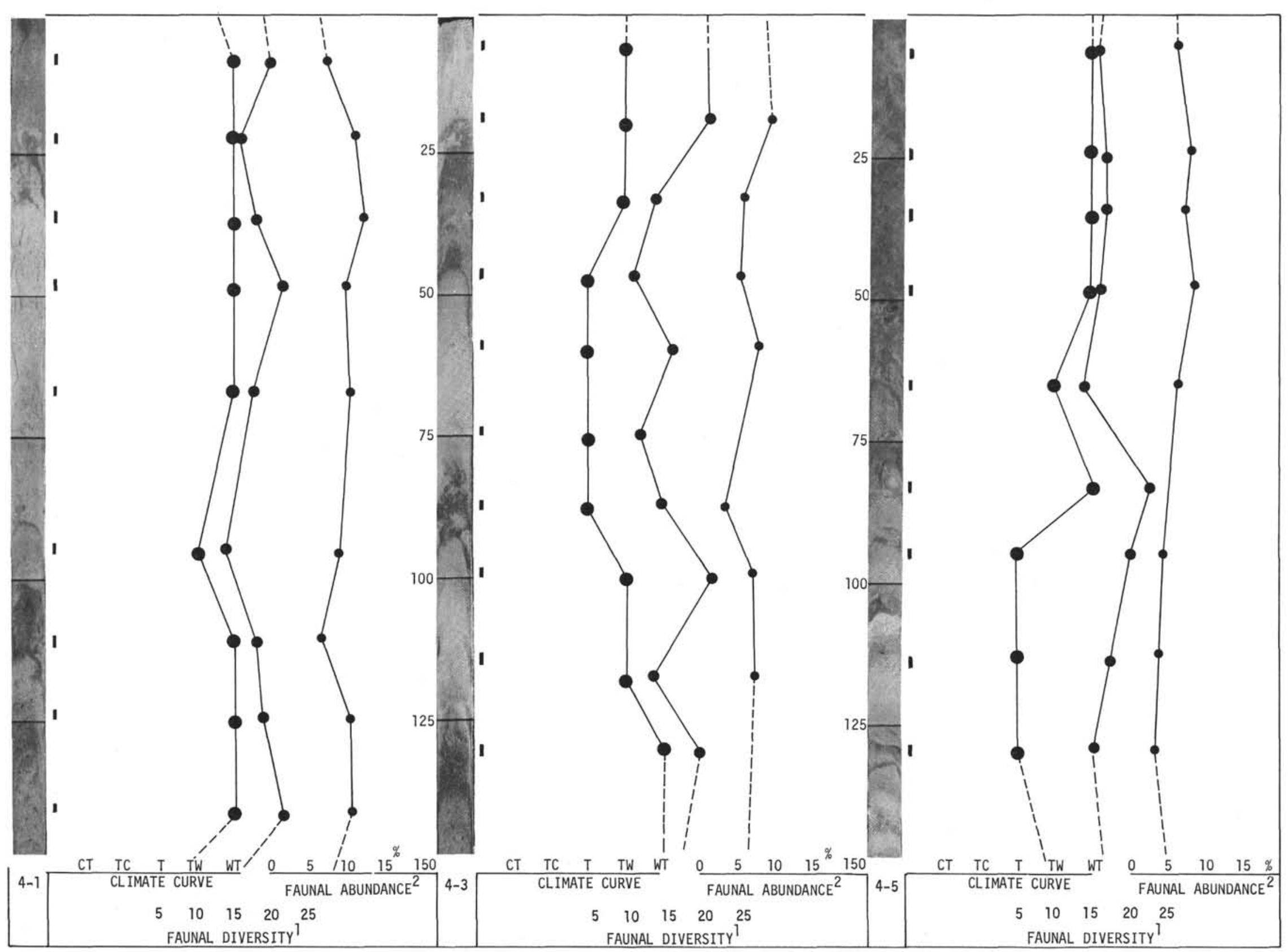


M. B. CITA, M. A. CHIERICI, G. CIAMPO, M. MONCHARMONT ZEI, S. d'ONOFRIO, W.B.F. RYAN, R. SCORZIELLO

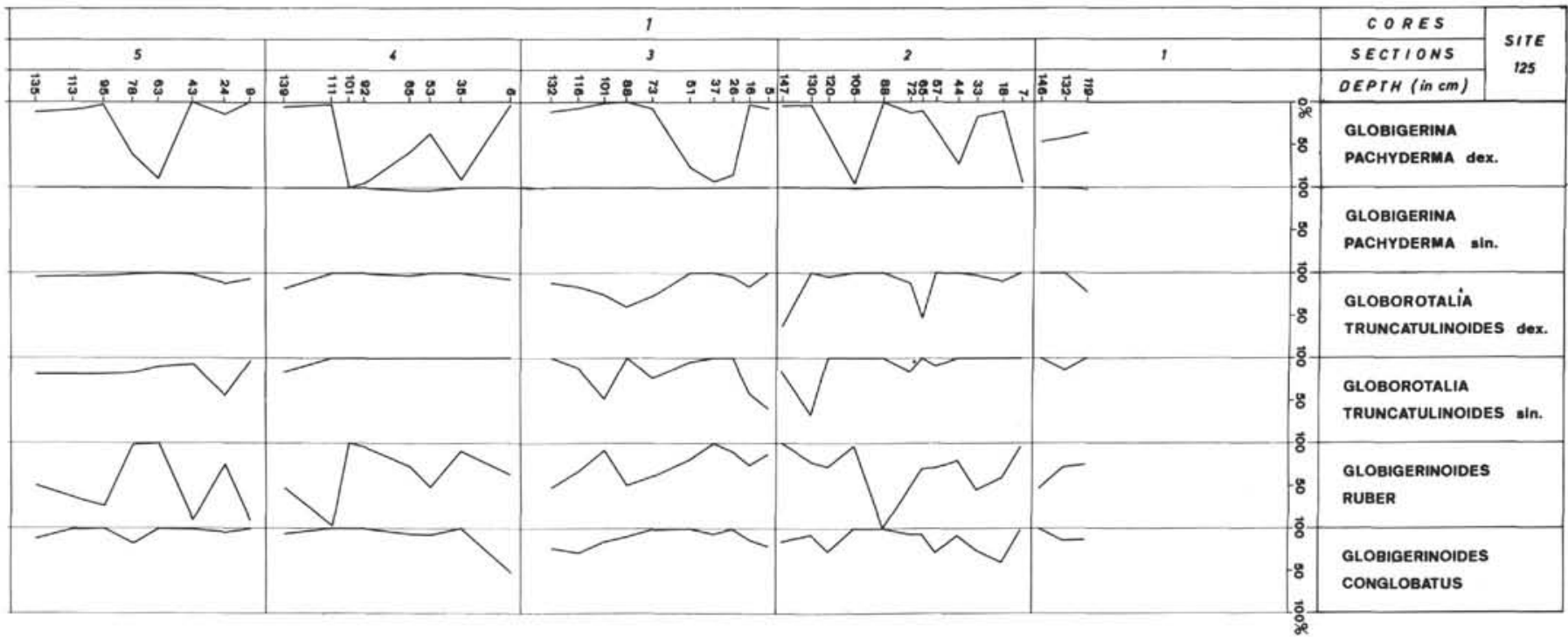

Figure 6. Frequency curves of Globigerina pachyderma (dextral and sinistral), Globorotalia truncatulinoides (dextral and sinistral), Globigerinoides ruber, and $\mathrm{G}$. conglobatus in the samples investigated from Cores 1, 2, and 3, Site 125. For further explanations, see text.

2) Globigerina pachyderma was never dominant in any of the assemblages investigated. The highest percentages recorded are from:

Sample 1-2, 105-107 cm, 96 per cent relative abundance, 30 per cent total fauna.

Sample $1-4,101-103 \mathrm{~cm}, 100$ per cent relative abundance, 8 per cent total fauna.

Sample 1.5, 63-65 cm, 90 per cent relative abundance, 8 per cent total fauna.

Sample 2-2, 29-31 cm, 83 per cent relative abundance, 40 per cent total fauna.

3) Globigerina pachyderma is almost always rightcoiling; left-coiling specimens occur rarely and are limited to the coldest intervals.

4) Globorotalia truncatulinoides is dominantly leftcoiling. Further comments on its coiling ratio may be found in a later section (under $G$. truncatulinoides).

5) Globigerinoides conglobatus is present in Core 1 with dominantly small specimens, which have been plotted along with the larger ones. Only Sample 1-2, 147-149 cm shows fully developed tests. The characters which serve to distinguish this species from $G$. gomitulus are the wall structure, intercameral sutures and apertural characters. Large-sized specimens of $G$. conglobatus have been found in great abundance $(79.48 \%$ relative abundance, about $20 \%$ of the total fauna) in a sapropel layer sample $(3-1,138-140$ $\mathrm{cm})$. Similar findings of extremely well-developed and abundant $G$. conglobatus, which have not been studied statistically, are recorded from other levels of Core 3, Site 125 , immediately overlying sapropel layers (such as $3-4,5-7$ $\mathrm{cm} ; 3-5,36-38 \mathrm{~cm}$ ).

\section{THE PLANKTONIC FORAMINIFERA}

The planktonic foraminiferal species and/or subspecies recorded from the Quaternary cores at Sites 132 and 125 are listed in taxonomical order in Tables 1 and 2, respectively, and the range distributions are shown in Figures 7 and 8 . Also, many of the taxa are illustrated in the plates that follow at the end of this chapter. The included photographs, taken with a scanning electron microscope JEOL-I-M2, show details of the wall surface, structure, pores, apertures, and so forth, of the tests.

This preliminary report is essentially devoted to the ecologic evaluation of the stratigraphic record by means of planktonic foraminifera and consequently, is not oriented towards taxonomical problems. However, since the samples were studied by two different research groups, comments are added here in order to clarify each author's approach to some controversial species or groups of taxa further subdivided and variously interpreted.

\section{Discussion of the Site 132 Taxa}

Globigerina digitata Brady and $G$. praedigitata Parker (Plate 1, Figures 1-5), although being closely related, are here considered as discrete taxa. They are distinguished from each other mainly by the radial elongation of the chamber(s). Both of them are present only in the intervals interpreted as temperate-warm to warm-temperate, and they are never abundant, especially $G$. digitata which appears the most temperature-sensitive. They are plotted together in Figure 8.

Globigerina eggeri Rhumbler (Plate 2, Figures 1-4) is never abundant in the Quaternary section of Site 132 and is recorded in about $1 / 3$ of the samples investigated. The distribution of this species is very different in the Quaternary of Site 125, where it represents an important component of the planktonic assemblages in some intervals, especially near the sapropel layers. The different patterns indicate that the ecological factor which controls the abundance of Globigerina eggeri is not dependent solely on temperature, but apparently is related to phenomena which accompanied the periods of stagnation of the eastern Mediterranean. For further details on this species, as well as on its relationships with Globorotalia dutertrei, reference is made to the discussions of Site 125 taxa. 


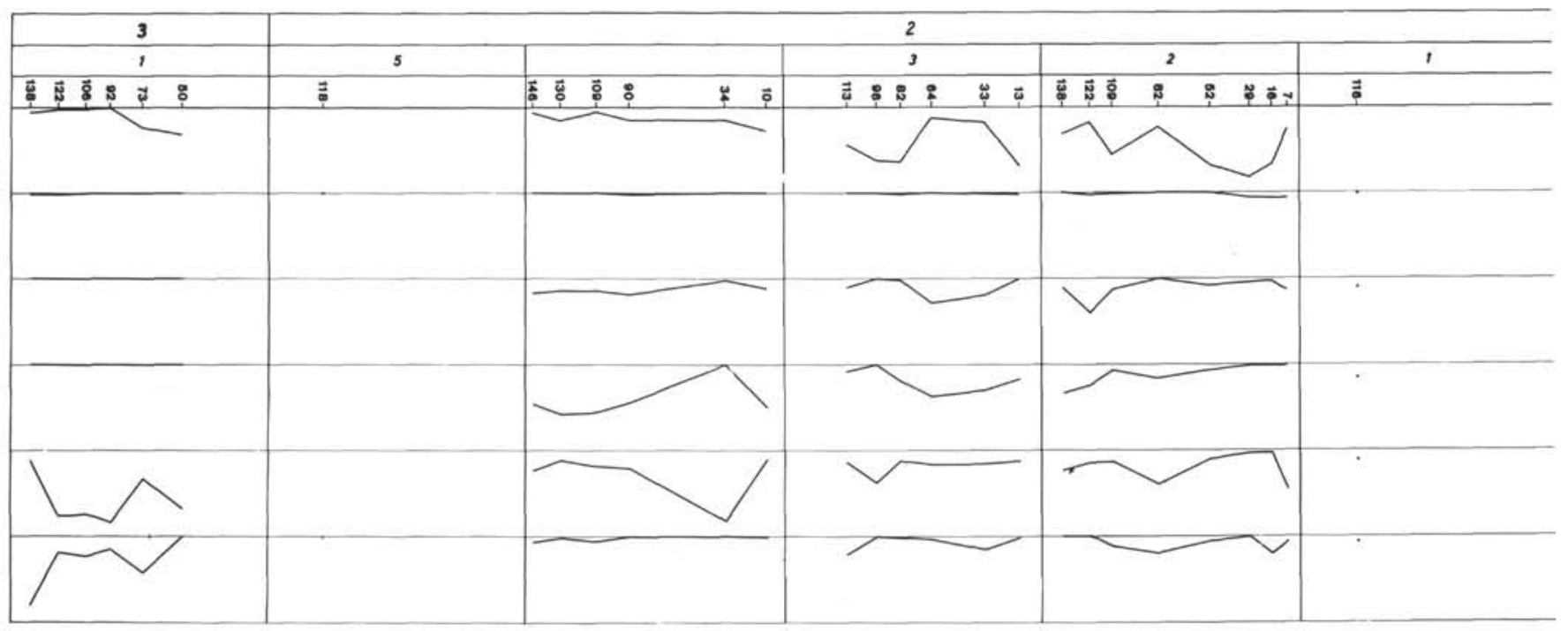

Figure 6. (Continued)

TABLE 1

Planktonic Foraminiferal Species in the Quaternary Sediments of Site 132 - Tyrrhenian Basin

Globigerina bulloides d'Orbigny

Globigerina digitata Brady

Globigerina eggeri Rhumbler

Globigerina falconensis Blow

Globigerina incompta Cifelli

Globigerina pachyderma (Ehrenberg)

Globigerina praedigitata Parker

Globigerina quinqueloba Natland

Globigerinoides conglobatus (Brady)

Globigerinoides elongatus (d'Orbigny)

Globigerinoides fistulosus (Schubert)

Globigerinoides helicinus (d'Orbigny)

Globigerinoides quadrilobatus (d'Orbigny)

Globigerinoides ruber (d'Orbigny)

Globigerinoides sacculifer (Brady)

Globigerinoides trilobus (Reuss)

Globigerinita glutinata (Egger)

Globigerinita uvula (Ehrenberg)

Globorotalia crassaformis (Galloway \& Wissler)

Globorotalia crassaformis viola Blow

Globorotalia inflata (d'Orbigny)

Globorotalia scitula (Brady)

Globorotalia tosaensis Takayanagi \& Saito

Globorotalia truncatulinoides (d'Orbigny)

Hastigerina pelagica (d'Orbigny)

Hastigerina siphonifera (d'Orbigny)

Orbulina bilobata (d'Orbigny)

Orbulina universa d'Orbigny

Sphaeroidinella dehiscens (Parker \& Jones)

Globigerina atlantisae Cifelli and Smith ${ }^{\mathrm{ab}}$

Globigerina bulbosa Finlayb

Globigerina microstoma Cita, Premoli Silva and Rossib

Globigerina rubescens Hofkerb

Globigerinoides tenellus Parker $\mathrm{b}$

Globorotalia acostaensis Blowb

${ }^{a}$ The present authors agree with Cifelli and Smith (1970) on the synonymy of Globigerina radians Egger, as recorded by Parker (1958) in the Mediterranean.

bThese taxa seldom occur and do not appear to be particularly temperature sensitive. They are not included in the range chart of Figure 7.
Globigerina quinqueloba Natland (Plate 3, Figures 1-4) is considered here in a fairly broad sense, and includes the form without a definite umbilical expansion of the lastformed chamber, distinguished by Cifelli and Smith (1970) as $G$. quinqueloba egelida. The two taxa appear to have the same habitat and to give similar response to ecologic changes.

Globigerina incompta Cifelli is considered here as a discrete taxon, although closely related to G. pachyderma. Distinctive characteristics of the former, as compared to the latter, are the slightly higher number of chambers in the last whorl (4-1/2 to 5$)$, the more open aperture, more lobulate equatorial periphery, and the less massive chamber wall. The coiling is always right.

Globigerina pachyderma (Ehrenberg) is present throughout the Quaternary section in different abundances (Plate 4, Figures 1-4). The specimens seldom occur and are most abundant in the coldest intervals investigated. However, they never appear to be dominant. The left-coiling specimens are usually smaller than the right-coiling ones.

Globigerinoides conglobatus (Brady) is one of the most commonly represented species belonging to the genus (Plate 6, Figures 1, 2, 4 and 6; Plate 7, Figures 1 and 2). It is distinguished from G. gomitulus (Seguenza) (Plate 6, Figures 3 , and 5), which also has an overall subspherical shape, by its larger size, thicker wall, deeply depressed intercameral sutures, and more abundant supplementary apertures.

Globigerinoides conglobatus is generally considered a temperature-sensitive taxon and a warm-water indicator. However, its distribution in the Quaternary section of the Tyrrhenian Basin (Site 132) as well as in the Quaternary of the Ionian Basin (Site 125) is not in agreement with this interpretation. In fact, it is present in intervals which are interpreted as cold on the basis of the faunal assemblages (Site 132) and is dominant in some layers immediately overlying the sapropelitic intervals at Site 125 (Core 3). 
M. B. CITA, M. A. CHIERICI, G. CIAMPO, M. MONCHARMONT ZEI, S. d'ONOFRIO, W. B. F. RYAN, R. SCORZIELLO

TABLE 2

Planktonic Foraminiferal Species in the Quaternary Sediments of Site 125 - Ionian Basin

Globigerina atlantisae Cifelli and Smith

Globigerina bulloides d'Orbigny

Globigerina bulbosa Finlay

Globigerina digitata Brady

Globigerina eggeri Rhumbler

Globigerina falconensis Blow

Globigerina incompta Cifelli

Globigerina pachyderma (Ehrenberg)

Globigerina praedigitata Parker

Globigerina quinqueloba Natland

Globigerina rubescens Hofker

Globigerinita glutinata Egger

Globigerinita uvula (Ehrenberg)

Globigerinoides adriaticus Fornasini

Globigerinoides conglobatus (Brady)

Globigerinoides elongatus (d'Orbigny)

Globigerinoides cf. fistulosus (Schubert)

Globigerinoides gomitulus (Seguenza)

Globigerinoides helicinus (d'Orbigny)

Globigerinoides pyramidalis (d'Orbigny)

Globigerinoides quadrilobatus (d'Orbigny)

Globigerinoides ruber (d'Orbigny)

Globigerinoides sacculifer (Brady)

Globigerinoides tenellus Parker

Globigerinoides trilobus (Reuss)

Globorotalia acostaensis Blow

Globorotalia crassaformis (Galloway and Wissler)

Globorotalia crassaformis viola Blow

Globorotalia inflata (d'Orbigny)

Globorotalia oscitans Todd

Globorotalia scitula (Brady)

Globorotalia tosaensis Takayanagi and Saito

Globorotalia truncatulinoides (d'Orbigny)

Hastigerina pelagica (d'Orbigny)

Hastigerina siphonifera (d'Orbigny)

Orbulina bilobata (d'Orbigny)

Orbulina universa d'Orbigny

Sphaeroidinella dehiscens Parker and Jones

Periods of maximum cooling and the termination of stagnant conditions are marked by efficient renewal of the bottom water by descending blooms of cold dense surface water. This suggests that the ecologic factor controlling the distribution of $G$. conglobatus may be related to phenomena accompanying a strong vertical circulation such as high replenishment of nutrients.

Globigerinoides conglobatus is considered a species living at the surface (see Ruddiman, Tolderlund and Bé, 1970). However, its high resistance to solution (op. cit., p. 151) appears to contradict the above statement, since a positive correlation has been proposed between depth habitat and resistance to solution (Berger, 1970). Moreover, it is hardly believable that the heavily calcified, thick walls of Globigerinoides conglobatus (Plate 6, Figure 6; Plate 7, Figure 2) belong to a species living at the surface. The authors believe that the structure and morphology of the test of $G$. conglobatus suggest a subsurface habitat. Consequently, the taxon is not likely to be sensitive to changes in the superficial temperature of the upper photic zone and this lack of sensitivity may explain why changes in abundance of $G$. conglobatus are not related to the (inferred) paleoclimatic curve.

Globigerinoides elongatus (d'Orbigny), Globigerinoides helicinus (d'Orbigny), and Globigerinoides ruber
(d'Orbigny) are a group of forms which are considered here as discrete taxa. They have in common the position of the primary aperture, which is opposite the intercameral suture separating the penultimate and antepenultimate chambers.

Globigerinoides elongatus is characterized by the very elongated chambers of the last whorl, especially the last-formed one.

Globigerinoides helicinus (Plate 9, Figures 2, 4, and 6) is characterized by the presence of a supplementary chamber, with a supplementary aperture(s). It is always sparse, and probably does not deserve a species rank.

Globigerinoides ruber, as plotted in the graphs, includes the typical form, tapering, with well-separated chambers (Plate 8, Figures 1-6); the more rounded form, with compressed chambers, also recorded as $G$. gomitulus (Seguenza) (Plate 6, Figures 3 and 5); and the streptospiral form, with the axial diameter equal to or longer than the equatorial diameter (G. ruber pyramidalis van der Broeck). In Tyrrhenian Site 132, pink tests of $G$. ruber have never been recorded; not even from the topmost core. This is unlike the findings at other Mediterranean locations (Emiliani, 1971).

Globigerinoides cf. fistulosus (Brady) is present only in the warmest intervals of the Lower Pleistocene. The taxon is characterized by radially elongated proliferations of the last-formed chamber and is strictly related to G. sacculifer. Globigerinoides fistulosus has a very limited stratigraphic range in the Upper Pliocene. It differs from $G$. cf. fistulosus, which ranges into the Quaternary, in the occurrence of proliferations in other chambers. $G$. cf. fistulosus, as represented in the deep-sea Quaternary sediments of the Mediterranean, corresponds to Globigerinoides $\mathrm{cf}$. fistulosus sensu Bolli (1970).

Globigerinoides quadrilobatus (d'Orbigny) (Plate 5, Figures 4-6) is here considered as a discrete taxon, following Banner and Blow (1965). Reference is made to Cita, Premoli Silva and Rossi (1965) for a discussion on the distinctive characteristics of $G$. trilobus. The illustrations (Plate 9, Figures 3 and 5; Plate 5, Figures 5 and 6) clearly show how the differences not only concern the gross morphology (such as the number of the chambers, growth pattern, supplementary apertures) but also the wall surface and structure.

Globorotalia inflata (d'Orbigny) is one of the best represented species in the Quaternary section of Site 132. It is present in varying proportions in most of the samples investigated and is absent in only the coldest intervals.

Two forms may be recognized. One has $3-1 / 2$ to 4 chambers in the last whorl, slightly depressed intercameral sutures, and a finely pitted and distinctly perforated wall (Plate 10, Figures 1-6). The second form is considered a variant of the above described species. It is characterized by a more compact test, an almost rounded equatorial periphery, 3 to $3-1 / 2$ embracing chambers in the last whorl, a long and narrow interio-marginal, umbilical-extraumbilical aperture, and an extremely smooth test surface with very small and widely spaced pores (Plate 11, Figures 1-5). In our evaluation of the specific abundances, Globorotalia oscitans Todd (which is always very rare, if present at all) has been considered together with $G$. inflata, to which it is strictly related. 


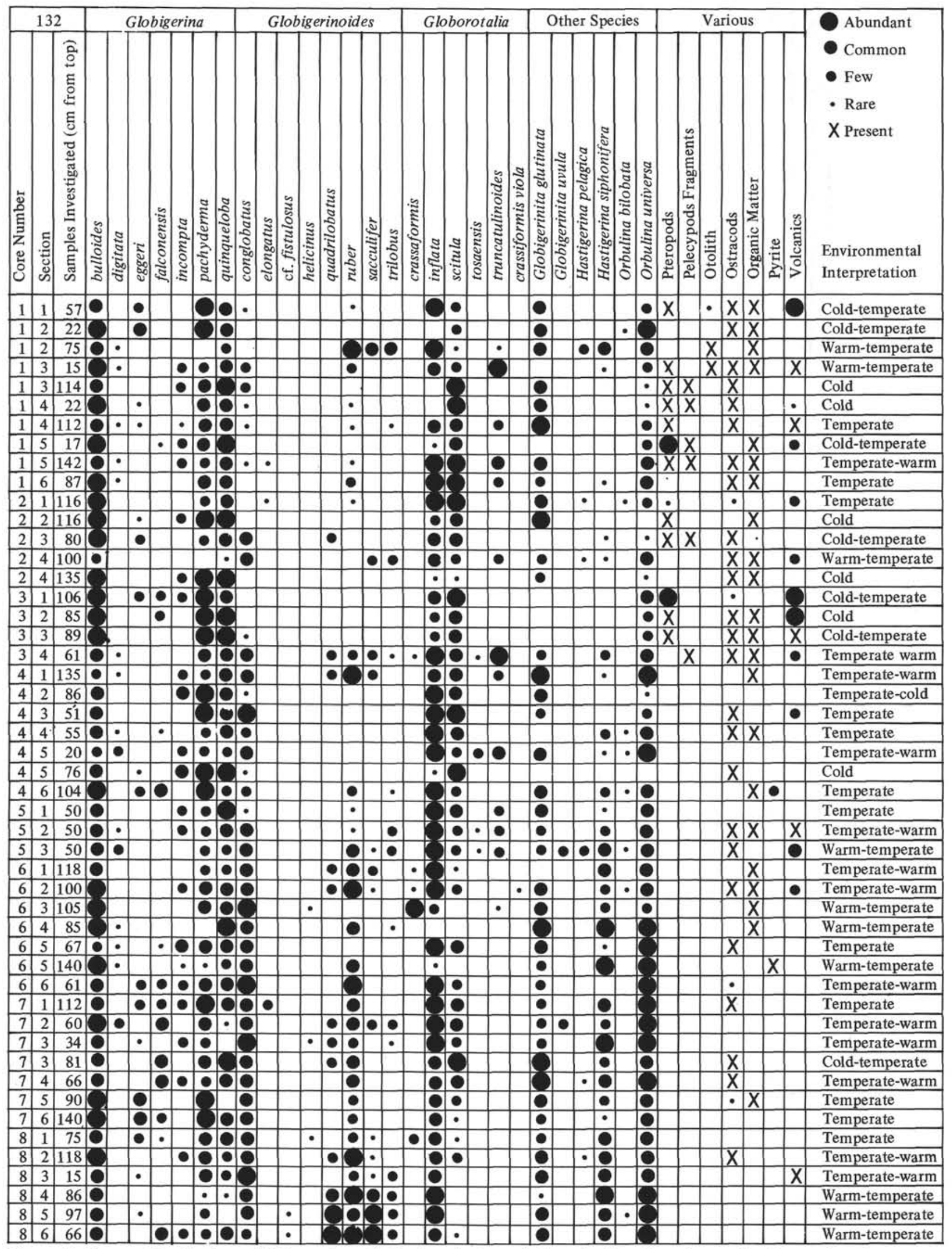

Figure 7. Range distribution of 27 species of planktonic foraminifera in 49 selected samples from the Quaternary cores (1-8) of Site 132, Tyrrhenian Basin. 
M. B. CITA, M. A. CHIERICI, G. CIAMPO, M. MONCHARMONT ZEI,

S. d'ONOFRIO, W. B. F. RYAN, R. SCORZIELLO

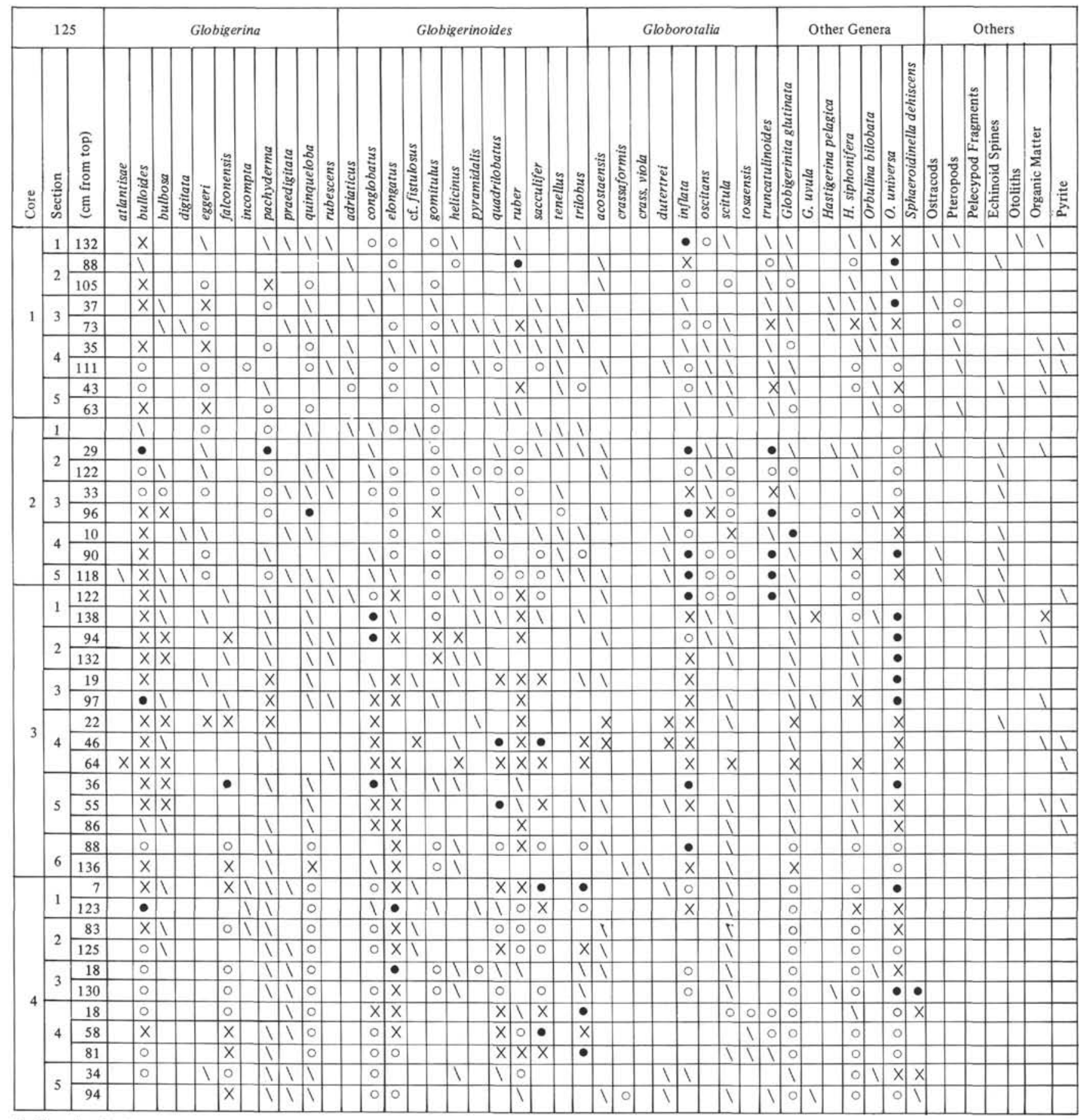

- Very abundant

Abundant

$X$ Frequent

$\backslash$ Rare

Figure 8. Range distribution of 39 species of planktonic foraminifera and other fossil remains in 42 selected samples from the Quaternary cores (1-4) of Site 125, Ionian Basin. 
Globorotalia crassaformis (Galloway and Wissler) (Plate 12, Figures 1-5) and Globorotalia crassaformis viola Blow are present with typical specimens in well-defined levels of Cores 8 and 6.

Globorotalia crassaformis is considered by some authors as a typical Pliocene marker in the Mediterranean region (see Cati et al., 1968). However, it is recorded at Site 132, as well as in other Mediterranean DSDP cores, in Quaternary strata. Both G. crassaformis and G. crassaformis viola are known from Recent and sub-Recent sediments. For further details on the group of Globorotalia crassaformis, reference is made to Chapter 47 on Pliocene biostratigraphy.

Globorotalia scitula (Brady) in varying abundances is well-represented throughout the Quaternary section investigated. According to this preliminary investigation, it seems that no definite changes in the coiling direction occur; a fact which may have some paleoclimatic significance.

Besides the well-known, typical form (see Plate 13, Figures 1-5), we have observed a variant (?) which is characterized by a peculiar ornamentation of the primitive ontogenetic stages. It consists of a kind of alveolar reticulation, continuous from one chamber to the next one, and overriding the intercameral sutures in the very first whorl (see Plate 15, Figures 1-5). The last whorl looks exactly like the typical form.

Specimens from the northern Atlantic off Portugal and Morocco, identical to the ones from the Tyrrhenian Basin have recently been illustrated by Thiede (1971), (op. cit., Plate 9, Figure 3).

Globorotalia-truncatulinoides (d'Orbigny) occurs with typical specimens conical in shape, distinctly keeled - in the warmer intervals of Cores 6 (pars) to 1 (see Plate 16, Figures 1-6). It is definitely not present in Cores 8 and 7 as well as in the greater part of Core 6 . This means that the lowest part of the Pleistocene is devoid of a taxon which is considered by a number of biostratigraphers as an indexfossil, the first occurrence of which characterizes the beginning of the Quaternary (Blow, 1969; Bolli, 1970, inter alia). The absence of $G$. truncatulinoides in the classical Lower Pleistocene Italian sections has already been noticed (Wezel, 1968, Bayliss, 1969). The former author proposes to distinguish biostratigraphically the Calabrian from the Sicilian on the basis of the occurrence of $G$. truncatulinoides in the latter.

Besides this form, which has a deep, but fairly wide and open umbilicus and an abundantly perforated, relatively thin and smooth surface with discrete knobs (see details illustrated in Figures 3, 4, and 5, Plate 16), we found a conical Globorotalia, with a distinctly thicker wall and without visible pores on the surface wall of any of the chambers but the last one (which in turn is the only one possessing a definitely imperforate peripheral keel). This form has been plotted together with $G$. truncatulinoides in the graphs, but can be differentiated morphologically and is illustrated in Plate 17, Figures 2 and 5.

We believe that this taxon may correspond to Globorotalia truncatulinoides pachyteca Blow, 1969. According to Blow (1969), this taxon ranges from the lower part of Zone N.22 to Zone N.23 and to the present time. Bolli (1970) does not distinguish this form in the
Caribbean DSDP drill sites, while Olsson and Goll (1971) recognize it in the eastern Pacific. The range of $G$. truncatulinoides pachytheca in DSDP Site 36 is very limited and characteristic of the lower-middle part of Zone N.22 (latest part of the preglacial Pleistocene) where it occurs along with Globorotalia tosaensis. G. truncatulinoides pachytheca, as recorded in the Tyrrhenian Site 132, is present also in the glacial Pleistocene.

Globorotalia tosaensis Takayanagi and Saito has been recorded in a limited number of samples in Cores 3, 4, 6, and 7 (Plate 17, Figures 3 and 4) often co-existing with $G$. truncatulinoides pachyteca. According to our observations, it may be distinguished from the latter on the basis of the following features:

1) Smaller size $(0.3-0.4 \mathrm{~mm}$ in diameter instead of 0.45-0.55).

2) Absence of a definite, imperforated keel, even in the last-formed chamber (the periphery is narrowly rounded throughout).

3) The umbilicus is narrower and the conical shape is slightly more depressed.

Our specimens compare well with the original figures given by Takayanagi and Saito, and with $G$. tosaensis as recorded in deep-sea sediments of the latest Pliocene (see for instance in the Late Pliocene of DSDP Site 12, Cape Verde, North Atlantic). Also, the wall structure, with its heavy calcification and extremely small pores, is in agreement with the true $G$. tosaensis. For further discussion on the wall structure of both $G$. tosaensis and $G$. truncatulinoides pachyteca see Blow (1969, p. 394). They are strongly different from the $G$. tosaensis shown in Blow's (op. cit.) Plate 40, Figures 4-7, which has a broadly rounded periphery.

Bolli (1970) considers tosaensis as -a subspecies of truncatulinoides and distinguishes two forms: (a) Globorotalia truncatulinoides tosaensis with a thin wall, fairly wide umbilicus and chambers slightly inflated ventrally and (b) G. truncatulinoides cf. tosaensis with a more distinctly conical shape and a very thick wall, with small pores. According to Bolli, their range is different and does not overlap. In fact, $G$. truncatulinoides cf. tosaensis is mutually exclusive with $G$. truncatulinoides. $G$. truncatulinoides tosaensis of Billi has four chambers visible in the last whorl while the existence of five chambers is generally considered as a distinctive characteristic (see for instance Parker 1967, p. 181).

Our finding $G$. tosaensis fairly high in the stratigraphic succession is rather puzzling. ${ }^{4}$ The range of $G$. tosaensis in the Quaternary is questionable, according to the literature available. Olsson and Goll (1970) find $G$. tosaensis as high as the beginning of the glacial Pleistocene. Berggren (1968) indicates a very short overlap of $G$. truncatulinoides and $G$. tosaensis, limited to the lowermost part of the Pleistocene. Blow (1969) indicates an overlap of the two taxa in about $2 / 3$ of Zone N.22. Hays et al., (1969) indicate a wider overlap. According to their findings in the equatorial

\footnotetext{
${ }^{4}$ The lowermost definite period of cooling correlatable with a glacial stage has been found in Core $4-5$, so that there is an overlap between the range of $G$. tosaensis and the glacial Quaternary.
} 
Pacific, G. tosaensis should range as high as the Jaramillo event of the Matuyama reversed epoch, which means up to 0.9 my ago. However, he does not use the extinction horizon of $G$. tosaensis as a datum plane and we suspect that the extinction of this tax on is not strictly isochronous around the world, but that it is ecologically controlled. Further investigations are needed to fully clarify this point.

\section{Discussions of the Site 125 Taxa}

The criteria used for distinguishing the different taxa in the cores from Site 125 are essentially the same as for Site 132. Minor differences, together with the complementary observations concerning taxa which have not been recorded in the Tyrrhenian Basin, will be discussed here.

Globigerina bulloides d'Orbigny is among the most abundant components of the faunas and is present in all of the 160 samples investigated. It shows a certain degree of variability concerning both the dimensions of the test and the aperture (shape and position). Globigerina falconensis Blow and $G$. bulbosa Finlay, which also possess a similar test (with a low trochospire and four chambers in the last whorl), are distinguished from one another and from $G$. bulloides on the basis of the growth pattern (more rapid in $G$. bulbosa, slower in $G$. falconensis) and of the apertural characters (distinct apertural lip in G. falconensis, small, slit-like aperture without lip in $G$. bulbosa).

Globigerina eggeri Rhumbler, unlike at Site 132, is one of the most common taxa at some intervals, especially in the sapropelitic muds present in Core 1 and in the layers immediately overlying the sapropels.

Globigerina eggeri is interpreted here in the same way as in Cita and Chierici (1962, page 320). This reference should also be used for the discussion of this species versus $G$. dutertrei (d'Orbigny). The taxon is fairly high spired, with at least five chambers in the last whorl. It is subspherical in shape, and the aperture is definitely umbilical. It is commonly lumped together with $G$. dutertrei (see for instance Bolli (1970). G. dutertrei is considered to be a discrete taxon and is separated from $G$. eggeri because of its umbilical-extraumbilical aperture, more elongated equatorial outline, different growth pattern, and less elevated spire.

Globigerinoides conglobatus (Brady) is present in quite an unusual abundance in Core 3, which is associated with the sapropelitic intervals. Well-developed specimens, subspherical in shape as Orbulina universa and as large as this taxon (size up to $1 \mathrm{~mm}$ ), are present in abundance. In Core 1, the taxon is usually represented by smaller specimens which may be confused with $G$. ruber (juvenile forms). A distinction is always possible by taking into account the wall structure.

The group of Globigerinoides ruber (d'Orbigny) is more subdivided here than in the investigations of the Site 132 taxa. Besides, G. ruber, G. helicinus and G. elongatus, we also plotted as discrete taxa $G$. gomitulus and $G$. pyramidalis. The former is characterized by its subspherical shape, compressed terminal chamber, low trochospire, and small average size, and the latter by its very high spire, tapering test, and large average size.

Globigerinoides adriaticus has been recorded from the Quaternary cores at Site 125 with fairly rare, but typical specimens, which compare well with the original figures given by Fornasini. It is a very high-spired Globigerinoides with $3-1 / 2$ to 4 chambers in the last whorl and supplementary apertures which are fairly small, and visible on the last two or three chambers. It differs from $G$. ruber s. s., as well as from other taxa belonging to the G. ruber group, essentially by the position of the primary aperture, which is opposite the antepenultimate chamber.

Globorotalia inflata (d'Orbigny) is the most commonly recorded species belonging to the genus Globorotalia. Two different forms (variants?) are present in the samples investigated from Site 125, as well as in those from Site 132. The more involuted form, with only 3 to $3-1 / 2$ embracing chambers in the last whorl and a very elongated umbilical-extraumbilical aperture, does not appear to be ecologically differentiated from the usual form, with which it always co-occurs.

Globorotalia oscitans Todd, which has been plotted along with $G$. inflata is present here with the same characteristics recorded at Site 132 and ranges up to the glacial Pleistocene (Core 1).

The coiling ratio of Globorotalia truncatulinoides has been studied in detail by one of us (S.d'O.) in Cores 1 and 2. Generally speaking, left-coiling specimens are more abundant (see Figure 6). Definite changes in the proportions of left-coiling versus right-coiling specimens are observed in Samples 1-2 $(65-67 \mathrm{~cm}), 1-2(130-132 \mathrm{~cm})$ and $1-3(88-90 \mathrm{~cm})$. They do not appear to be related to climatic changes (all the intervals referred to are considered as temperate-warm), but other intervals with the same climatic evaluation do not show behavior similar to that of $G$. truncatulinoides) nor to changes in salinity (viz. sapropelitic cycles).

\section{PALOENVIRONMENTAL EVALUATION OF THE FORAMINIFERAL FAUNAS}

The inferred climatic curves shown in Figures 4 and 6 are based on the occurrence and relative abundance of a number of species generally used as climatic indicators. We suspect that ecological factors, other than surface temperature, may influence the distribution and diversity of life at the surface of the sea, in the subsurface, and at the bottom. We and others (Parker, 1958; Olausson, 1961, 1965) have noted faunal assemblages in the eastern Mediterranean that show a striking association with levels of sapropel mud, suggesting that the periods of bottom-water stagnation also exerted an environmental influence on the pelagic faunas.

For the purpose of further evaluating the climatic curves, a brief description is included of some more or less typical assemblages of planktonic foraminifera which we consider representative of (a) warm-water conditions, (b) temperate conditions, (c) cold-water conditions, and (d) the intervals of sapropelitic sedimentation.

\section{Warm-Water Assemblages}

In the first class, warm-water conditions, we were able to recognize a warm-temperate assemblage of the late Pleistocene as distinguishable from a warm-temperate assemblage of the early Pleistocene. From the Tyrrhenian Basin, a typical assemblage $(132-2-4,100 \mathrm{~cm})$ of the late Pleistocene is very rich in dominantly large sized representatives of the 
genus Globigerinoides, with species like $G$. conglobatus, $G$. quadrilobatus, $G$. ruber, $G$. sacculifer. Globorotalia inflata is abundant and well-developed as is Orbulina universa, which often exceeds $1 \mathrm{~mm}$ in diameter. Other Globorotalia present are $G$. truncatulinoides and $G$. scitula. The genus Globigerina is represented by some 4 or 5 species, including $G$. eggeri, $G$. digitata and $G$. praedigitata. $G$. pachyderma is rare and always right-coiling. The genus Hastigerina is fairly well represented; both $H$. siphonifera and $H$. pelagica are present. The fauna is well diversified and shows evidence of eutrophic conditions.

In the same basin, a typical warm-temperate assemblage $(132-6-3,105 \mathrm{~cm})$ of the early Pleistocene would be similar to the above, but would be lacking in Globorotalia truncatulinoides. $G$. crassaformis is abundant at some intervals and Hastigerina pelagica may be present as rare specimens. The numerical ratio between representatives of Globigerinoides conglobatus versus $G$. ruber appears to be variable. Globigerina bulloides often occurs as large specimens with wide apertures.

\section{Temperate Assemblages}

The most conspicuous component of the typically temperate faunas is Globorotalia inflata. In a temperate interval $(132-4-2,30 \mathrm{~cm})$ both Globigerina bulloides and $G$. falconensis are well represented. The assemblages are less diverse than in the previously examined cases; usually absent are Globigerina digitata-praedigitata, Hastigerina pelagica, and Globigerinoides sacculifer. Globorotalia truncatulinoides is either rare or absent, while Hastigerina siphonifera is usually present, but never as common as in the warmer intervals. The size of the tests, apart from the small species such as Globigerina quinqueloba, Globorotalia scitula, and Globigerinita glutinata, is fairly uniform.

\section{Cold-Water Assemblages}

Foraminiferal assemblages of the cold-water intervals $(132-3-2,142 \mathrm{~cm})$ are dominated by Globigerina pachyderma with right- and left-coiling specimens, the latter usually being smaller than the former. Globigerinoides and Globorotalia with the exception of Globorotalia scitula, which is usually abundant, are little represented, if at all. Orbulina is rare, and is absent in the coldest intervals, along with Globorotalia inflata. The genus Globigerina is dominant, in terms of both number of species and number of specimens. Globigerina bulloides is always quite abundant. Compared with the warmest intervals, the faunal diversity is very limited. Usually, only half as many species are recorded in the cold- as in the warm-water intervals.

\section{Sapropel Assemblages}

Assemblages differing in ways from those here considered as "normal" are present in the sapropel layers at Site 125 in the Ionian Basin as well as in the immediately overlying and/or underlying layers. It is beyond the scope of this preliminary discussion to report a detailed investigation on the foraminiferal assemblages of the sapropels. A few preliminary remarks follow:

1) The sapropel intervals of Core 1 of Site 125 are thinner than those of Core 3 , and the associated planktonic assemblages are apparently not as strongly modified as those observed in Core 3. In the thin sapropel layers of Sample 1-3, 37-39 cm, Globigerina bulloides and G. eggeri are among the best represented species, while Globigerinoides spp. and Globorotalia truncatulinoides are relatively rare, suggesting a temperate (?) climate.

The sapropel layer investigated in Sample 1.4, 101-103 $\mathrm{cm}$, also contains $G$. bulloides and $G$. eggeri in abundance. The assemblage is almost oligotypical, and indicates more important ecological controls related to restricted circulation than in the previously discussed interval, this is in agreement with the greater thickness of this sapropelitic layer, as compared to the one contained in Core 1, Section 3 .

The assemblage dominated by $G$. bulloides and $G$. eggeri is found in the sapropel layer investigated from Sample 1-5, $63-65 \mathrm{~cm}$ as well. This layer also contains a few Globigerinoides spp. and $G$. truncatulinoides. Globigerinoides gomitulus is the best represented species of Globigerinoides in all the samples of Core 1.

2) The sapropelitic intervals of Core 3 contain faunal assemblages different from those of Core 1. Globigerina eggeri is not an important constituent, being either absent or poorly represented. Globorotalia truncatulinoides is absent in the over 40 samples investigated from this core. The dominant species are Orbulina universa, Globigerinoides conglobatus and, in some intervals, Hastigerina siphonifera, all of these are considered warm-water indicators. The first two species are often very well developed, approaching $1 \mathrm{~mm}$ in size.

3) A difference in the composition of the planktonic foraminiferal assemblages occurring respectively below and above the sapropelitic layers was noted. Globigerinoides conglobatus appears to be more abundant during periods of stagnation and immediately after, rather than before the onset of stagnation.

4) The lack of Globorotalia truncatulinoides and the general scantiness of species of Globorotalia living in subsurface waters support the suggestion that they are more sensitive to changes in the thermocline than to changes in surface temperature.

5) The above observations, as a whole, indicate that periods of stagnation did not affect only the bottom-living organisms, but that these cyclically repeated events resulted in changes in salinity and in other physio-chemical characteristics and thus also strongly controlled planktonic organisms living at the surface and in the subsurface waters.

\section{Volcanic Activity and Its Influence on the Fossil Assemblages}

Sixty-seven out of the two-hundred and twenty samples investigated from Site 132 in the Tyrrhenian Basin contain some volcanic material (pumice and glass shards). Although there are several discrete tephra layers at Site 125 in the Ionian Basin, some of which may even be correlatable to those in the Tyrrhenian Basin (see Figure 9), the volume of volcanic material is significantly less at this site than at Site 132. Generally speaking, the content of volcanic material diminishes toward the bottom of the Quaternary succession. Volcanic material is practically absent in the lowermost part.

In some intervals in which there is a significant amount of volcanic material, the foraminiferal faunas are scanty and 
A.
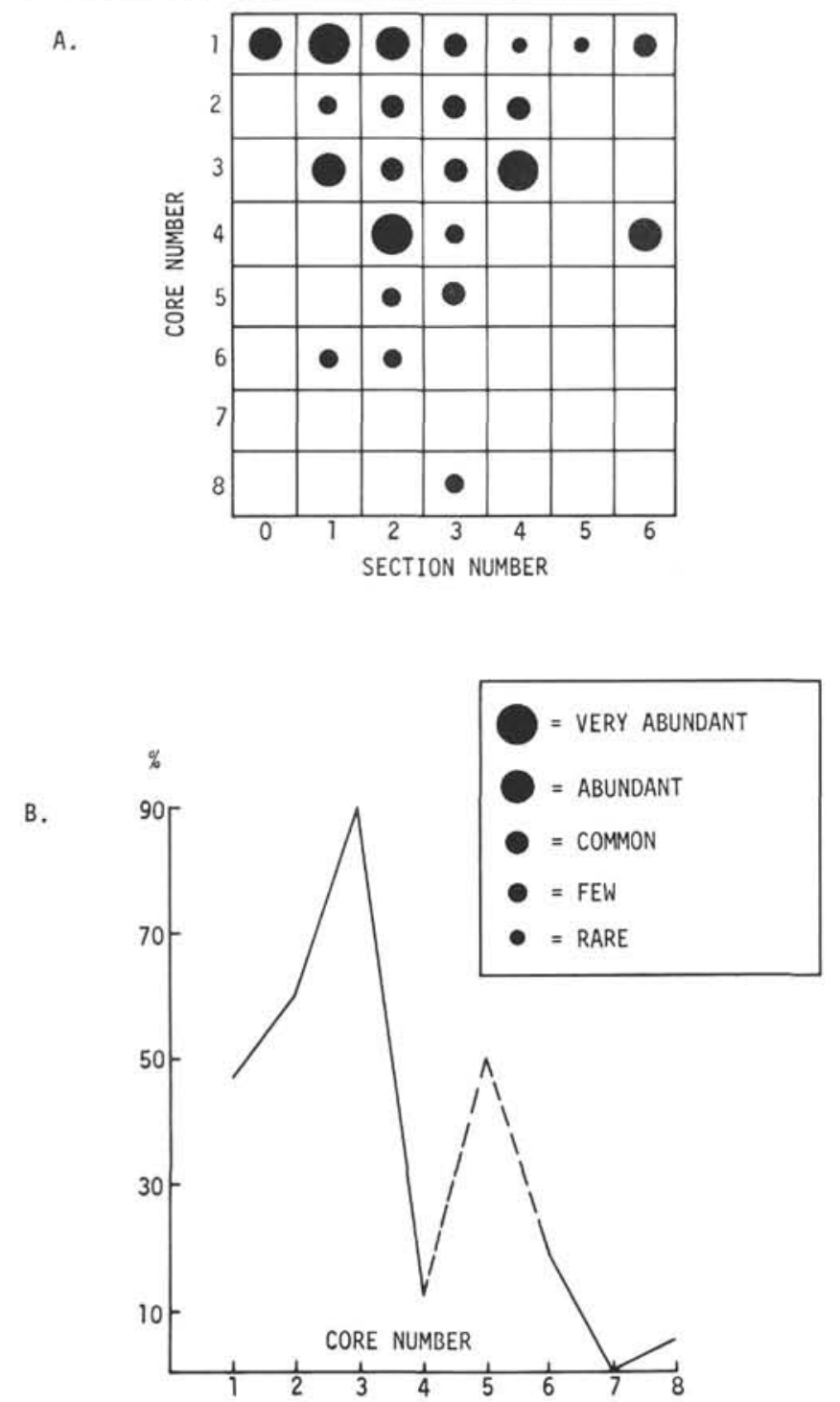

Figure 9. (A) Relative abundance of volcanic material in the sand-sized fraction of the samples investigated from Cores 1 to 8, Site 132. (B) Percentages of samples containing volcanic material in Cores 1 to 8 , Site 132.

small sized. This may be the result of the environment suddenly becoming unfavorable in the wake of catastrophic eruptions. According to our evidence, the species which react the most to the ecologic changes introduced by ash falls belong to the genus Globigerina ( $G$. bulloides, $G$. pachyderma, G. quinqueloba). Pteropods are particularly abundant in levels rich in volcanic material, as evidenced in piston cores by Ryan and Heezen (1965) and by Ninkovich and Heezen (1965).

\section{THE BENTHIC FAUNA AND OTHER FOSSIL REMAINS}

In all the samples investigated from the Quaternary successions cored at both Sites 132 and 125, the benthic assemblages are extremely rare, usually representing much less than one per cent of the biogenic fraction. This scantiness of the bottom-living fauna, however, cannot be controlled entirely by unfavorable life conditions near the sediment-water interface due to oxygen-depleted bottom water, because the fauna is also scarce in the well-oxidized tan- and buff-colored lithologies. Pyrite concretions, indicating reducing conditions at the bottom, have been found in only 6 samples out of the 220 investigated at Site 132. The authors believe that the sparceness of the benthic faunas throughout the Quaternary is essentially an indication of a bathyal depositional environment in the Tyrrhenian and Ionian basins through Plio-Pleistocene time.

The sapropel layers are praatically devoid of benthic foraminifera as well as of the fossils of any organisms which live on the bottom such as ostracods, echinoids, pelecypods. However, single shells of imperforate foraminifera (Miliolids) were found in some sapropelitic intervals, as for instance in Core 1, Section $3(138-140 \mathrm{~cm})$. In agreement with what has been observed for Site 132, we believe their occurrence is related to the possibility of buoying after having been removed from their natural habitat.

\section{Benthic Foraminifera}

The sand-sized sediment fraction obtained from about $5 \mathrm{cc}$ of wet sediment usually contains only three to ten individual specimens of benthic foraminifera. Individual species are seldom represented by more than one specimen. However, Articulina tubulosa is sometimes present as four to five specimens. This species, according to Parker (1958, p. 255), is considered a true deep-sea form.

The present day water depth at Site 132 is 2845 meters; 2782 meters for Site 125. The information we have from the literature concerning the distribution of benthic foraminifera in the Tyrrhenian Basin is unfortunately very limited (see Moncharmont Zei 1964, Iaccarino, 1967), and mostly concerns locations in water depth of less than 1000 meters.

The only bathymetric zonations based on benthic foraminifera for the Mediterranean in general are by Parker (1958), Chierici, Busi and Cita (1962), and Blanc-Vernet (1969). No indications of littoral environment are given by the benthic assemblages of either drill site. Only Nonionella turgida (present as a single specimen in sample 125-1-3, $51-53 \mathrm{~cm}$ ) is usually recorded at lesser depths (Zone C of d'Onofrio, 1970, in the Po Delta).

It is worthwhile mentioning that the occurrence of species belonging to the genus Bulimina appear to be restricted to particular intervals and are lacking in the greater part of the samples investigated. They occur in a relatively greater amount in Samples 125-1-3, 26-28 cm; $125-1-4,35-37 \mathrm{~cm} ; 125-1-4,65-67 \mathrm{~cm} ; 125-2-2,16-18 \mathrm{~cm}$; $125-2-3,13-15 \mathrm{~cm}$; and $125-2-4,146-148 \mathrm{~cm}$. The climatic indications given by planktonic foraminifera which are associated with the same intervals vary from temperate to warm-temperate; however, we doubt that a change in surface water temperature would have a significant effect on the distribution of bottom-living forms at depths over 2000 meters.

The benthic assemblages of Sites 132 and 125 are listed in Tables 3 and 4 respectively. 
TABLE 3

Benthic Foraminiferal Species in the Quaternary Sediments of Site 132 - Tyrrhenian Basin. ${ }^{a}$

Articulina tubulosa (Seguenza)

Bigenerina nodosaria d'Orbigny

Bolovina spp.

Bulimina aculeata d'Orbigny

Bulimina marginata d'Orbigny

Bulimina ovata d'Orbigny

Cassidulina crassa d'Orbigny

Cassidulina laevigata d'Orbigny

Comuspira involvens (Reuss)

Dorothia sp.

Eggerella sp.

Eponides umbonatus (Reuss)

Gyroidina spp.

Lenticulina spp.

Pleurostomella alternans Schwager

Pullenia bulloides (d'Orbigny)

Pyrgo depressa (d'Orbigny)

Pyrgoella sphaera (d’Orbigny)

aList arranged alphabetically. Identification by M. Z.

TABLE 4

Benthic Foraminiferal Species in the Quaternary Sediments of Site 125 - Ionian Basin ${ }^{2}$

\author{
Articulina tubulosa (Seguenza) \\ Bulimina aculeata d'Orbigny \\ Bulimina affinis d'Orbigny \\ Bulimina etnea Seguenza \\ Bulimina gibba Fornasini \\ Bulimina inflata Seguenza \\ Bulimina marginata d'Orbigny \\ Bulimina pupoides d'Orbigny \\ Cassidulina neocarinata Thalmann \\ Chilostomella oolina Schwager \\ Cibicides lobatulus (Walker and Jacob) \\ Cibicides pachyderma (Rzehak) \\ Cibicides robertsonianus (Brady) \\ Cibicides wuellerstorfi (Schwager) \\ Dentalina leguminiformis (Batsch) \\ Eponides umbonatus (Reuss) \\ Fissurina marginata (Montagu) \\ Fissurina orbignyiana (Seguenza) \\ Fissurina staphyllearia (Schwager) \\ Fursenkoina complanata (Egger) \\ Fursenkoina tenuis (Seguenza) \\ Gyroidina laevigata d'Orbigny \\ Gyroidina cf. neosoldanii Brotzen \\ Karreriella bradyi (Cushman) \\ Lagena apiopleura Loeblich and Tappan \\ Nonionella turgida (Williamson) \\ Pullenia bulloides (d'Orbigny) \\ Pullenia quinqueloba (Reuss) \\ Pyrgo bulloides (d'Orbigny) \\ Pyrgo depressa (d'Orbigny) \\ Pyrgo serrata (Bailey) \\ Quinqueloculina padana Perconig \\ Robertina arctica d'Orbigny \\ Triloculina tricarinata d'Orbigny
}

a List arranged alphabetically. Identification by S. d'O.

\section{Other Fossil Remains}

Pteropods, echinoid spines, thin juvenile shells of both pelecypods and gastropods are recorded in many of the samples investigated. No debris of adult, fully developed shells, however, were noted; this further supports the interpretation of a very deep depositional environment for the Quaternary sediments in the two basins.

Pteropods occur in strongly variable amounts in Core 1 of Site 125; they are totally lacking in the sapropelitic layers. However, they are present in abundance in the layers immediately overlying and/or underlying the sapropels. Below Core 1 they are extremely rare. Similarly, at Site 132 pteropods have been noted only in the upper level (Cores 1 to 3 ).

Echinoids are represented by thin calcitic spines, often in fragments, and small calcitic plates. The spines belong mostly to irregular forms. Other fossil debris includes thin, branched, and slender calcitic spines, interpreted as skeletal remains of juvenile echinoids. The echinoid remains are present only in normal pelagic sediments, and are lacking in the sapropelitic layers.

Ostracods are extremely rare at Site 125 , occurring as single valves at scattered intervals. They are less represented here than in the Tyrrhenian Basin. They never occur in the sapropelitic layers.

Fragments of pelecypods are also extremely rare in the cores investigated, and always belong to juvenile forms with a pelagic habitat. They were very seldom recorded.

Brownish to yellow fragments of organic matter (fish scales, vertebrae, and other unidentifiable remains) are present in a number of samples in extremely small amounts. They are present in abundance in the sapropelitic layers. Other fish remains include teeth (phosphates) and otoliths (carbonates). They occur with (relatively) greater abundances in the sapropelitic layers.

A chemical analysis of the sapropelitic interval at 138 to $140 \mathrm{~cm}$ of Core 3, Section 1, has been made at the Laborotorio di Geologia Marina of the Consiglio Nazionale delle Ricerche in Bologna, with a chromatograph HewlettPackard 185 . The following results have been obtained:

$\begin{array}{lr}\mathrm{C} & 21.0 \% \\ \mathrm{H} & 2.9 \% \\ \mathrm{~N} & 1.2 \% \\ \mathrm{O} & 27.1 \% \\ & 47.6 \% \\ & 99.9 \%\end{array}$

\section{Ostracods and Their Bathymetric Implications (G.C.)}

Preliminary investigations have been made of the ostracods in a limited number of the samples from Site 132 (Cores 1-8). The investigations were oriented towards an evaluation of the paleo-depth of the depositional area. Our findings are tabulated in Figure 10.

The ostracod assemblages are generally very similar to those known from the deepest parts of the Mediterranean, a sea in which a true abyssal (psychrospheric) ostracod fauna is lacking (Benson, 1969). According to Puri, Bonaduce and Gervasio (1969) the assemblages recorded in the deepest basins of the Mediterranean differ from typically bathyal ones mainly because of smaller faunal diversity.

The paleo-depth at Site 132, based on the samples investigated, is estimated to be between 2000 and 3500 meters, more likely between 2500 and 3000 meters. The lower limit is suggested by the monotony of the assemblages. Genera which are recorded at depths of 2000 
M. B. CITA, M. A. CHIERICI, G. CIAMPO, M. MONCHARMONT ZEI, S. d'ONOFRIO, W. B. F. RYAN, R. SCORZIELLO

\begin{tabular}{|c|c|c|c|c|c|c|c|c|c|c|c|c|}
\hline \multirow[b]{2}{*}{$\begin{array}{l}\text { LEGEND: } \\
\qquad \begin{array}{ll}* & \text { Present } \\
\text { A } & \text { Abundant } \\
\text { C } & \text { Common } \\
\text { F } & \text { Frequent } \\
/ & \text { Rare }\end{array}\end{array}$} & \multicolumn{12}{|c|}{ Site 132 Samples (cm from top) } \\
\hline & $\begin{array}{l}\text { ह } \\
\infty \\
\Xi \\
\tilde{n} \\
\infty\end{array}$ & $\begin{array}{l}\text { ह } \\
8 \\
\Omega \\
\hat{2} \\
\end{array}$ & $\begin{array}{l}E \\
\tilde{b} \\
\vdots \\
0 \\
0\end{array}$ & 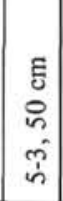 & 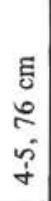 & $\begin{array}{l}\text { ह } \\
\bar{n} \\
\dot{f} \\
\dot{+}\end{array}$ & $\begin{array}{l}\text { ह } \\
\bar{\sigma} \\
\dot{+} \\
\tilde{m}\end{array}$ & $\begin{array}{l}\text { हี } \\
\text { مे } \\
\text { mे } \\
\text { n் }\end{array}$ & $\begin{array}{l}E \\
\tilde{L} \\
\infty \\
\dot{J} \\
\text { d }\end{array}$ & 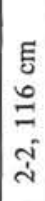 & $\begin{array}{l}E \\
\tilde{n} \\
\stackrel{\sim}{\check{I}}\end{array}$ & 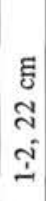 \\
\hline Paleoclimatic Interpretations & TW & $\mathrm{T}$ & TW & WT & $\mathrm{C}$ & $\mathrm{T}$ & TW & CT & TW & $\mathrm{C}$ & WT & $\mathrm{T}$ \\
\hline ??Thaumatocypris sp. & & & & & & & & * & & & & \\
\hline Polycope dentata Brady & $*$ & * & & * & & $*$ & * & & $*$ & $*$ & $*$ & \\
\hline Polycope striata Müller & & * & & & $*$ & & $*$ & $*$ & $*$ & $*$ & $*$ & \\
\hline Polycope reticulata Müller & & & & * & & & & & $*$ & & & \\
\hline Polycope sp. & & & & & * & & * & * & & $*$ & * & \\
\hline Cytherella vulgata Rugg. & & * & & & & & & & & & & \\
\hline Bythocypris obtusata Sars & & & & & & & * & * & * & & & * \\
\hline Propontocypris ?pallida (Müller) & & & & & * & & * & & & & * & \\
\hline Argilloecia acuminata Müller & & * & * & * & & & $*$ & * & * & * & * & * \\
\hline Argilloecia sp. & & & * & & * & & & * & & & & \\
\hline Macrocypris minna (Baird) & & & & & & & & $*$ & & & & \\
\hline Buntonia sp.j.f. & & & & & & & & & & * & & \\
\hline Eucythere declivis (Norman) & & & & & & & & * & & * & & \\
\hline Krithe bartonensis (Jones) & & * & * & & * & * & & & & & & \\
\hline ?Eucytherura sp. 1 & * & $*$ & & & & $*$ & & & * & & & * \\
\hline Eucytherura sp. 2 & * & * & & & & & & & & & & \\
\hline Paijen borchella malajensis Kingha & * & * & & & & & & & & & & \\
\hline Cytheropteron alatum Sars & * & * & & & & * & & * & * & * & & $*$ \\
\hline Cytheropteron rotundatum Müller & & & & & & & & & & & & $*$ \\
\hline Pseudocythere caudata Sars & & * & & & & * & & $*$ & & * & & \\
\hline Monoceratina sp. & & * & & & & & * & * & & * & & \\
\hline ?Paracytherois $\mathrm{sp}$ & & * & & & & $*$ & & & * & * & & \\
\hline Xestoleberis ?depressa Sars & & & & & & & & & & * & & \\
\hline Volcanic contribution & 7 & $T$ & 7 & $\mathrm{~F}$ & l & / & $\mathrm{C}$ & A & A & 1 & $\mathrm{C}$ & 1 \\
\hline
\end{tabular}

Figure 10. Distribution of Ostracods in 12 selected samples from Cores 1 to 8, Site 132.

meters or less were not seen in our samples, as for instance, Semicytherura, recorded in the Mediterranean as deep as 2159 meters (Puri et al., 1969), Pterygocythereis, Paradoxostoma, etc. Below 3500 meters, both in the Mediterranean and in the North Atlantic (Tressler, 1941), the ostracod assemblages are far less diversified than the ones in our samples.

The bathymetric evaluation discussed above is mainly based on the present-day distribution of Argilloecia acuminata, Bythocypris obtusata, Pseudocythere caudata, Cytheropteron alatum, and Macrocypris minna.

A relatively higher number of species is recorded in some samples. This may be accounted for by the presence of volcanic material, which probably represents a more preferable substratum for the ostracods than the usual Globigerina ooze. However, some of the samples richest in ostracod species, as for instance 132-2-2, $116 \mathrm{~cm}$ are devoid of volcanic material. The occurrence in this sample of Pseudocythere caudata, Eucythere declivis, Xestoleberis? depressa, and Cytherella vulgata (a single juvenile valve) which very rarely have been recorded below 2500 meters is noted.

The ostracods investigated indicate that the sediments are in place; in fact, the adult carapaces are almost always accompanied by juvenile stades (instars) and no trace of reworked forms was seen.
The occurrence of Paijenborchella malajensis in the samples investigated from Cores 7 and 8 is interesting from a stratigraphic point of view; this species is relatively common in Italy in deep-sea deposits near the PliocenePleistocene boundary, and is living in the present seas along the southwestern border of the Pacific Ocean.

\section{CORRELATIONS BETWEEN THE TYRRHENIAN AND IONIAN BASINS AND OTHER AREAS}

A correlation between the Quaternary sections recovered at Site 125 in the Ionian Basin and Site 132 in the Tyrrhenian Basin is possible on the basis of (a) biostratigraphic events, (b) paleomagnetic events, (c) paleoclimatic events, and (d) time-synchronous lithologies. Although these two sedimentary columns are more than one thousand kilometers apart, they have shared a rather complex depositional history and apparently have recorded it faithfully. The proposed correlations are shown in Figure 11.

The biostratigraphic correlations are based on zonations of the calcareous nannofossils. The nannofossil stratigraphy has been worked out by H. Stradner (see Chapter 41) and D. Bukry (see Chapter 33). These two researchers use slightly different criteria for their zonations, and similar vertical relationships of their zones at several drill sites provide an independent check -on the reliability of their 


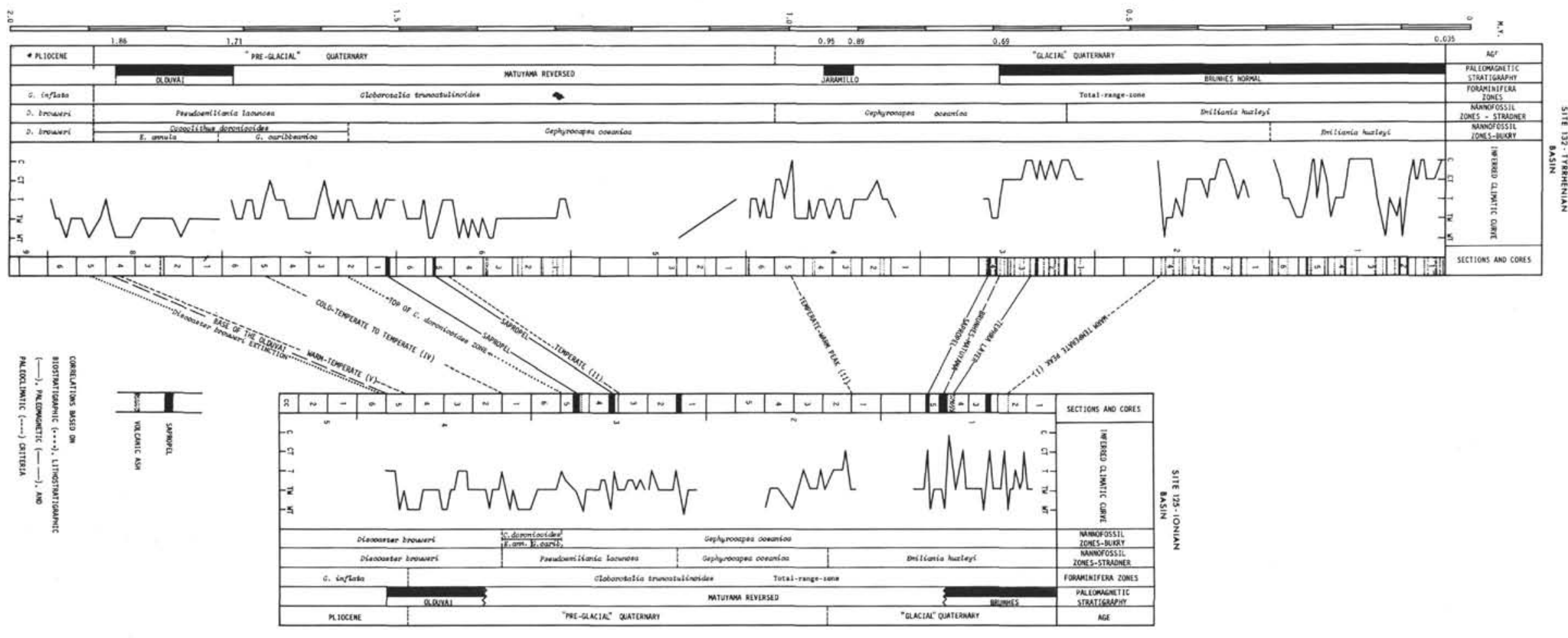

Figure 11. Proposed correlations between Site 132, Tyrrhenian Basin and Site 125, Ionian Basin. Equivalent levels in the two sedimentary columns are matched on the basis of (1) biostratigraphic events, (2) similarities in the behavior of the inferred climatic curves, (3) time-synchronous paleomagnetic horizons (measured and interpolated), and (4) lithostratigraphic horizons such as sapropels and tephra layers (discrete volcanic eruptions deduced from comparative studies of the refractive indices of the glass shards). The nannofossil zonations shown are after Bukry (Chapter 33.1 of this volume) and Stradner (Chapter 33.2). The paleomagnetic time scale is from Foster and Opdyke (1970). The sapropels at Site 132 are generally not as dark-colored nor as rich in organic material as those at Site 125, but nevertheless are clearly deposits of euxinic or near-euxinic conditions (i.e., finely laminated and without a benthic fauna). 
boundaries. Both were able to identify established Quaternary nannofossil zones, further supporting our assumption that the Quaternary is completely represented in the two Mediterranean basins.

In Bukry's scheme, the lowermost Pleistocene can be divided into a lower Emiliania annula Subzone and an upper Gephyrocapsa caribbeanica Subzone of the Coccolithus doronicoides Zone. Although the same zonal markers (Gephyrocapsa oceanica and Emiliania huxleyi) are used by the cited authors for the middle and late Pleistocene, the zonal boundaries are defined in different ways, causing some apparent inconsistency between the nannofossil zones, as shown in Figure 11.

\section{Biostratigraphic Correlations}

A very good correlation exists for the top of the $C$. doronicoides. G. caribbeanica Zone, which lies at the base of Core $3(25 \mathrm{~m})$ at Site 125 and in the top of Section 3, Core $7(57 \mathrm{~m})$ at Site 132.

Correlations at the other zonal boundaries are less satisfactory, and give way to more controlled correlations from the paleomagnetic and paleoclimatic data.

\section{Paleomagnetic Correlations}

The Brunhes-Matuyama boundary is located in Section 4 of Core 3 at Site 132. The boundary itself was not found at Site 125; however, we point out that the lowermost level which could be reliably sampled in Core 1 of Site 125 was at $130 \mathrm{~cm}$ in Section 4, and, like all the samples above, it was normally magnetized. Section 5 of Core 1 and all of Core 2 were too disturbed for measurement. The upper 6 meters of Core 1 of Site 125 must thus correlate above Section 4 of Core 3 of Site 132. The other paleomagnetic boundaries in the Quaternary were either not detected at both sites or were too poorly defined to provide useful criteria for cross-correlation.

\section{Paleoclimatic Correlations}

The inferred climatic curves shown in Figure 11 are cross-correlated at five levels from top to bottom.

1) The sudden change from the greatest (estimated) warm to the greatest (estimated) cold found in the lower part of Core 1, Section 2 of Site 125 and in the lower part of Core 2, Section 4 of Site 132 are interpreted as probably isochronous; the paleoclimatic curves of the interval immediately overlying this sudden change are very similar in both sites. A comparison of the underlying interval is hampered by the interruption of the sedimentary record at Site 132 (Core 2 has only 4 sections instead of 6).

2) The lowest cold interval recovered at Site 125 in the topmost part of Section 2, Core 2 and the lowest cold interval recovered at Site 132 in the middle part of Section 5 , Core 4 are considered isochronous. The inferred climatic curves for the underlying interval are very similar at both sites.

3) The thickest sapropel layer recovered in the Quaternary succession of Site 125 (upper part of Section 4 , Core 3), which is some $25 \mathrm{~cm}$ thick, is considered to be the same as that in the lower part of Section 5, Core 6, Site 132. In the latter, there is an anomalous, oligotypical planktonic assemblage with abundant pyrite crystals thus indicating reducing conditions at the bottom. Both intervals correspond to a short warm interval, with indications of temperate conditions both above and below.

4) Three levels characterized by temperate faunas are recognizable at Site 125 (top of Section 6, Core 3; top of Section 2, Core 4, middle part of Section 3, Core 4) in an interval dominated by warm-temperate assemblages overlying the Pliocene-Pleistocene boundary. Two of these three levels are recognizable at Site 132 (Section 3 of Core 7; Section 5 of Core 7), while the third peak is possibly included in the missing part of Section 1, Core 8. The trend of the inferred climatic curves both above and below is very similar and can be tentatively correlated.

5) An abrupt warming occurs in Section 5 of Core 4 at Site 125, and in Section 4 of Core 8 at Site 132. This change from temperate to warm-temperate is the only one that appears between level 4 and the base of the Quaternary.

\section{Lithologic Correlations}

Certain of the lithologies recovered suggests deposition of time-synchronous strata over large areas. For example, the occurrence of sapropelitic muds in the Quaternary succession of the eastern Mediterranean has been known ever since the recovery of long piston cores during the Swedish Deep-Sea Expedition (1946-1948). Alternating layers of oxidized and reduced deposits suggest cycles in the oxygen content of the bottom water (Olausson, 1961, 1965). Periods of nonventilation have led to oxygen deficiency and, hence, reducing conditions at the sea floor, with resulting deposition of organic muds. According to Olausson the process is glacio-eustatically controlled as follows:

1) During periods of glacially lowered sea level (about 100 meters lower than present) communication between the western and eastern Mediterranean became restricted through the straits of Sicily, resulting in an increase of salinity in the eastern basins, notwithstanding the (eventual) increase in runoff and precipitation. At the same time, the surface water temperature decreased about four degrees centigrade. The resulting increase in the density of the surface water led to a continual renewal of the bottom water mass (e.g. oxidizing environment).

2) During deglaciation, when sea level rose, water density tended to decrease near the surface, as the result of less saline water added from the Atlantic through the western Mediterranean. As this transgression persisted, sea-level eventually reached the elevation of the sill at the Bosporus ( $40 \mathrm{~m}$ ), and low-density water from the Black Sea in turn poured out in large amounts into the Aegean, further lowering the density of surface water of the eastern Mediterranean. Since the rise in sea level was accompanied by a temperature increase, the combination of warm, low-density superficial water led to density stratification and an eventual stagnation of the bottom water.

The above model was first proposed by Olausson (1961) for the younger postglacial and interglacial sapropelitic layers investigated in piston cores. This model was also applied by Ryan (in press), who demonstrated a rather precise relationship between timings of the stagnations and climatic fluctuations. 
Since the organic muds result from brief periods of basin-wide stagnation, they are obviously time-synchronous depositional units. One of our new findings is that many of these periods are also represented in the Tyrrhenian Basin by dark sediment layers rich in organic material (e.g., in Section 4 of Core 3, Section 5 of Core 6 and Section 1 of Core 7). In the sediments of these sections, foraminiferal tests are coated and filled with pyrite, and the clay particles are aggregated into large $(\approx 30 \mu)$ opaque masses. As mentioned previously, an oligotypical planktonic foraminiferal assemblage was recorded in one such dark layer of Section 5, Core 6.

We feel that the sapropels of Core 1, Site 125 are synchronous with the dark layers of Core 3 in the Tyrrhenian Basin and that the sapropels of Core 3 (125) are synchronous with those in the bottom of Core 6 and the top of Core 7 (132).

Other time-synchronous events include major explosive volcanic eruptions (Ninkovich and Heezen, 1965). Correlation based on the measured indices of refraction of the glass shards in discrete tephra layers common to both basins are suggested at two levels (see Figure 11). Undoubtedly, further research will provide many more correlation points, since volcanic activity has been particularly high through much of the Upper Pleistocene.

In summary, more than ten levels of correlation between the two sites are offered. Other points of correlation exist from the comparison of the drilled sections to those obtained within the same basins by piston coring.

\section{Correlations with Piston Cores}

A number of relatively long piston cores have been recovered from the Mediterranean. The ones most carefully investigated so far are those of the Swedish Deep-Sea Expedition (Parker, 1958; Emiliani, 1958; Olausson, 1961, 1965 ) and those from Vema 10 and Robert D. Conrad 9 expeditions of the Lamont-Doherty Geological Observatory (Ryan and Heezen, 1965; Ryan, in press; Herman, 1971a; Karlsson and Berggren, in preparation).

Ryan (in press) offered a preliminary correlation of sixteen piston cores collected along an east-west profile through the Levantine and Ionian basins essentially on the basis of gross lithology including tephra horizons and sapropel layers. These particular lithostratigraphic units have been considered as strictly isochronous throughout the eastern Mediterranean Basin. The cores were correlated to a generalized climatic curve for the Quaternary (Emiliani, 1966) and with the faunal zones distinguished by Ericson et al. (1961) in the Caribbean.

It was stated earlier that the topmost parts of the Quaternary sections at Sites 125 and 132 were not cored. This is particularly evident in the climatic curve for Site 132, which shows a marked cold interval in Section 1 of Core 1 . The problem is to decide how much of the section is missing.

Figure 12 shows a preliminary attempt to match individual strata (tephra layers and sapropels) and climatic intervals between the drill sites and piston cores in the immediate area. Core RC9-195 location at $40^{\circ} 45.2^{\prime} \mathrm{N} ; 11^{\circ}$ $05.6^{\prime} \mathrm{E}$ (2338 meters depth) lies just to the northwest of the Tyrrhenian drill site. Six individual strata of this core can be matched to Core 1 of Site 132 layer for layer. The lower right-hand insert of Figure 12 indicates that the top of Core 1 has an age of 36,000 years. The marked cold interval in Section 1 could thus fall in the last glacial stage (Würm) in agreement with the chronologies of the North Atlantic and Caribbean (Emiliani, 1966; Ericson et al., 1964; Broecker and Van Donck, 1970).

Core RC9-185 location at $34^{\circ} 27.1^{\prime} \mathrm{N} ; 20^{\circ} 06.9^{\prime} \mathrm{E}(2858$ meters depth) lies just to the southwest of Site 125 in the Ionian Basin. A third core location, RC $9-191$ at $38^{\circ} 11.6^{\prime} \mathrm{N}$; $18^{\circ} 02^{\prime} \mathrm{E}$ (2345 meters depth), lies midway between Sites 132 and 125 and just seaward of the type section of Le Castella in Calabria.

Ten lithologic units in Core 185 can be correlated layer for layer to identical strata in Core 191, and eight of these can be continued to Core 1 of Site 132. In addition, the climatic curve for the eastern Mediterranean piston cores (from Ryan, in press) shown in Figure 12 with the numerical stages of Emiliani (1966) and the lettered zonations of Ericson et al. (1961) has a marked similarity to that of the Tyrrhenian drill site. The interpolated time scale based on the paleomagnetic datums of Site 132 matches $\pm 20,000$ years the independent time scale of RC9-185 of Ryan (in press). In fact, the projected U/V boundary in Stage 13 of Site 132 interpolates to exactly the same age as was assigned to it by Ericson and Wollin (1968) - i.e., 375,000 years.

The uppermost core of Site 125 seems to correlate well with the lower part of Core 2 of Site 132. The lithologic matching of a tephra layer between Section 2 of Core 1, Site 125 and Section 4 of Core 2, Site 132 fits perfectly with the previously proposed climatic correlation "i". This arrangement places the first warm peak of Site 125 with Emiliani's Stage 15, just below the U/V boundary. Only one piston core to our knowledge (RC9-182) penetrates below the U/V boundary. However, as of this writing, no firm correlation can be made between the lowermost units of this core and Sections 1, 2, or 3 of Core 1 at Site 125 . Our proposed matching of the top of the Site 125 section in Stage 15 would place this level at about 400,000 years B.P. It is fortunate that the piston cores extend to, and overlap the deep drilling cores, allowing the missing gaps to be filled in with available material from other collections. ${ }^{5}$

\section{Correlation to Pleistocene Section of the Hellenic Trench}

Sites 127 and 128 are located on the floor of the Hellenic Trench (4636 meters) some 210 kilometers to the northeast of Site 125 (See Figure 2). The drill stems at Sites 127 and 128 penetrated a Quaternary section some ten times thicker than that found seaward on the Mediterranean Ridge at Site 125. In fact, the thickness of the Quaternary is not less than 427 meters at Site 127 and 480 meters at Site 128. At the former location, the Quaternary is underlain unconformably by Lower Cretaceous limestones; in the latter, the hole was terminated within the lowermost part of the Pleistocene.

\footnotetext{
${ }^{5}$ The RC9 cores are stored at Lamont-Doherty Geological Observatory and are available for sampling by written request to the curator of the Core Laboratory.
} 
M. B. CITA, M. A. CHIERICI, G. CIAMPO, M. MONCHARMONT ZEI,

S. d'ONOFRIO, W. B. F. RYAN, R. SCORZIELLO

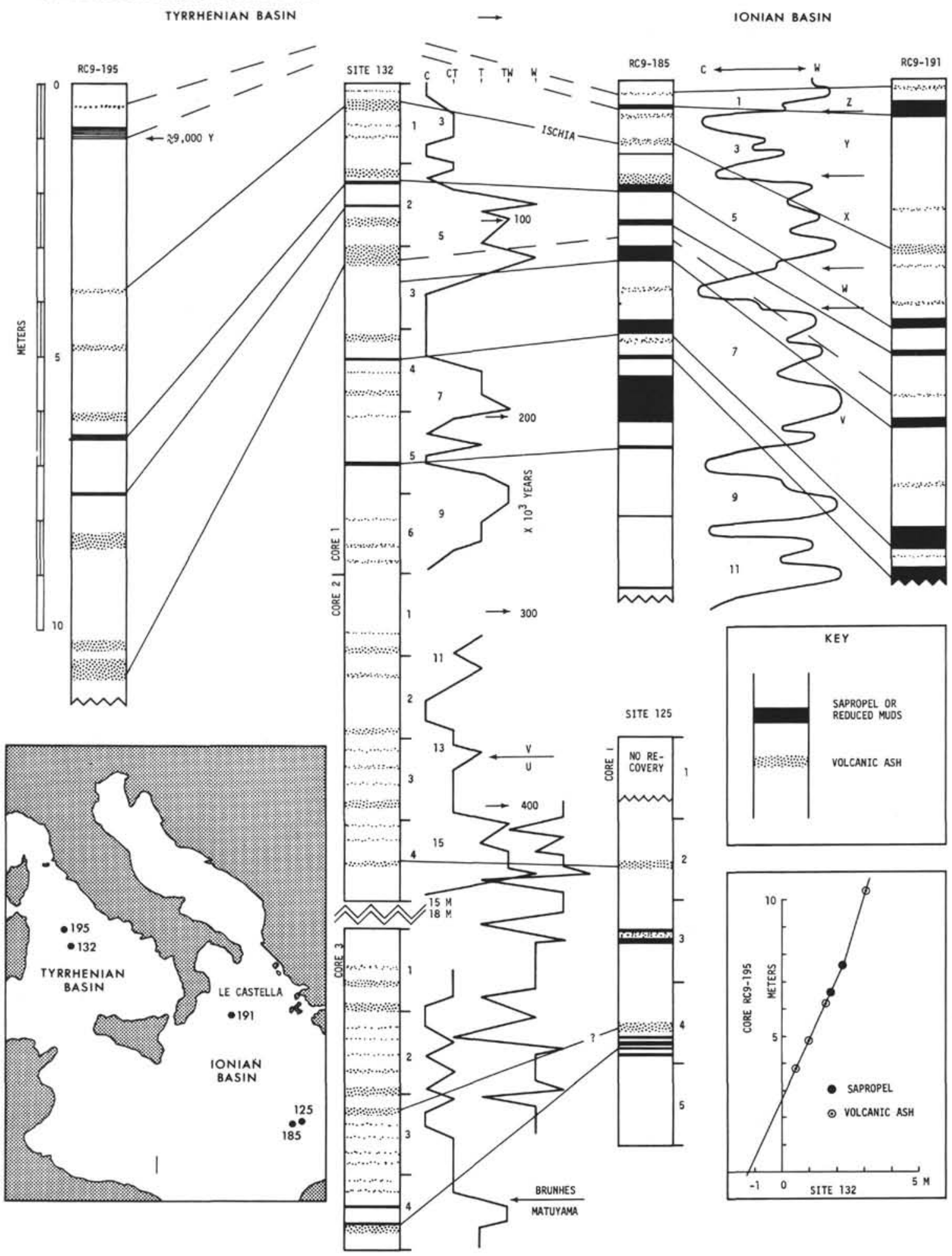

Figure 12. Correlations between the DSDP sites in the Tyrrhenian and Ionian basins and nearby piston cores. The Robert D.

Conrad (Cruise 9 cores were collected in 1965, and are described by Ryan (in press). A correlation between RC9-195 and Core 1 of Site 132 (lower right hand insert) indicates that approximately 1.2 meters from the top of the sediment column were lost at Site 132. The time scale, adjusted to the non-zero age for the top of the sedimentary section is from Foster and Opdyke (1970) and is based on the Brunhes-Matuyama boundary (0.69 my B.P.) near the top of Section 4 of Core 3 at Site 132. Piston Core RC9-185 can be correlated both lithostratigraphically and paleoclimatically to sections at Site 132, thus filling in most of the missing gap at Site 125. The inferred stage numbers for the warm peaks are from Emiliani (1966) and the lettered zones are from Ericson et al., (1961). 
Both lithostratigraphic and biostratigraphic correlations have been attempted between the trench and ridge cores (Figure 13). The lithostratigraphic correlations are based on the occurrence of sapropelitic layers at two different intervals and a single tephra layer found at all three sites. The upper sapropelitic interval ("Brunhes-Matuyama sapropels," as named by Ryan and Cita in Chapter 47.5) occurs from 99 to 116 meters below the sea floor in the Hellenic Trench (Cores 5 and 6, Site 127; Cores 3 and 4, Site 128) and in Core 1, Site 125 (Mediterranean Ridge). The lower sapropelitic interval ("Matuyama pre-Jaramillo sapropels") occurs from 304 to 383 meters below the sea floor in the Hellenic Trench (Cores 13 and 14, Site 127; Cores 8, 9 and 10, Site 128) and in Core 3, Site 125.

Biostratigraphically, a correlation is possible only on the basis of calcareous nannofossils. The nannofossils allow an easy distinction of the Gephyrocapsa oceanica Zone, overlying a Coccolithus doronicoides and/or a Pseudoemiliania lacunosa Zone characteristic of the earliest Pleistocene. The former zone is present in Cores 1-2, Site 125, Cores 1-9, Site 127, and Cores 1-6, Site 128. The Pseudoemiliania lacunosa Zone is present in Cores 3 and 4, Site 125; Cores 12-14, Site 127; and Cores 7-11, Site 128 (see biostratigraphic summary in Chapter 9 of this volume).

Both correlations are in agreement. The upper sapropelitic interval ("Brunhes-Matuyama sapropels") falls in the Gephyrocapsa oceanica Zone, and the lower sapropelitic interval ("Matuyama pre-Jaramillo sapropels") falls in the Pseudoemiliania lacunosa Zone at all three sites.

A correlation based on paleoclimatic events, as revealed by planktonic foraminifera, is not possible because the distribution of these fossil remains in the sediments filling the Hellenic Trench is controlled considerably by sedimentary processes and does not allow, at this time, a reliable reconstruction of paleoenvironmental conditions.

\section{Correlation to the Equatorial Atlantic}

The inferred climatic curves of Figures 4, 5, and 11, having been cross-correlated to each other and to nearby piston cores, have subsequently been combined into a single generalized climatic curve for the Quaternary of the Mediterranean as a whole. The curve shown in Figure 14 has been normalized to an absolute time scale based on five paleomagnetic datums: the Brunhes-Matuyama boundary, top and bottom of the Jaramillo event, top of the Olduvai event (all at Site 132), and the bottom of the Olduvai at Site 125 .

The Mediterranean curve in Figure 14 is plotted against a recently published "total fauna" climatic curve obtained from long piston cores in the equatorial Atlantic Ocean (Ruddiman, 1971). Since Ruddiman has cross-correlated his curve to published curves from the Antarctic (Kennett, 1970), Caribbean (Emiliani, 1966), North Atlantic (McIntyre and Jantzen, 1969), and Equatorial Pacific (Hays et al., 1969, and Ericson and Wollin, 1968), there is no need to present all these correlations here. However, it suffices to say that the correlation of the Mediterranean generalized curve to that of Ruddiman (1971) is marked.

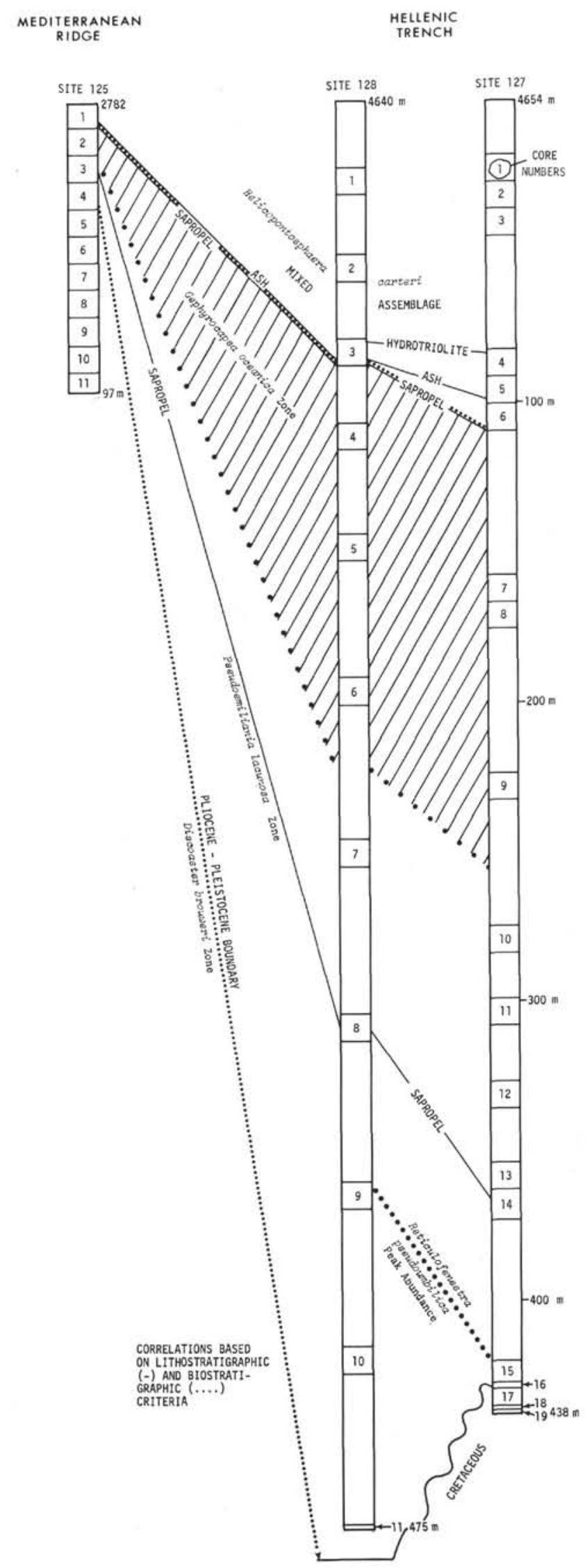

Figure 13. Correlations between Site 125 on the Mediterranean Ridge and Sites 127, 128 in the Hellenic Trench. 
GENERAL IZED CLIMATIC CURVES

COLD

WARM

\section{EQUATORIAL ATLANTIC MEDITERRANEAN}

M.Y.

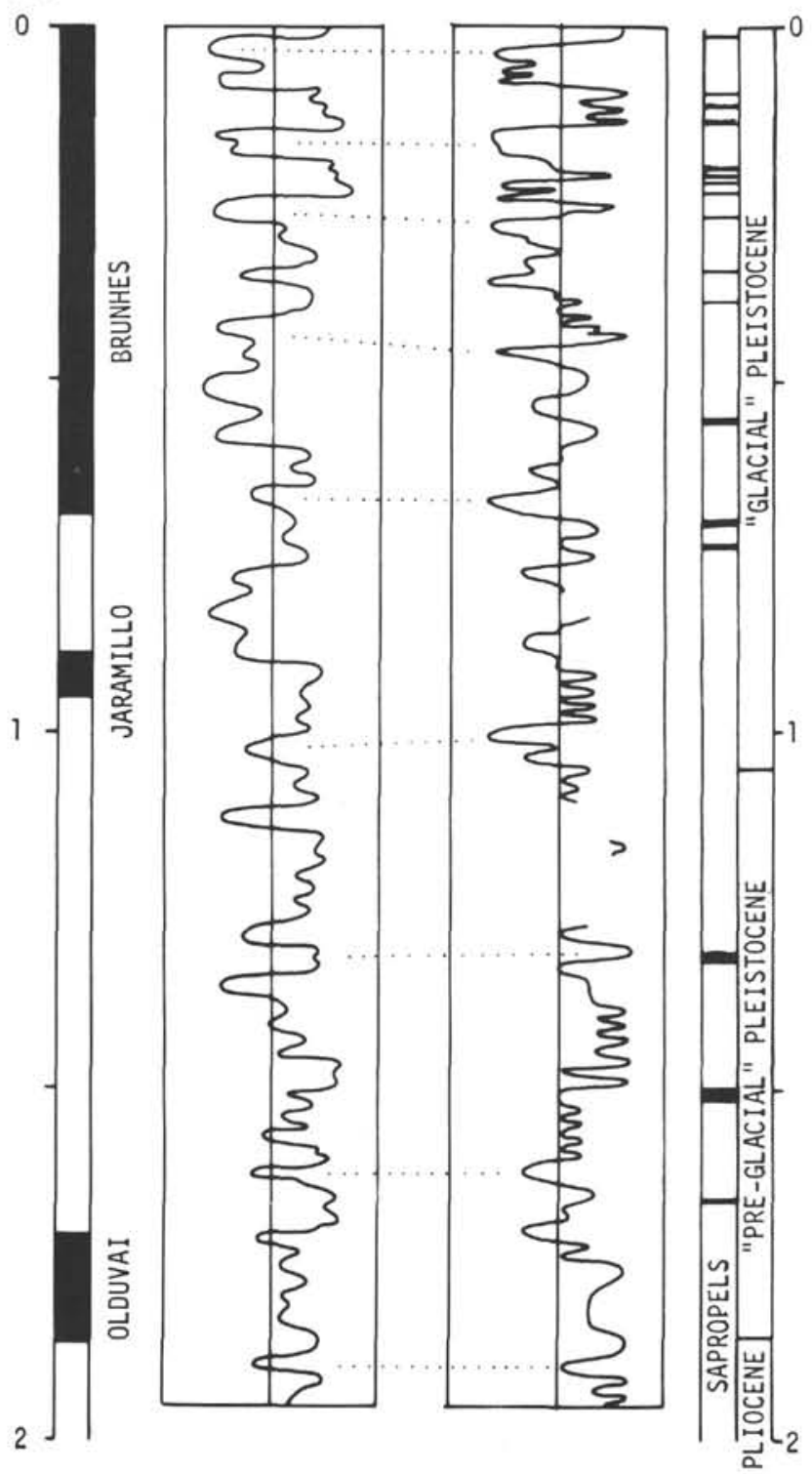

Figure 14. Generalized climatic curves for the equatorial Atlantic and the Mediterranean. The Mediterranean curve has been constructed by weighing all the data from the various drill cores and piston cores and has been normalized to the geomagnetic time scale. The equatorial Atlantic curve is a "total fauna" assessment of Ruddiman (1971). The dotted lines are suggested levels of correlation. The heavy bars on the right column show levels of sapropelitic sedimentation in the Mediterranean, and seem to correspond to periods of marked warming.

For both curves we note from top to bottom:

1) The Brunhes normal epoch is characterized by a number of cold and warm episodes, with rapidly changing climatic conditions (glacial and interglacial periods)
2) The Brunhes-Matuyama boundary falls along the cooling trend from a notable warm interval.

3) The interval between the Brunhes-Matuyama boundary and the Jaramillo event is characterized by a cold episode (glaciation?).

4) The Jaramillo event falls in temperate-warm interval.

5) The Matuyama pre-Jaramillo epoch is characterized by fluctuating climatic conditions ranging from temperate to warm, with very short and limited excursions to "cold", mainly in the upper part.

6) There is no evident cooling at the PliocenePleistocene boundary.

\section{Correlation to Glacial Terraces}

The succession of Tiraspol (Moldavia, USSR) has been recently proposed as reference section for the continental Pleistocene of Europe (see Nikiforova et al., 1971). This section, visited by one of us, consists of continental deposits, mainly alluvial, some of which represent glacial outwash. A number of terraces along the Dnieper River near Tiraspol have been investigated; there are twelve in all. Terrace XII is the highest and the oldest. Terrace V yielded a very rich mammalian fauna, which includes Mammuthus trogontherii trogontherii, Bison, Capreolus, Dicrorhinus, and Ursus. This terrace is correlated with the Mindel glaciation and lies very near the Brunhes-Matuyama boundary. In fact, the deposits of Terraces I-V have been found to have a normal magnetization, while the deposits of Terraces VI-VIII (at least) have reversed magnetization.

This direct correlation of continental deposits with the paleomagnetic stratigraphy is considered very important and agrees well with our evidence. In fact, the BrunhesMatuyama boundary, as identified in the generalized climatic curves, lies on the cooling trend into a prominent cold interval. Other distinct cold intervals have been recorded below this boundary and may possibly be correlated with the Günz and Donau(?) glaciations.

The marked cold intervals observed within the Brunhes epoch in the Tyrrhenian Basin and Ionian Basin piston cores, should correspond to the Würm, Riss and Mindel glaciations.

Similar important climatic changes within the Brunhes normal epoch are recorded from all the deep-sea sections (piston cores) investigated both paleontologically and paleomagnetically (see Berggren et al., 1967; Hays et al., 1969; Ruddiman, 1971, inter alia).

The marked cooling trend superimposed on the Mediterranean curves suggests to us that the glacial Pleistocene of Europe was limited to the upper part of the Quaternary, in agreement with previously stated opinions of Emiliani (1955) and Selli (1967).

We also note that the levels of sapropel mud, recording the periodic stagnations of the Mediterranean, lie near the warm peaks on the generalized curve. Our new finding is that the sapropels are not limited to the glacial Pleistocene alone, but also occur in the lower Pleistocene. Perhaps the eustatic sea level control exerted on the Mediterranean circulation, originally proposed by Olausson $(1961,1965)$, is indeed important, and the Mediterranean sediments are faithfully recording high latitude glaciations, which themselves never penetrated into the Mediterranean region. 
This is consistent with the findings of a number of erosional phases in central Italy near Rome (Ambrosetti, 1967; Bonadonna and Bigazzi, 1970). The Flaminian erosional phase, dated at $\approx 700,000$ B.P. by Everden and Curtis (1965), has been correlated with the Mindel glaciations, in agreement with the paleomagnetic chronology inferred from the Tiraspol terraces.

\section{SUMMARY OF MAJOR CONCLUSIONS}

1) A boundary which we recognize as the limit between the Pliocene and Pleistocene, and which is time-equivalent to the base of the Calabrian in type sections in Italy, has been identified in the DSDP cores from the Tyrrhenian and Ionian basins.

At Site 125 the Pliocene-Pleistocene boundary could be narrowed to a one-meter interval in Core 4 according to three criteria: the first occurrence of Globoratalia truncatulinoides, the extinction horizon of Discoaster brouweri, and a change from reverse to normally magnetized sediment, i.e., the base of the Olduvai event.

At Site 132, the boundary could be placed only on the basis of the nannofossil stratigraphy.

2) No definite biostratigraphic events concerning planktonic foraminifera may be recognized in either the late or early Quaternary. The distribution of planktonic foraminifera is controlled by ecologic factors (superficial water temperature in the photic zone, salinity, and possibly changes in the structure of the thermocline) and appears to be cyclically repeated. The only species which disappear in the lower part of the Pleistocene are Globigerinoides cf. fistulosus and Globorotalia tosaensis. Both forms are rare and their record is not continuous. Inasmuch as the information on their total range is considered insufficient, they are unsuitable for the definition of a biohorizon or zonal boundary.

Globorotalia truncatulinoides, the range of which is limited downwards at Site 132, cannot be used to subdivide the Quaternary succession, since its range is known to be longer in other locations within the Mediterranean. This species appears to be highly sensitive not only to changes in temperature, but also to other ecological factors.

3) Coccoliths, unlike foraminifera, do allow a biostratigraphic subdivision of the Quaternary. A lowermost Pseudoemiliania lacunosa Zone or Coccolithus doronicoides Zone, which was proven time-synchronous in the Ionian and Tyrrhenian basins, can be recognized. Other zonal markers include Pseudoemiliania lacunosa, Gephyrocapsa oceanica, and Emiliania huxleyi.

4) Although the preliminary data are in a great part ambiguous, a paleomagnetic record has been deciphered for parts of the sedimentary sections. All reversal boundaries of the Quaternary have been recognized. The mean rate of pelagic sedimentation is $2.5 \mathrm{~cm} / 10^{3} \mathrm{y}$ for Site $125,3.5$ $\mathrm{cm} / 10^{3} \mathrm{y}$ for the last one million years of the Quaternary of Site 132 , and $4.0 \mathrm{~cm} / 10^{3} \mathrm{y}$ for the interval from 1 to $2.5 \mathrm{my}$.

5) The Quaternary record at Sites 125 and 132 fills a gap in our information concerning the history of the Mediterranean basins where the marine stages for the Quaternary have historically been defined. In fact, even the longest piston cores investigated so far have not, without major unconformities, reached pre-glacial deposits. The record can be subdivided in two parts: an upper part characterized by important climatic changes, with definitely cold intervals; and a lower part with less pronounced fluctuations, devoid of definitely cold intervals.

The stratigraphic record we have tried to decipher confirms the hypothesis put forward by Selli (1967) based on a number of extrapolations. It agrees well with the opinions expressed that not only the type Calabrian (Emiliani, Mayeda and Selli, 1961), but also the type Sicilian at Ficarazzi (see Emiliani, Gianotti and Mayeda, 1961; Gradstein, 1970, represent preglacial deposits. Furthermore, it seems in good agreement with the evidence given by deep-sea cores outside the Mediterranean, coming from a true oceanic realm (see Berggren et al., 1967; Hays et al., 1969; Hays and Berggren, 1971; Ruddiman, 1971; and Olausson, 1960) and from conclusions based on the interpretation of continuous seismic reflection profiles (Ryan, in press).

6) The distribution of benthic foraminifera and other fossil remains occurring in the cores investigated suggests that neither the Mediterranean Ridge nor the central Tyrrhenian Basin experienced important bathymetric changes during Quaternary times. If any major change in the water depth at the sites of deposition and/or in the regional sedimentary environment should have occurred during the $1.8 \mathrm{my}$ represented by the Quaternary successions continuously cored, this change should have resulted in some observable anomaly in the extremely abundant fossil assemblages investigated. However, such evidence was not found. The most notable perturbation concerns intermittent volcanic activity, which appears to become more and more important as we approach the present time.

The above conclusion concerning the paleobathymetry is very important in connection with contemporary hypotheses about the origin and evolution of the Tyrrhenian Basin (see Selli and Fabbri, 1971). Our data indicate that the Tyrrhenian Basin was as deep at the beginning of the Quaternary as it is at present.

7) The Quaternary record at Site 125 in the Ionian Basin has been correlated physically and paleoclimatically with the sedimentary section recovered at Site 132 in the Tyrrhenian Basin and with the very thick Pleistocene successions penetrated in the Hellenic Trench (Sites 127 and 128). Approximately 400,000 years of sedimentary history are missing at the top of the recovered column of Site 125; however, this interval can be filled in from a nearby piston core (RC9-185), which in turn can be correlated to the late glacial sections of Site 132 .

8) The sapropel cycles interpreted by Olausson (1961) as glacio-eustatically controlled, are present in sediments deposited prior to the onset of glaciation in the circumMediterranean area. The thickest sapropel layer recovered at Site 125 (Core 3-4), which suggests a severe and persistent period of stagnation, belongs to the preglacial Pleistocene.

The suggestion that the sapropel layers occur along the warming trends of the climate curve (Ryan, in press) is not contradicted by the present data. However, it is pointed out that the changes observed in the planktonic foraminiferal 
assemblages and related to periods of stagnation appear to be even more important in the preglacial Pleistocene (which is here investigated for the first time) than in the glacial Pleistocene already known from piston cores. The faunal anomalies observed in the sapropels and in certain layers rich in volcanic components make it difficult at the present time to distinguish between ecological responses to surface water temperature alone and responses to other oceanographic parameters such as salinity, degree of ventilation, supply of nutrients, etc. It is our wish that the data presented here may be useful in future research geared to deciphering this interesting problem.

\section{ACKNOWLEDGMENTS}

The present report has been prepared in a very short period of time thanks to the generous help of a number of Italian micropaleontologists who volunteered to investigate the exceptionally interesting material obtained from the subsurface of the Tyrrhenian and Ionian basins.

M.B.C. wishes to sincerely thank AGIP, Direzione Mineraria; Professor Vittorio Vialli, Director of the Institute of Geology, University of Bologna; and Professor A. Maria Maccagno, Director of the Institute of Paleontology, University of Naples, for encouraging Dr. M. A. Chierici, Dr. S. d'Onofrio and the Napoli team to take part in the program. Financial support has been provided by Consiglio Nazionale delle Ricerche of Italy, Comitato 05.

Most of the investigations on the foraminiferal faunas and all the graphic documentation on the Site 132 samples have been made at the University of Naples, under the guidance of Prof. M. Moncharmont Zei.

W.B.F.R. wishes to acknowledge financial support from the Oceanographic Section of the U.S. National Science Foundation under grant GA27281 and from the Office of Naval Research through contract N00014-67-A-0108-0004. Conversations with William F. Ruddiman, Douglas Tolderlund, Tsunemasa Saito, William Berggren, William Lowry, Billy Glass, David Ericson and Goesta Wollin have been most valuable. Lamont-Doherty Geological Observatory No. 1862 .

\section{REFERENCES}

Ambrosetti, P. B., 1967. Revisione dei dati sul PlioPleistocene di Roma. Atti Accad. Gioenia Catania sVI $18,33$.

Bandy, O. L., 1960. The geologic significance of coiling ratios in the foraminifer Globigerina pachyderma (Ehrenberg). J. Paleontology. 34 (4), 671.

Bandy, O. L. and Wilcoxon, J. A., 1970. The PliocenePleistocene boundary, Italy and California. Bull. Geol. Soc. Am. 81, 2939.

Banner, F. T. and Blow, W. H., 1965. Progress in the planktonic foraminifera biostratigraphy of the Neogene. Nature. 208 (5016), 1164.

Bayliss, D. D., 1969. The distribution of Hyalinea baltica and Globorotalia truncatulinoides in the type Calabrian. Lethaia. 2, 113.

Benson, R. H., 1969. Preliminary report on the study of abyssal ostracodes. The Taxonomy, Morphology and Ecology of Recent Ostracodes. Edinburgh. (Oliver and Boyd) 475 .

Berger, W., 1970. Planktonic foraminifera: selective solution and the lysocline. Marine Geol. 8 (2), 111.

Berggren, W. A., 1968. Micropaleontology and the PliocenePleistocene boundary in a deep-sea core from southcentral North Atlantic. Gior. Geol. Ser. 2. 35 (2), 291.
Berggren, W. A., Phillips, J. D., Bertels, A. and Well, D., 1967. Late Pliocene-Pleistocene stratigraphy in deep-sea cores from the south-central North Atlantic. Nature. 216, 253.

Blow, W. H., 1969. Late middle Eocene to Recent planktonic foraminiferal biostratigraphy. In Proc. First Intern. Conf. Plank. Microfossils. Brill, (Ed.) I, 199.

Bolli, H. M., 1970. The foraminifera of Sites 23-31, Leg 4. In Bader, R. G., Gerard, R. D. et al., 1970. Initial Reports of the Deep Sea Drilling Project, Volume IV. Washington (U.S. Government Printing Office). 577.

Boltovskoy, E., 1969. Living planktonic foraminifera at the $90^{\circ} \mathrm{E}$ meridian from the Equator to the Antarctic. Micropaleontology 15 (2), 237.

Bonadonna, F. P. and Bigazzi, G., 1970. Studi sul Pleistocene del Lazio, VIII - Datazione di tufi intertirreniani della zona di Cerveteri(Roma) mediante il metodo delle tracce di fissione. Boll. Soc. Geol. Ital. 89, 463.

Broecker, W. S. and Van Donck, J., 1970. Insolation changes, ice volumes and the $\mathrm{O}^{18}$ record in deep sea cores. Rev. Geophys. Space Phys. 8, 169.

Cati F. et al., 1968. Biostratigrafia del Neogene Mediterraneo basata sui foraminiferi planctonici. Boll. Soc. Geol. Ital., 87, 491.

Chierici, M. A., Busi, M. T. and Cita, M. B., 1962. Contribution á une étude écologique des Foraminiféres dans la mer Adriatique. Rev. Micropal. 5 (2), 123.

Cifelli R. and Smith, R. K., 1970. Distribution of Planktonic foraminifera in the vicinity of the North Atlantic current. Smithsonian Contrib. Paleobiology. 4.

Cita, M. B., Premoli Silva, I. and Rossi, R., 1965. Foraminiferi planctonici del Tortoniano-tipo. Riv. Ital. Paleontol. 71 (1), 217.

d'Onofrio, S., 1970. Ricerche sui Foraminiferi nei fondali antistanti il delta del Po. Giorn. G. 36 (1), 283.

Emiliani, C. 1955. Pleistocene temperature variations in the Mediterranean. Quaternaria. 3, 109. 1958. Paleotemperature analysis of Core 280 and Pleistocene correlations. J. Geol. 66, 264.

1961. Cenozoic climatic changes as indicated by the stratigraphy and chronology of deep-sea cores of Globigerina-ooze facies. New York Acad. Sci. 95, 521. 1966. Paleotemperature analysis of the Caribbean cores P6304-8 and P6304-9 and a generalized temperature curve for the last 425,000 years. J. Geol. 74 (6), 109.

, 1971. Isotopic paleotemperatures and shell morphology of Globigerinoides rubra in the type section for the Pliocene-Pleistocene boundary. Micropaleontology. 17, (2), 233.

Emiliani, C., Gianotti, A. and Mayeda, T., 1961. Analisi isotopica dei foraminiferi Siciliani delle argille di Ficarazzi, Palermo. Quaternaria 5, 135.

Emiliani, C., Mayeda, T. and Selli, R., 1961. Paleotemperature analysis of the Plio-Pleistocene section at Le Castella, Calabria, southern Italy. Bull. Geol. Soc. Am. 72,679 .

Eriksson, K. G., 1965. The sediment Core No. 210 from the western Mediterranean Sea. Rept. Swedish Deep-Sea Exped., 1947-1948. 8, fasc. 5, 7, 393.

Ericson, D. B., Ewing. M., Wollin, G. and Heezen, B. C., 1961. Atlantic deep-sea sediment cores. Bull. Geol. Soc. Am. 72193.

Ericson, D. B., Ewing, M. and Wollin, G., 1963. PliocenePleistocene boundary in deep-sea sediments. Science. $139,727$.

1964. The Pleistocene epoch in deep-sea sediments. Science. 146, 723 . 
Ericson, D. B. and Wollin, G., 1968. Pleistocene climates and chronology in deep-sea sediments. Science. 162, 1227.

Everden, J. F. and Curtis, G. H., 1965. The PotassiumArgon dating Late Cenozoic rocks in East Africa and Italy. Curr. Anth. 6 (4), 343.

Finetti, I., Morelli, C. and Zarudzki, E.F.K., 1970. Reflection seismic study of the Tyrrhenian sea. Bull. di Geofisica Teorica ed. Appl. 12 (48), 311.

Foster, J. H. and Opdyke, N. D., 1970. Upper Miocene to Recent magnetic stratigraphy in deep-sea sediments. $J$. Geophys. Res. 75, 4465 .

Gignoux, M., 1910. Sur la Classification du Pliocéne et du Quaternaire dans l'Italie du Sud. C. R. Acad. Sci., Paris. 150,841 .

1913. Les formations marines pliocènes et quaternaires de l'Italie du sud et de la Sicile. Ann. Un. Lyon N.S., 36, 1.

Glass, B., Ericson, D. B., Heezen, B. C., Opdyke, N. D. and Glass, J. A., 1967. Geomagnetic reversals and Pleistocene chronology. Nature. 216 (5114), 437.

Gradstein, F. M., 1970. Foraminifera from the type Sicilian at Ficarazzi, Sicily (Lower Pleistocene). Koninkl. Ned. A kad. Wetenschnap Proc., B. 73, (4) 1.

Grazzini-Vergnaud, C. and Herman-Rosenberg, Y., 1969. Etude paleoclimatique d'une carotte de Méditerranée orientale. Rév. Géog. Physique et Géol. Dynamique. 11 (3), 279.

Harrison, C.G.A. and Funnell, B. M., 1964. Relationship of paleomagnetic reversals and micropaleontology in two late Cenozoic cores from the Pacific Ocean. Nature. 204, 566.

Hay, W. W. and Boudreaux, J. E., 1968. Calcareous nannofossils in the Submarex core, Nicaragua Rise, Caribbean Sea; Le Castella, Calabria; and the age of the Pliocene-Pleistocene Boundary. Giorn. Geol. Ser. 2, 35 (2), 143

Hays, J. D. and Opdyke, N. D., 1967. Antarctic Radiolaria, magnetic reversals and climatic changes. Science. 158, 1001.

Hays, J. D. and Berggren, W. A., 1971. Quaternary Boundaries and Correlations. In The Micropaleontology of the Oceans. Cambridge (Cambridge Univ. Press), 669.

Hays, J. D., Saito, T., Opdyke, N. D. and Burckle, L. H., 1969. Pliocene-Pleistocene sediments of the equatorial Pacific: their paleomagnetic, biostratigraphic and climatic record. Bull. Geol. Soc. Am. 80, 1481.

Herman, Y., 1971a. Quaternary climatic changes in the eastern Mediterranean as recorded by pteropods and planktonic foraminifera. Proc. Second Plank. Conf. Rome. II, 611 .

1971b. Late Quaternary 'eastern Mediterranean sediments (Abstract). Proc. Intern. 8th Sediment. Congr. Heidelberg. 41.

Hesse, R., von Rad, V. and Fabricius, V. F., 1971. Holocene sedimentation in the Strait of Otranto between the Adriatic and Ionian Seas (Mediterranean). $J$. Marine Geol. 10, 293.

Iaccarino, S., 1967. Ricerche sui Foraminiferi contenuti in sei carote prelevate nel Mar Ligure (La Spezia). Boll. Soc. Geol. Ital. 86, 59.

Kennett, J. P., 1970. Pleistocene paleoclimates and foraminiferal biostratigraphy in subantarctic deep-sea cores. Deep-Sea Res. 17, 125.

McIntyre, A., Bé, A. W. H. and Preikstas, R., 1967. Coccoliths and the Plio-Pleistocene boundary. Progress in Oceanography. New York (Pergamon Press), 43.
McIntyre, A. and Jantzen, R., 1969. Paleogeography and stratigraphy of coccolith carbonate in the Pleistocene North Atlantic (Abstract). Proc. 7th INQUA Congr. II, 68.

Moncharmont Zei, M., 1964. Studio ecologico sui Foraminiferi del Golfo di Pozzuoli. Pubbl. Staz. Zool. Napoli, $34,160$.

Morelli, C., 1970. Physiography, gravity, and magnetism of the Tyrrhenian Sea. Bull. Geofis. Teorica ed Appl. 12 (48), 275

Nikiforova, K. V. et al., 1971. The Pleistocene of Tiraspol. In Acad. Sci., USSR, Geol. Inst. Nikiforova, K. V. (Ed.). Moldavia, Kishinev, 1.

Ninkovich, D. and Heezen, B. C., 1965. Santorini tephra. Proc. 17th Symp. Colston Res. Soc. London (Butterworths Sci. Publ.), 413.

Olausson, E., 1960. Studies of deep-sea cores. Rept. Swedish Deep-Sea Exped. 1947-1948. 7, 229.

1961. Studies of deep-sea cores, Rept. Swedish Deep-Sea Exped. 1947-1948. 8, 229.

1965. Evidence of climatic changes in North Atlantic deep-sea cores. Progress in Oceanography. New York, (Pergamon Press), 3, 221.

Olsson, R. K. and Goll, R., 1970. Biostratigraphy. In McManus, D. A. and Burns, R. E. et al., 1970. Initial Reports of the Deep Sea Drilling Project, Volume V. Washington (U.S. Government Printing Office). 557.

Parker, F. L., 1958. Eastern Mediterranean foraminifera. Rept. Swedish Deep-Sea Exped. 1947-1948. 8, 219.

1967. Late Tertiary Biostratigraphy (planktonic foraminifera) of tropical Indo-Pacific deep-sea cores. Bull. Am. Paleontology. 52,115.

Pastouret, L., 1970. Etude sedimentologique et paleoclimatique de carottes prelevees en Mediterranee orientale. Tethys. 2, (1), 227.

Puri, H. S., Bonaduce G. and Gervasio, A. M., 1969. Distribution of Ostracoda in the Mediterranean. The Taxonomy, Morphology and Ecology of Recent Ostracoda. Edinburgh. 356.

Riedel, W. R., Parker, F. L. and Bramlett, M. N., 1963. "Pliocene-Pleistocene" boundary in deep-sea sediments. Science. 140, 1238.

Ruddiman, W. F., 1971. Pleistocene sedimentation in the equatorial Atlantic: Stratigraphy and faunal paleoclimatology. Bull. Geol. Soc. Am. 82, 283.

Ruddiman, W. F., Tolderlund, D. S. and Bé, A. W. H., 1970. Foraminiferal evidence of modern warming of the North Atlantic Ocean. Deep-Sea Res. 17, 141.

Ruggieri, G. and Selli, R., 1950. Il Pliocene e il post-Pliocene dell 'Emilia. Intern. Geol. Congr., 18th. Sess. Great Britain. 9, 85.

Ryan, W. B. F., Late Quaternary Stratigraphy of the Eastern Mediterranean. Proc. 7th Intern. Sediment. Congr. (In press).

Ryan, W. B. F. and Heezen, B. C., 1965. Ionian Sea submarine canyons and the 1908 Messina turbidity current. Bull. Geol. Soc. Am. 76, 915.

Selli, R., 1967. The Pliocene-Pleistocene boundary in Italian marine sections and its relationship to continental stratigraphies. Progress in Oceanography. New York (Pergamon Press). 4, 67.

Selli, R. and Fabbri, A., 1971. Tyrrhenian: a Pliocene deep sea. Accad. Nazl. dei Lincei, Rend. Cl. Sc. Fis., Mat., Nat. 50 (5), 104

Thiede, J., 1971. Planktonische Foraminiferen in Sedimenten vom Ibero-Marokkanischen Kontinentalrand. Dissertation, Kiel, 90 pp. 
M. B. CITA, M. A. CHIERICI, G. CIAMPO, M. MONCHARMONT ZEI, S. d'ONOFRIO, W. B. F. RYAN, R. SCORZIELLO

Todd, R., 1958. Foraminifera from western Mediterranean deep-sea cores. Rept. Swedish Deep-Sea Exped. 19471948. 8 (2), 167

Tressler, W. L., 1941. Geology and biology of North Atlantic deep-sea cores between Newfoundland and
Ireland. Ostracoda. U.S. Geol. Surv. Prof. Paper. 4, 95.

Wezel, F. C., 1968. Le cenozone del Pliocene superiorePleistocene inferiore in Sicilia e Lucania. Giorn. Geol., Ser. 2, 35 (3), 437. 

Figure $1 \quad$ Globigerina praedigitata Parker. Spiral view; $\times 155$. Site 132-3-4, 61-63 cm. Pleistocene of the Tyrrhenian Basin.

Figure 2 Detail of Figure 1 showing the highly perforate surface and a number of coccoliths filling the depressed areas; $\times 2760$.

Figure 3 Globigerina praedigitata Parker. Umbilical view; $\times 175$. Sample DSD $=132-6-1,88-90 \mathrm{~cm}$. Lower Pleistocene of the Tyrrhenian Basin.

Figure 4 Detail of the surface of Globigerina praedigitata (see Figure 3) showing the cancellate surface, $\times 2760$.

Figure $5 \quad$ Globigerina digitata Brady. Umbilical view of a well developed specimen, showing radially elongated last and penultimate chambers and large umbilical aperture with apertural lip; X120. Sample 132-3-4, 71-73 $\mathrm{cm}$. Pleistocene of the Tyrrhenian Basin. 


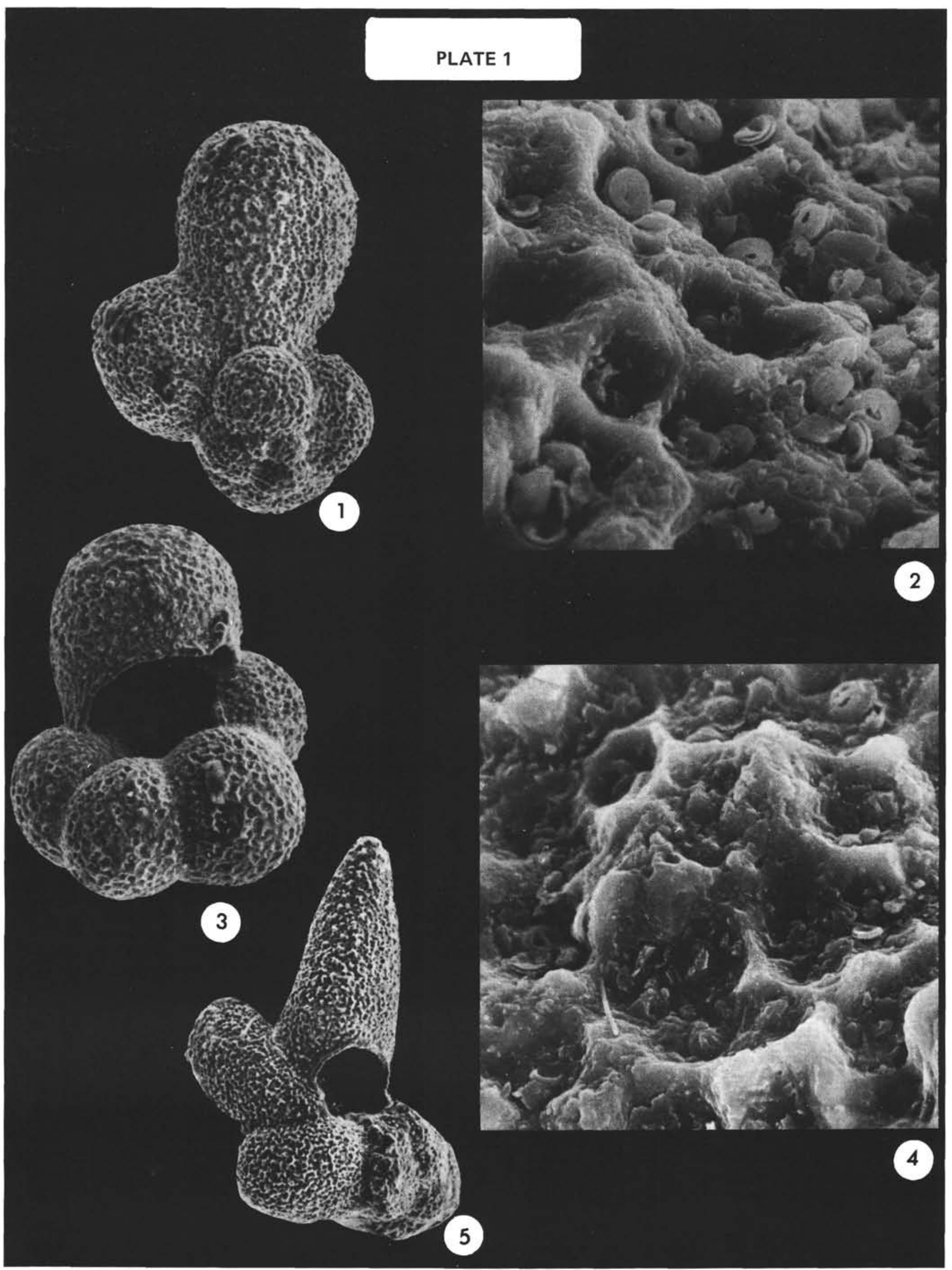


PLATE 2

Figure $1 \quad$ Globigerina eggeri Rhumbler. Spiral view; $\times 140$. Sample DSDP 132-1-4, 49-51 cm. Late Quaternary of the Tyrrhenian Basin.

Figure 2 Detail of Figure 1 showing the highly spinose surface and numerous pores; $\times 1000$.

Figure 3 Globigerina eggeri Rhumbler. Umbilical view; $\times 140$. Sample DSDP 132-1-4, 49-51 cm.

Figure 4 Detail of Figure 3 showing the wide umbilical aperture and the abortive final chamber, which has a less spinose surface than the preceding chambers; $\times 425$. 


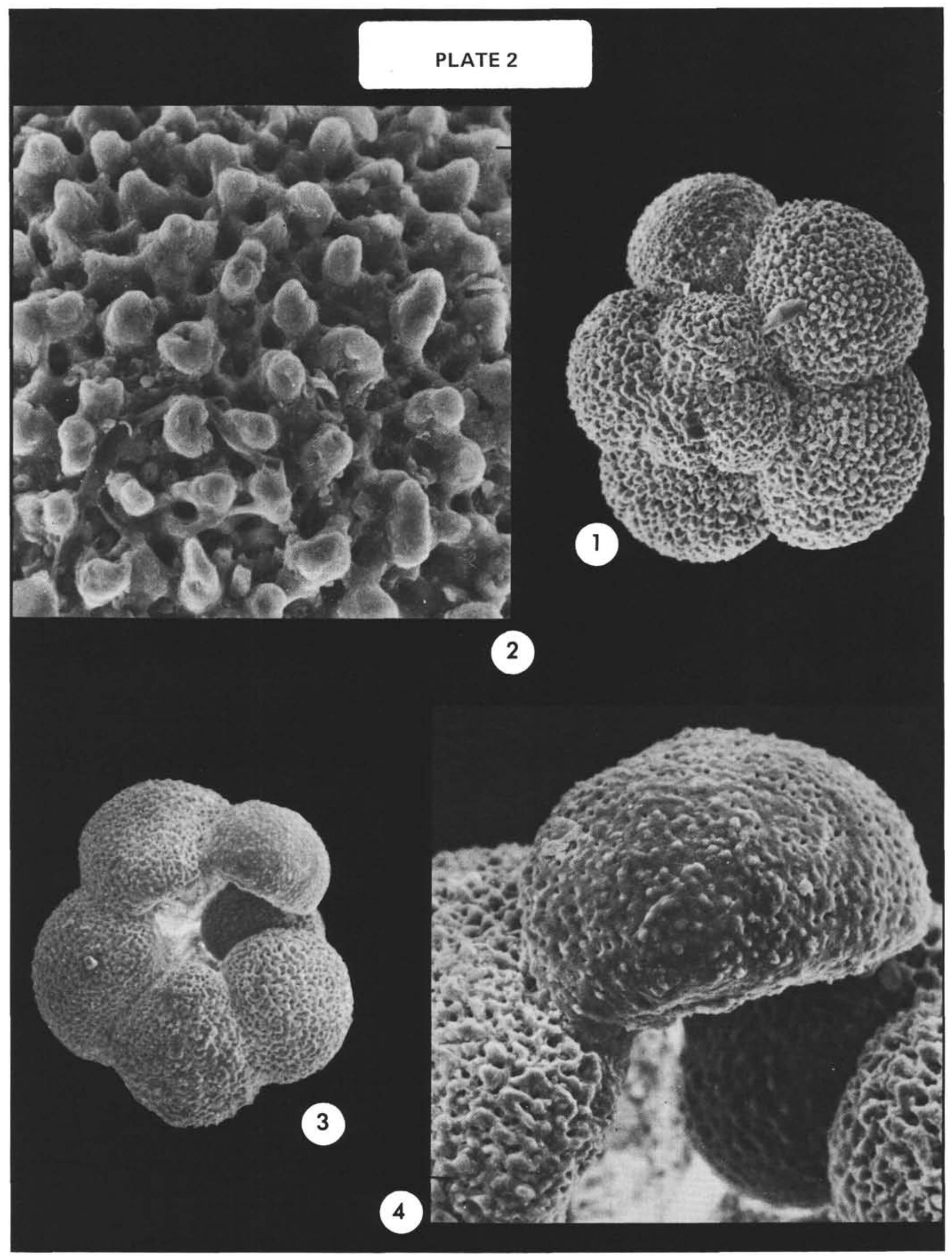




\section{PLATE 3}

Figure $1 \quad$ Globigerina quinqueloba Natland. Spiral view; $\times 260$. Sample DSDP 132-3-3, 114-116 cm. Quaternary of the Tyrrhenian Basin.

Figure 2 Globigerina quinqueloba Natland. Umbilical view; $\times 300$. Sample DSDP 132-3-3, 114-116 cm. Quaternary of the Tyrrhenian Basin.

Figure 3 Detail of Figure 1, showing the early whorls; $X 450$.

Figure 4 Detail of Figure 2 showing the pores of the last formed chamber and the apertural lip; $\times 750$.

Figure 5 Detail of Figure 2 showing the umbilical aperture; $\times 750$. 


\section{PLATE 3}

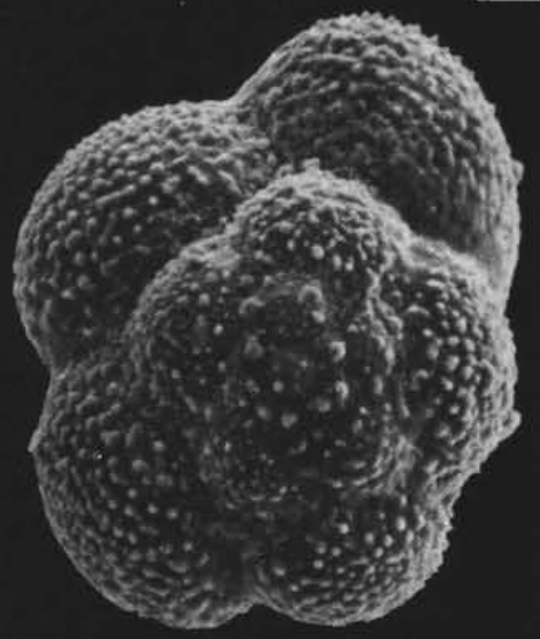

(1)
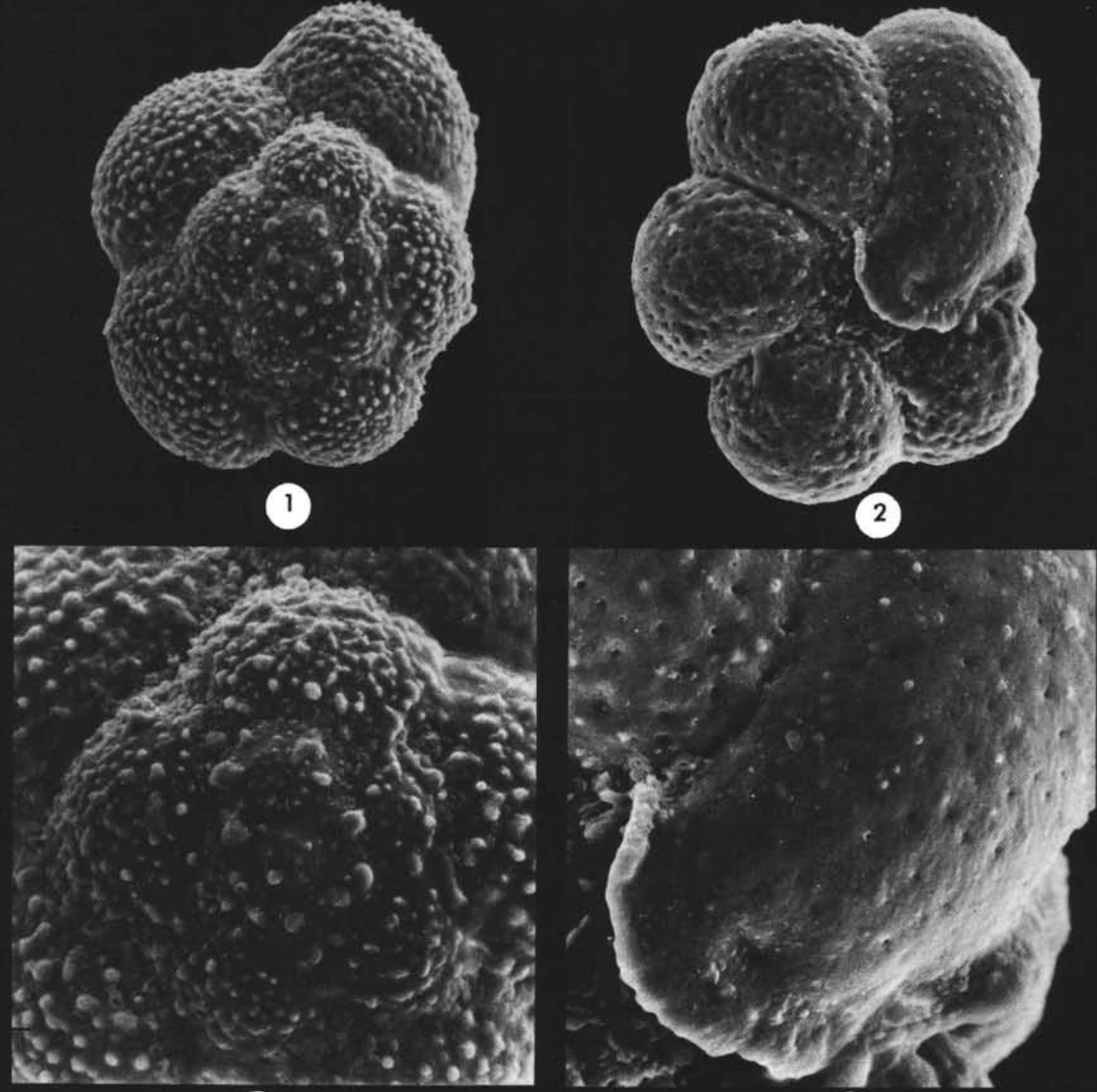

3

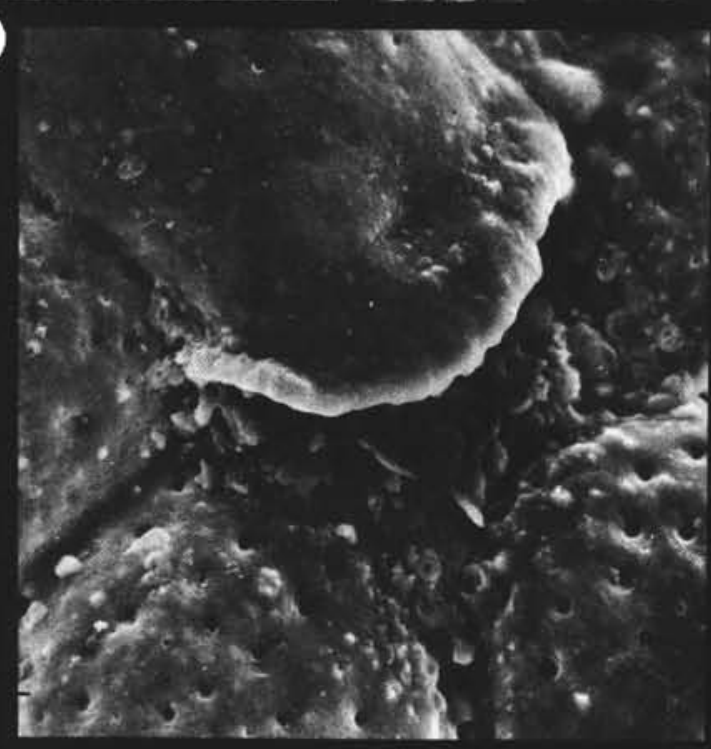

(4) 


\section{PLATE 4}

Figure 1

Figure 2

Figure 3

Figure 4
Globigerina pachyderma (Ehrenberg). Spiral view of a right coiling specimen; $\times 210$. Sample DSDP 132-1-4, 49-51 cm. Late Quaternary of the Tyrrhenian Basin.

Detail of Figure 1 showing the thick, heavily calcified chamber wall; $\times 1000$.

Globigerina pachyderma (Ehrenberg). Umbilical view; $\times 210$. Sample DSDP 132-1-4, 49-51 cm.

Detail of Figure 3 showing the narrow and deep umbilicus, the umbilical aperture extending towards the periphery and the thick calcitic prisms surrounding the umbilical area; $\times 625$. 


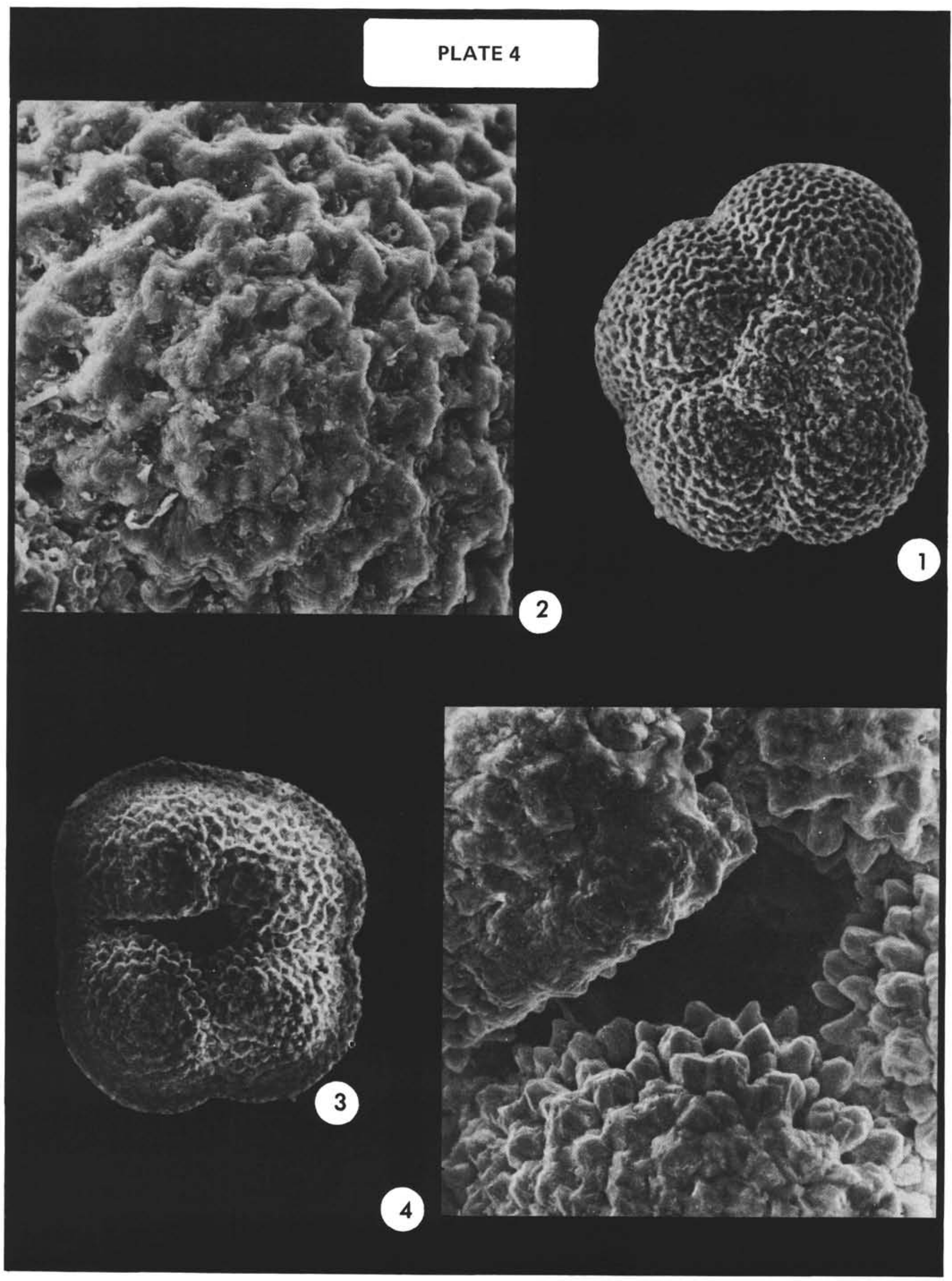


M. B. CITA, M. A. CHIERICI, G. CIAMPO, M. MONCHARMONT ZEI, S. d'ONOFRIO, W. B. F. RYAN, R. SCORZIELLO

\section{PLATE 5}

Figure 1 Globigerina bulloides d'Orbigny. Umbilical view; $\times 135$. Sample DSDP 132-1-2, 75-77 cm. Late Quaternary of the Tyrrhenian Basin.

Figure 2 Detail of Figure $2 ; \times 250$.

Figure 3 Detail of Figure 1, showing the umbilical aperture, the aperture of the penultimate chamber and the thin calcitic spines which, in the living specimens, cover the entire test: $\times 460$.

Figure $4 \quad$ Globigerinoides quadrilobatus (d'Orbigny). Umbilical view; X120. Sample DSDP 132-1-2, 75-77 cm. Late Quaternary of the Tyrrhenian Basin.

Figure 5

Detail of Figure 4; $\times 250$.

Figure 6 Detail of Figure 4, showing the wide and deep pores, cancellate surface and thin calcitic spines developed in the umbilical area; $\times 400$. 


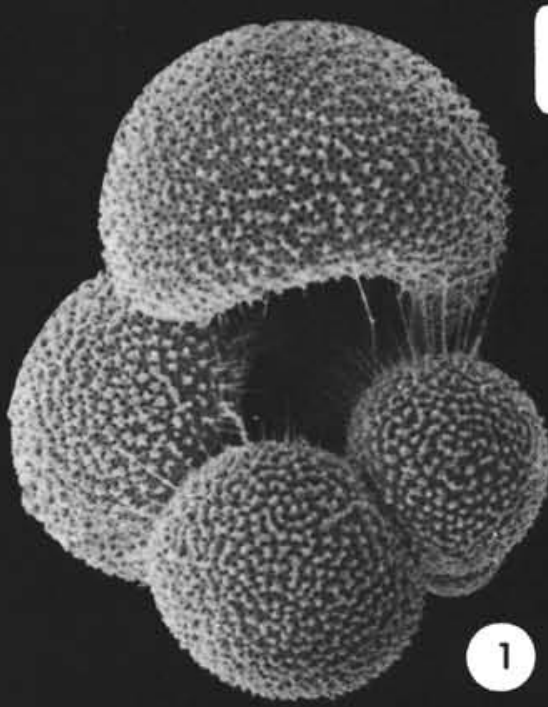

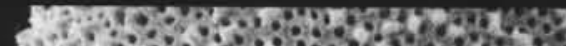
nop

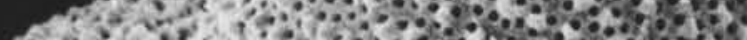
F

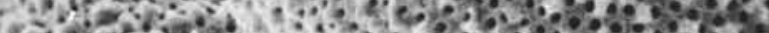

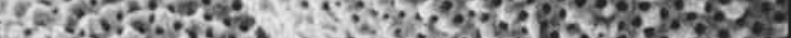

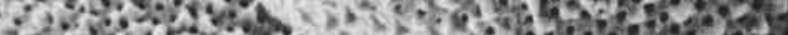

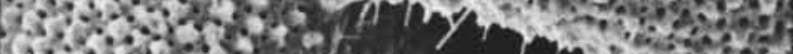

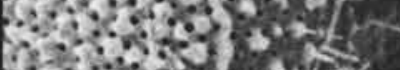

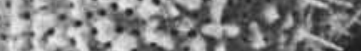
H.

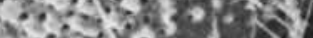

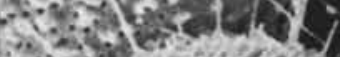

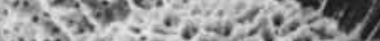

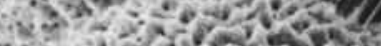

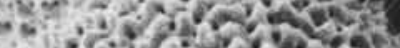

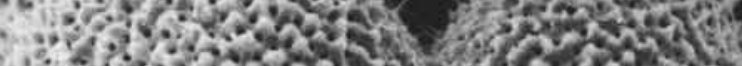

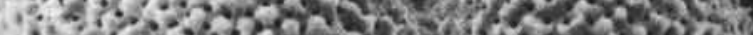

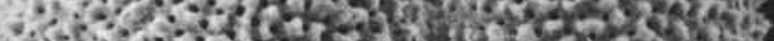

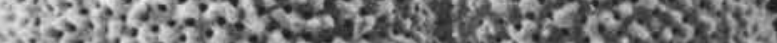

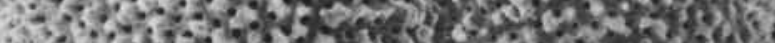

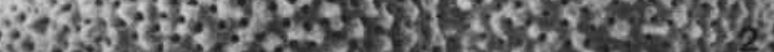

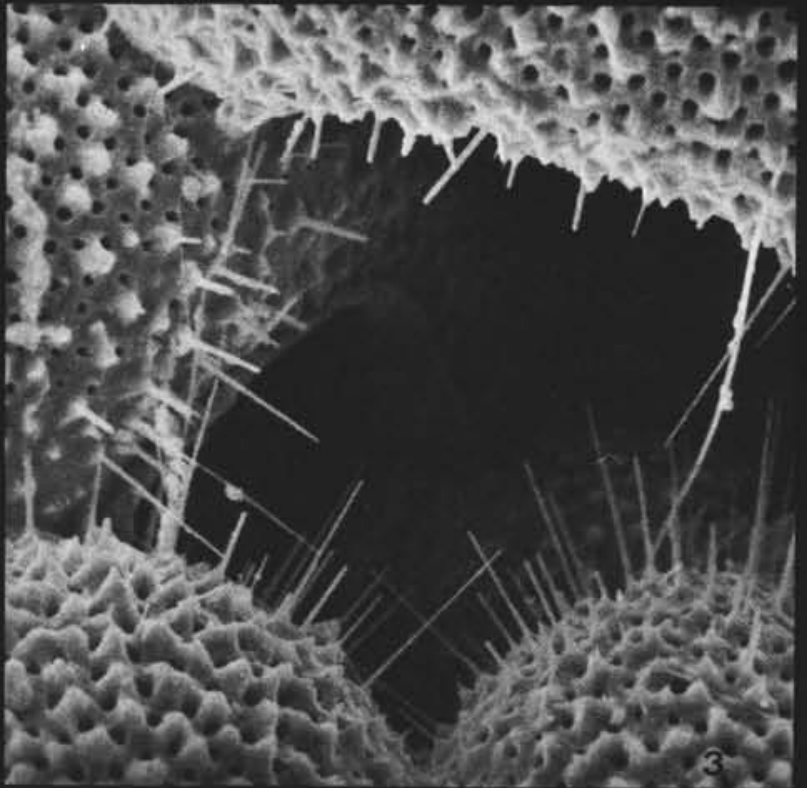

PLATE 5

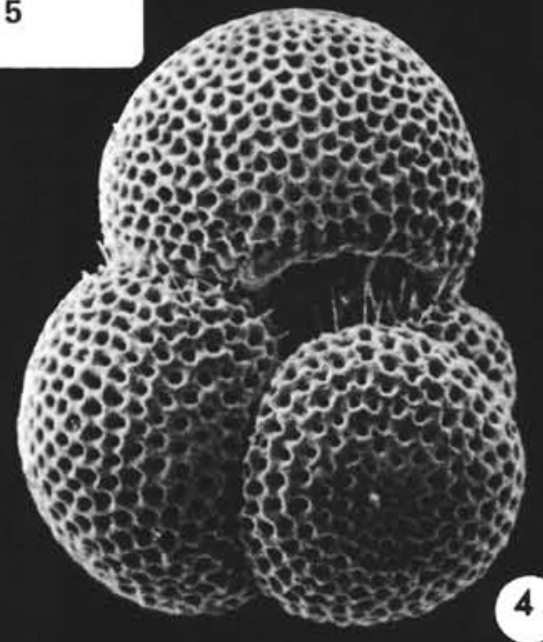

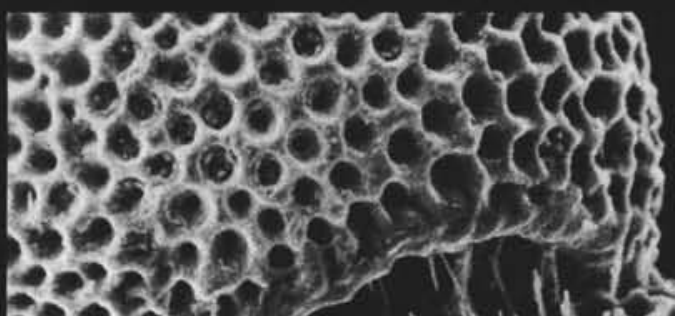

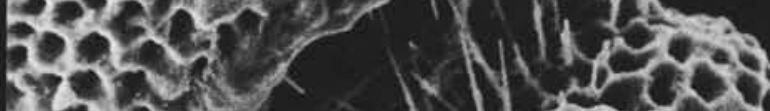

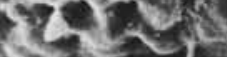

Sache

for 20 -

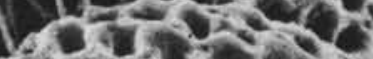

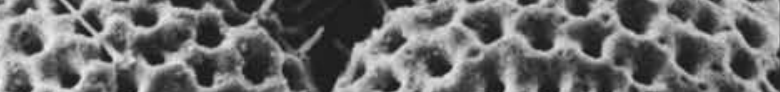

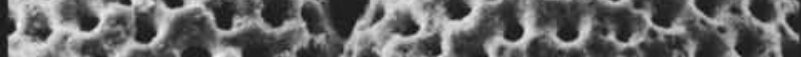
5.5.6.

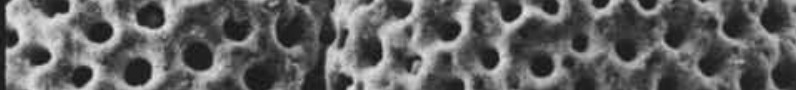

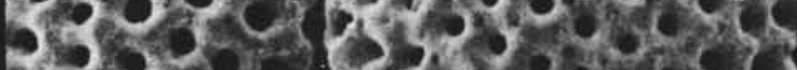

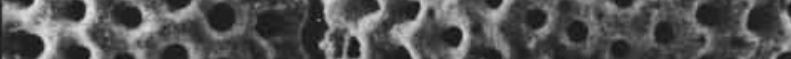

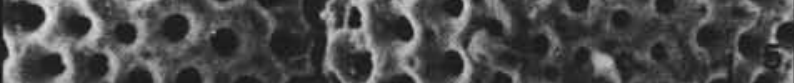

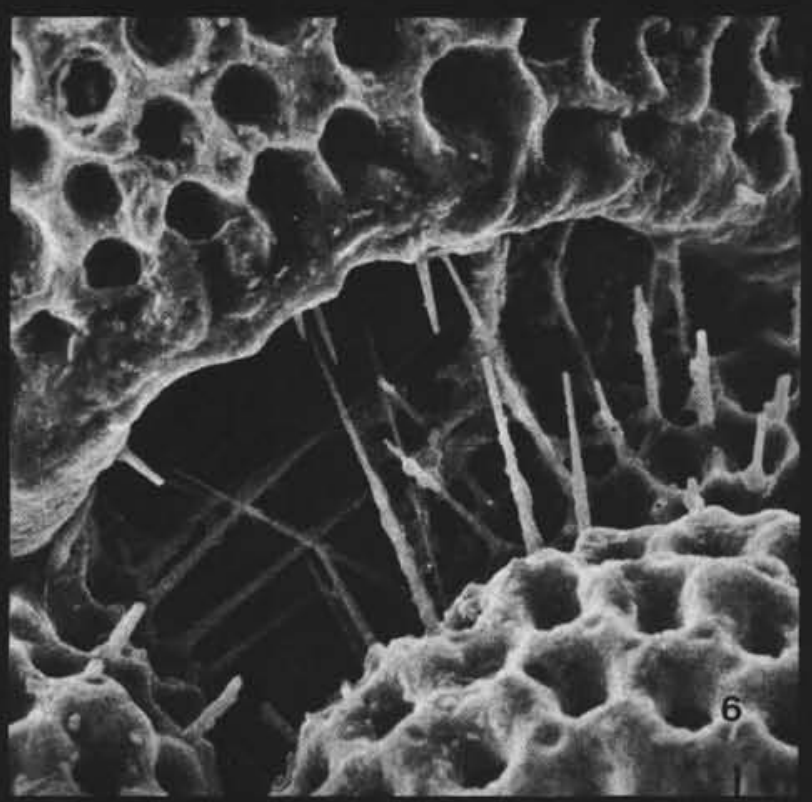




\section{PLATE 6}

Figure $1 \quad$ Globigerinoides conglobatus (Brady). Spiral view; X110. Sample DSDP 132-6-3, 124-126 cm. Lower Pleistocene of the Tyrrhenian Basin.

Figure 2 Globigerinoides conglobatus (Brady). Spiral view of a very large specimen, showing a small globigerinid fitting in one of the supplementary apertures; X85. Sample DSDP 132-6-3, 124-126 cm.

Figure 3 Globigerinoides gomitulus (Seguenza). Umbilical view; $\times 150$. Sample DSDP 132-6-3, 124-126 cm.

Figure $4 \quad$ Globigerinoides conglobatus (Brady). Umbilical view; $\mathrm{X} 110$. Sample DSDP 132-6-3, $124-126 \mathrm{~cm}$.

Figure 5 Detail of Figure 3 (Globigerinoides gomitulus) showing the primary aperture, the highly spinose surface and a number of coccoliths partly assimilated by the chamber wall; $\times 840$.

Figure 6 Detail of Figure 4 (Globigerinoides conglobatus) showing the primary aperture, the deeply depressed intercameral sutures and the heavily calcified and thickened chamber wall, $\times 250$. 


\section{Plate 6}
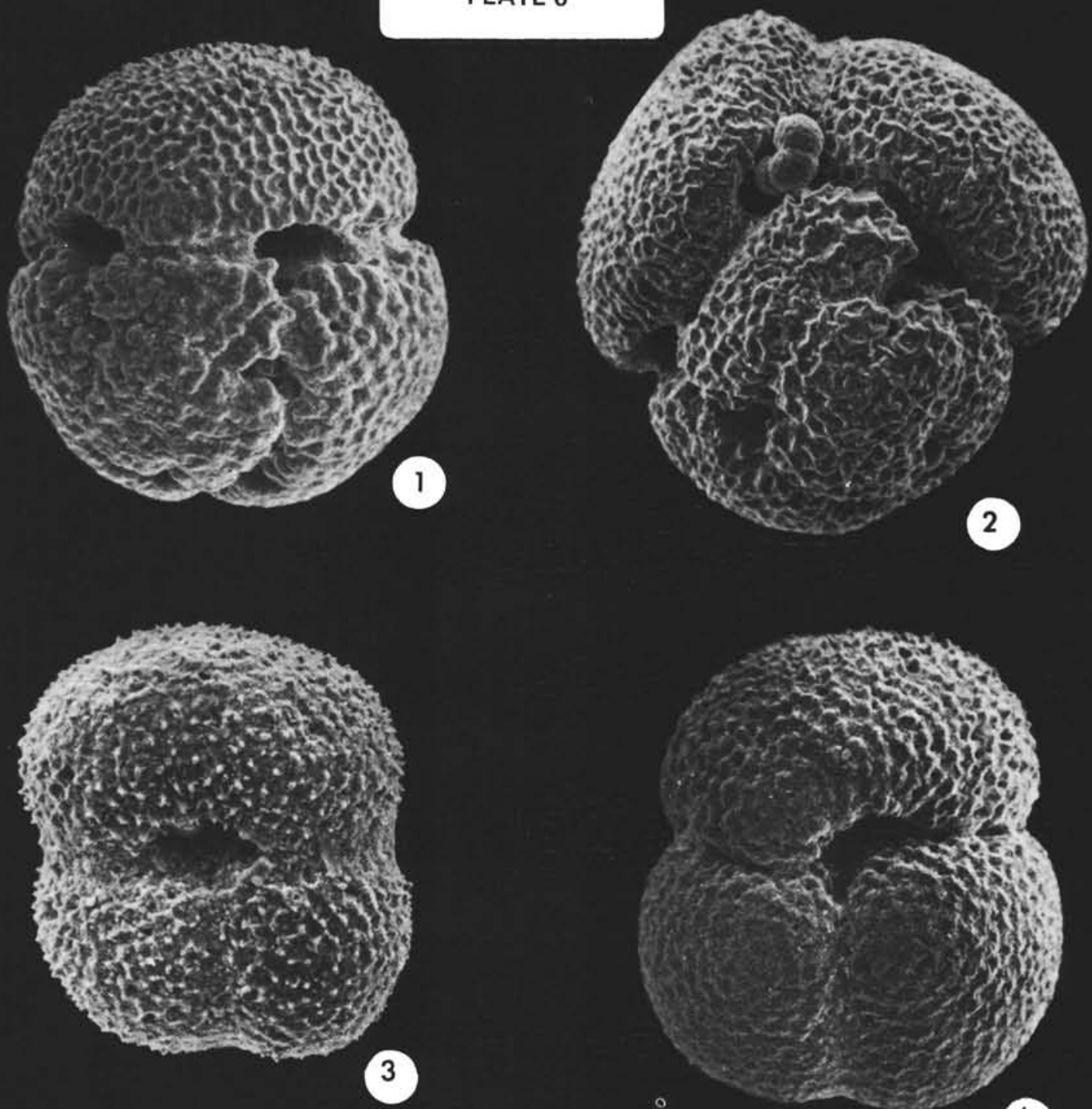

4
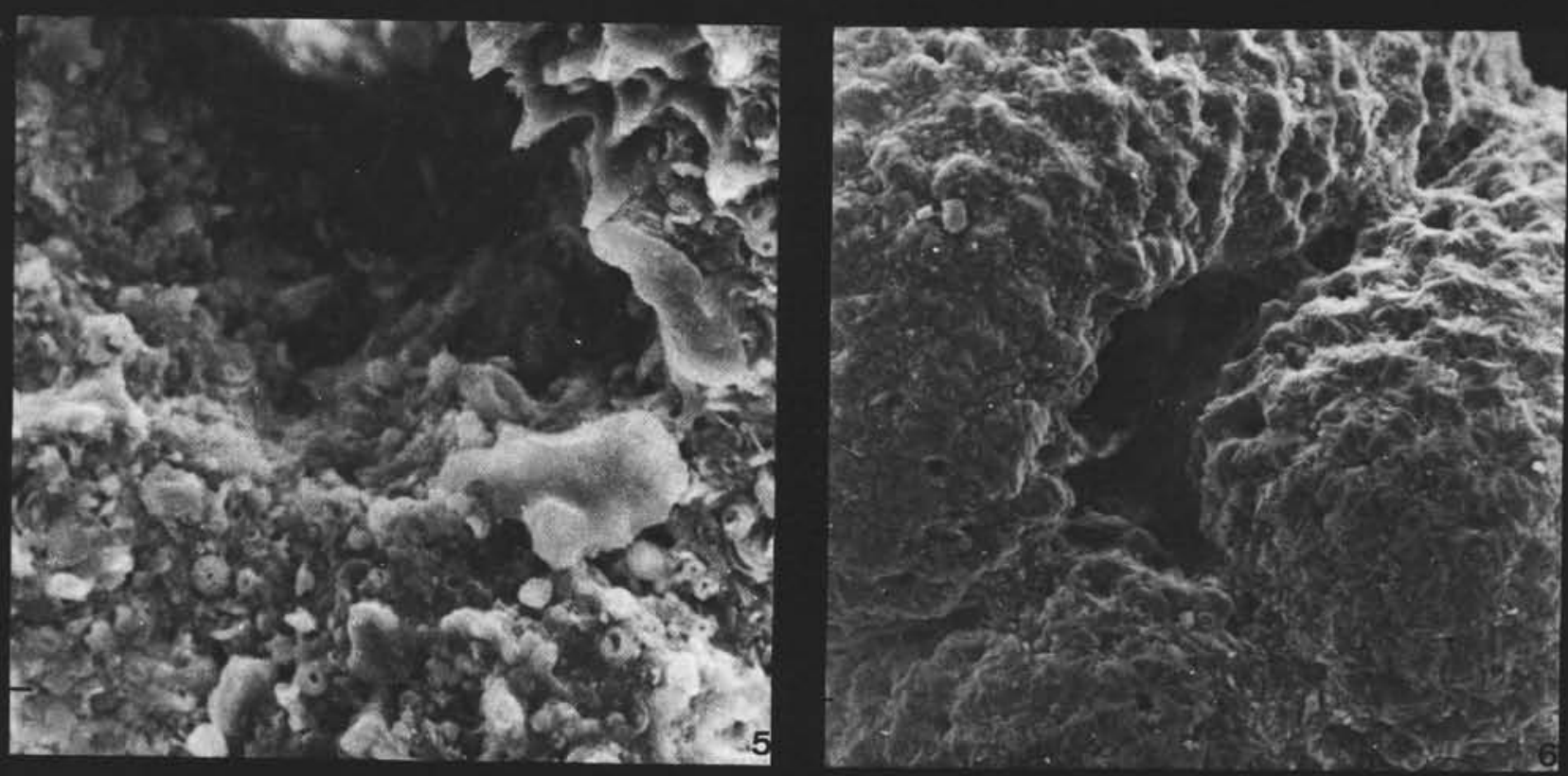


\section{PLATE 7}

Figure $1 \quad$ Globigerinoides conglobatus (Brady). Umbilical view; $\times 130$. Sample DSDP 132-6-3, 124-126 cm. Lower Pleistocene of the Tyrrhenian Basin.

Figure 2 Detail of the primary aperture of Globigerinoides conglobatus (see Figure 1) showing heavily calcified and thickened chamber wall; $\times 500$.

Figure 3 Globigerinoides ruber (d'Orbigny). Umbilical view; $\times 150$. Sample DSDP 132-1-2, 75-77 cm. Quaternary of the Tyrrhenian Basin.

Figure $4 \quad$ Globigerinoides sacculifer (Brady). Spiral view; $\times 120$. Sample DSDP 132-1-2, 75-77 cm. Late Quaternary of the Tyrrhenian Basin.

Figure 5 Detail of Figure 4 showing the cancellate surface and three out of the four supplementary apertures; $\times 300$. 


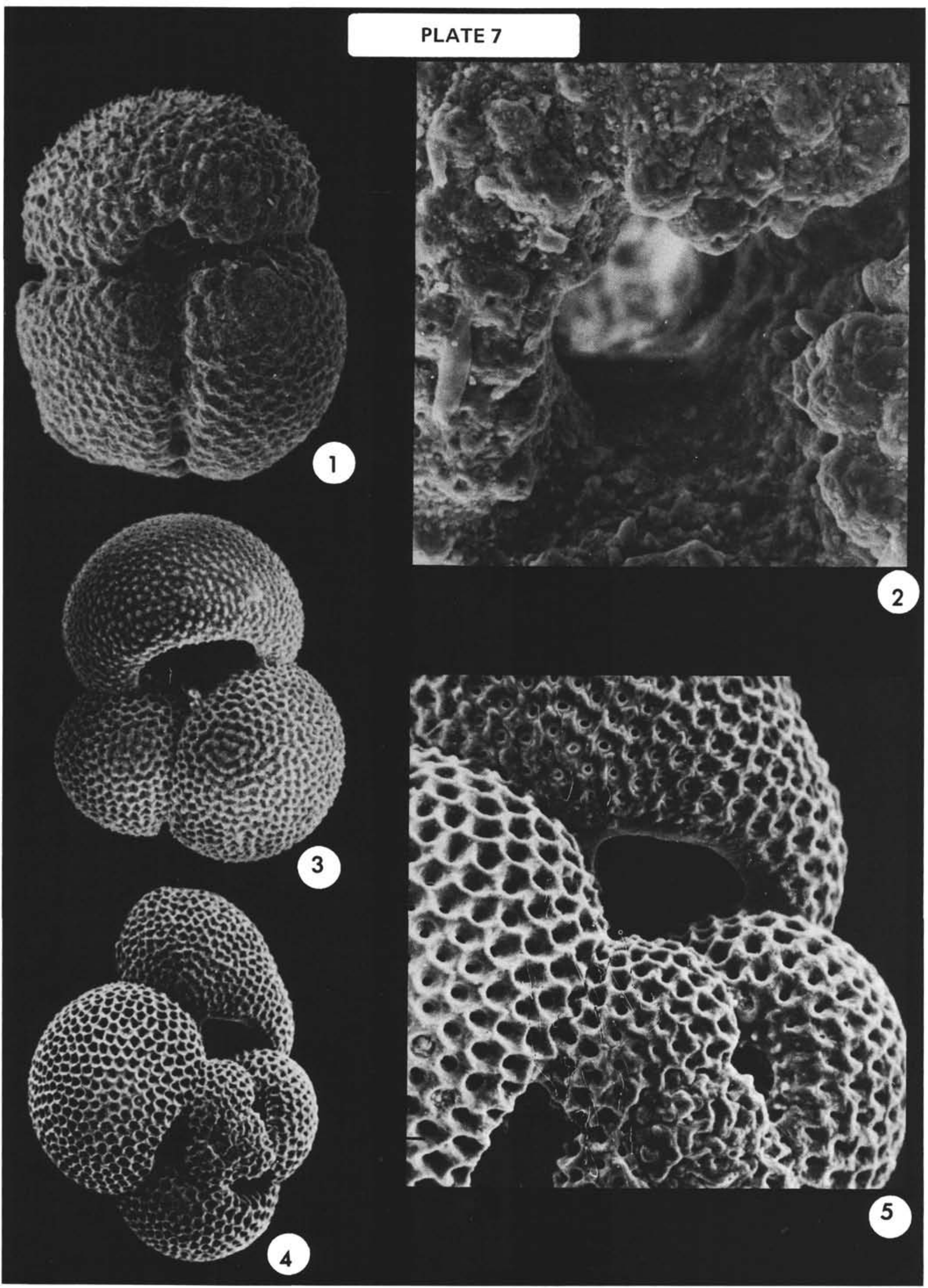


PLATE 8

Figure $1 \quad$ Globigerinoides ruber (d'Orbigny). Spiral view; $\times 110$. Sample DSDP 132-1-2, 75-77 cm. Quaternary of the Tyrrhenian basin.

Figure 2 Globigerinoides ruber (d'Orbigny). Umbilical view; $\times 120$. Sample DSDP 132. Quaternary of the Tyrrhenian basin.

Figure 3 Detail of Figure 1, showing the supplementary apertures and the structure of the wall of the early chambers; $\times 240$.

Figure 4 Detail of Figure 2, showing the umbilical aperture; $\times 400$.

Figure 5 Detail of Figure 2, showing the structure of the wall of the penultimate chamber; $\times 760$.

Figure 6 Detail of Figure 5, here magnified; $\times 2400$. 


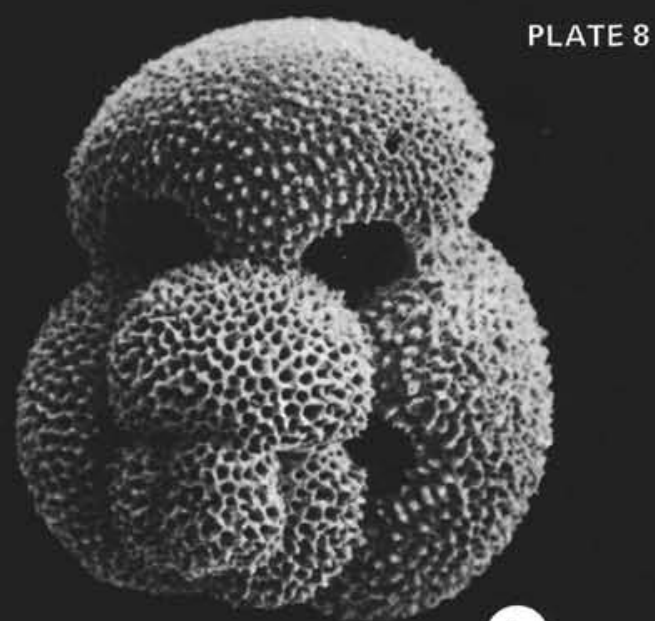

(1)

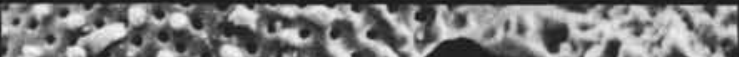

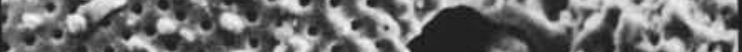

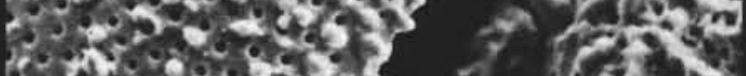

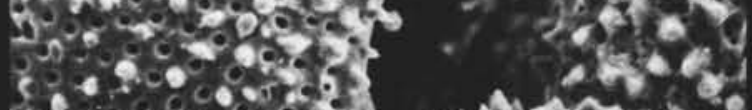

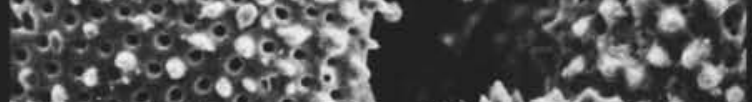

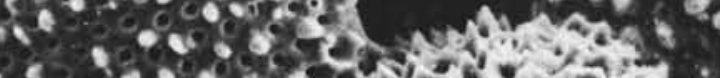

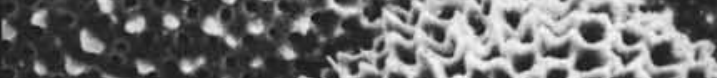

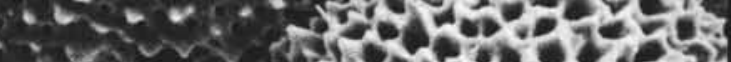

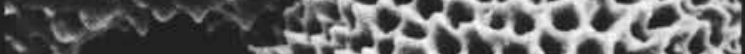

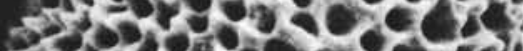

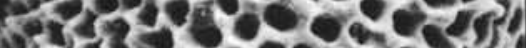

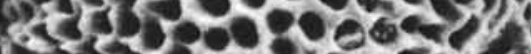
- 15320 bese

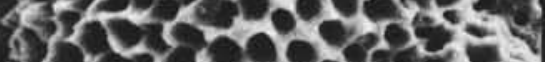
$203 x_{2}+4020$

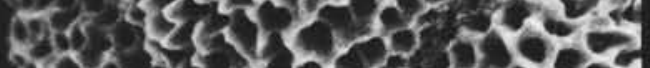

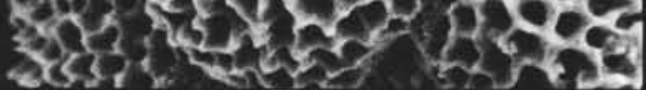

3

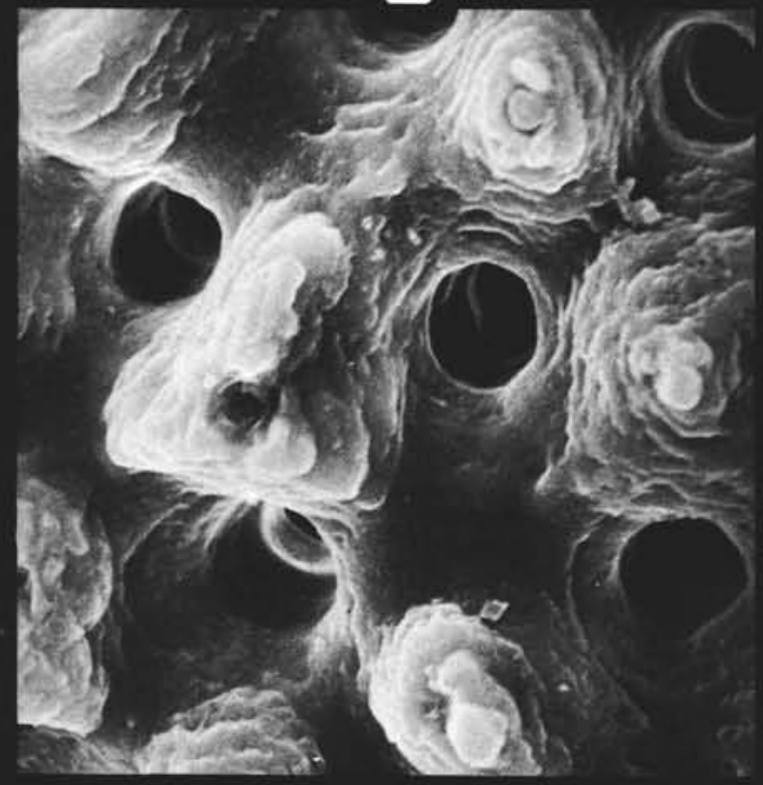

6

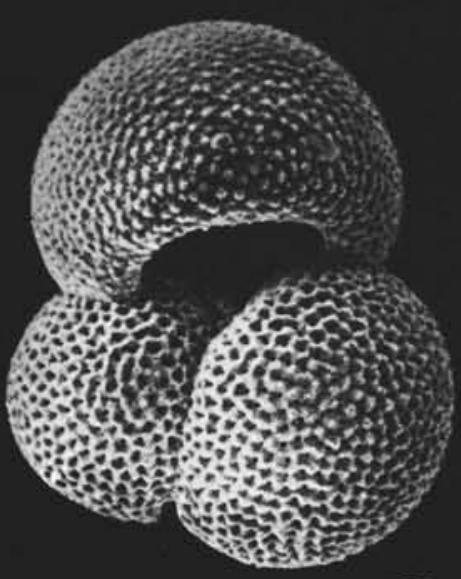

(2)

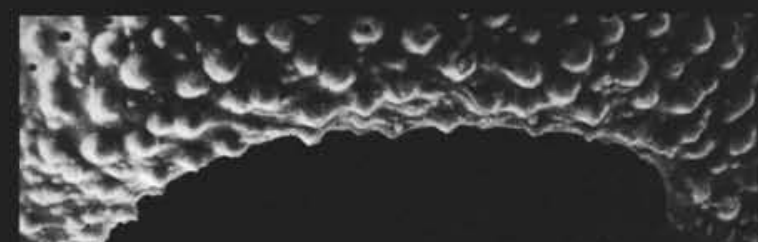

seis $x$

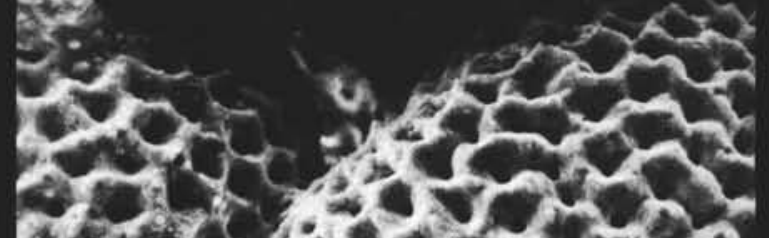

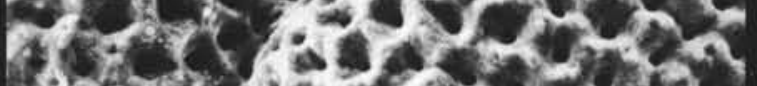
R. R. Ci.

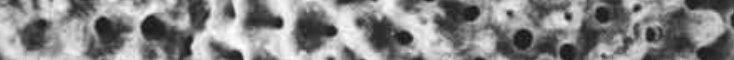

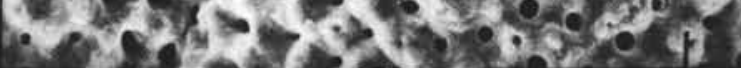

\section{4}

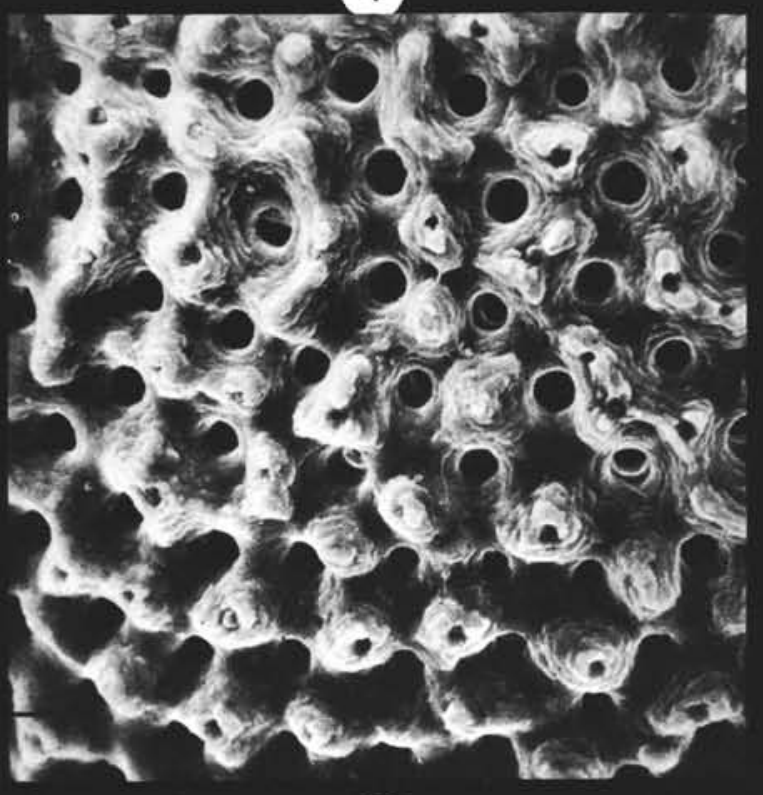

(5) 
M. B. CITA, M. A. CHIERICI, G. CIAMPO, M. MONCHARMONT ZEI,

S. d'ONOFRIO, W. B. F. RYAN, R. SCORZIELLO

PLATE 9

Figure $1 \quad$ Globigerinoides trilobus (Reuss). Umbilical view; $\times 125$. Sample DSDP $132-6-3,86-88 \mathrm{~cm}$. Lower Pleistocene of the Tyrrhenian Basin.

Figure 2 Globigerinoides helicinus (d'Orbigny). Spiral view; $\times 120$. Sample DSDP $132-6-3,86-88 \mathrm{~cm}$. Lower Pleistocene of the Tyrrhenian Basin.

Figure 3 Detail of Figure 1 showing the depressed intercameral sutures and primary aperture, $\times 385$.

Figure 4 Detail of Figure 2 showing the highly spinose surface; X1090.

Figure 5 Detail of Figure 1 showing the cancellate surface of the last chamber. A number of coccoliths are visible on the chamber wall, also obliterating the pores; X1345.

Figure 6 Detail of Figure 2 showing a supplementary aperture of the accessory chamber, in which a foreign body is present; $\times 840$. 

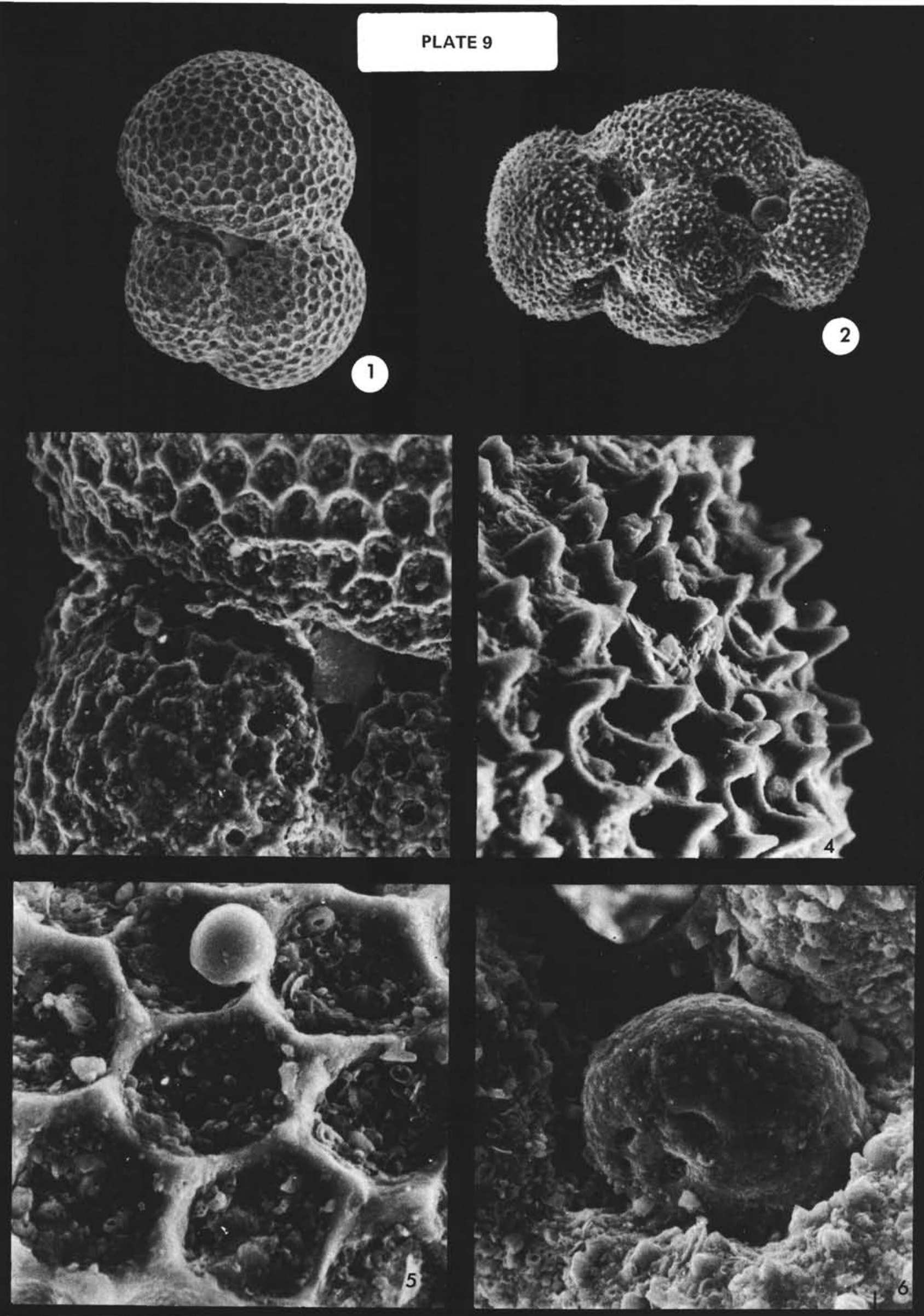
Figure $1 \quad$ Globorotalia inflata (d'Orbigny). Spiral view; $\times 105$. Sample DSDP 132-3-3, 114-116 cm. Quaternary of the Tyrrhenian basin.

Figure 2 Globorotalia inflata (d'Orbigny). Umbilical view; $\times 120$. Sample DSDP 132-3-3, 114-116. Quaternary of the Tyrrhenian basin.

Figure 3 Globorotalia inflata (d'Orbigny). Detail of Figure 1, showing the final chamber; $\times 320$.

Figure 4 Detail of Figure 2, showing the umbilical - extraumbilical aperture, $\times 240$.

Figure 5 Detail of Figure 1, showing the surface of the inner whorls, with large pores; $\times 370$.

Figure 6 Detail of Figure 2, showing the knobs of last-formed chamber, $\times 800$. 


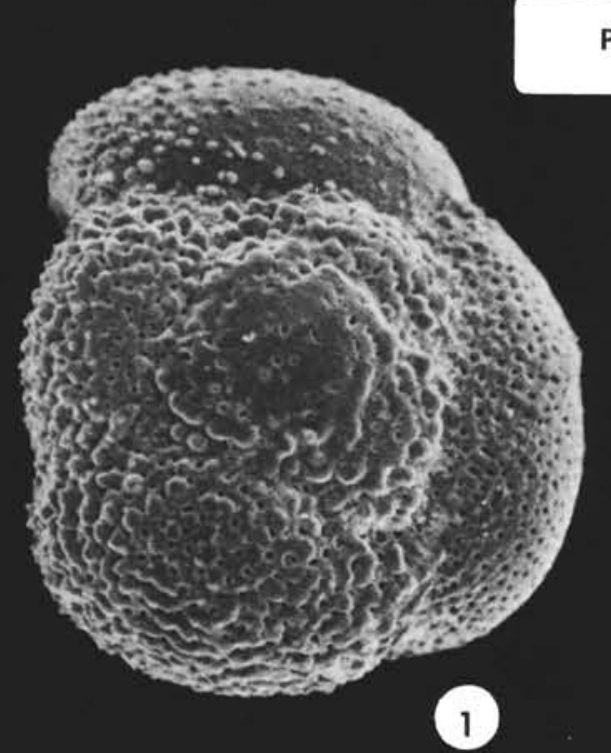

\section{PLATE 10}
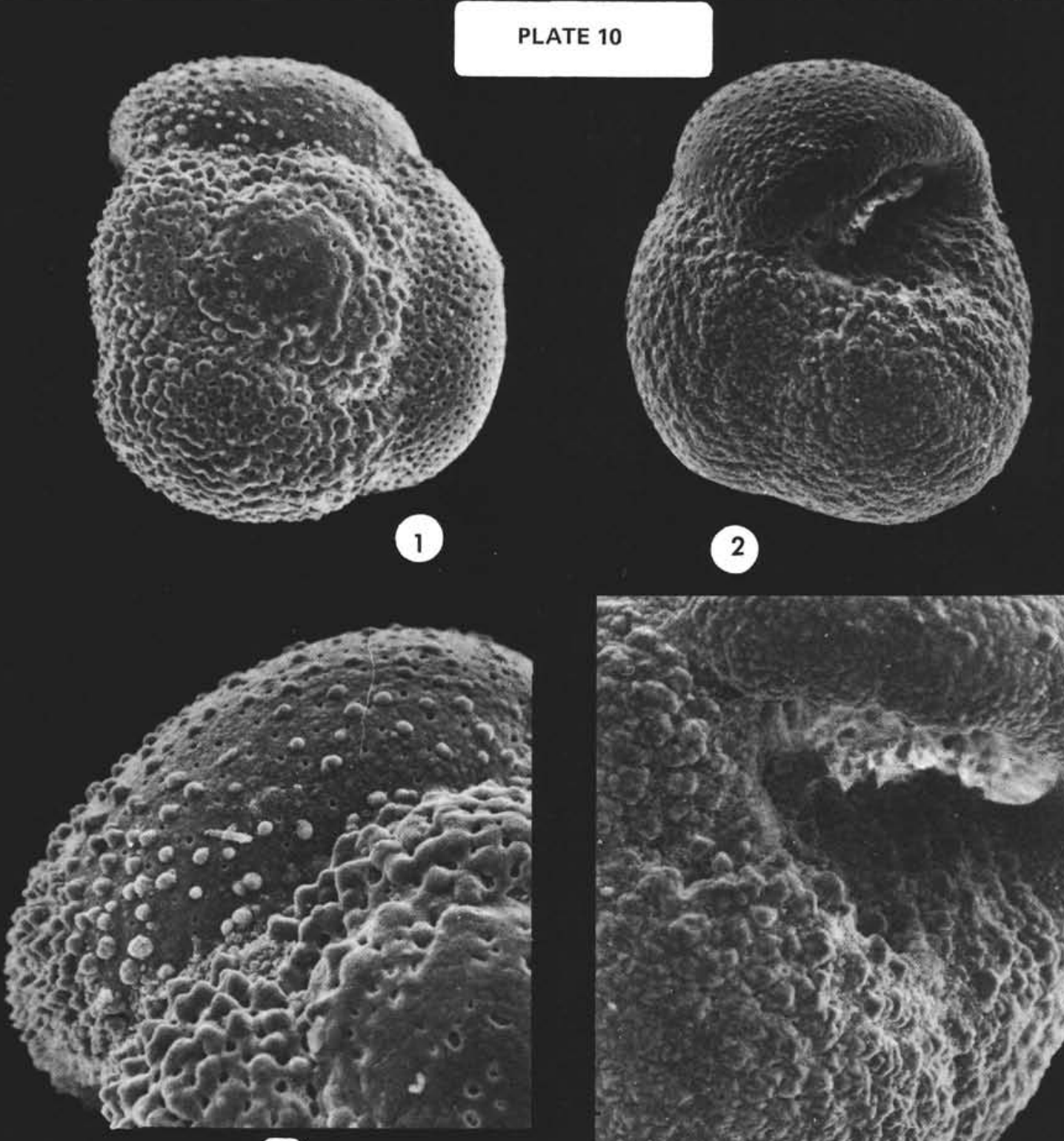

(3)
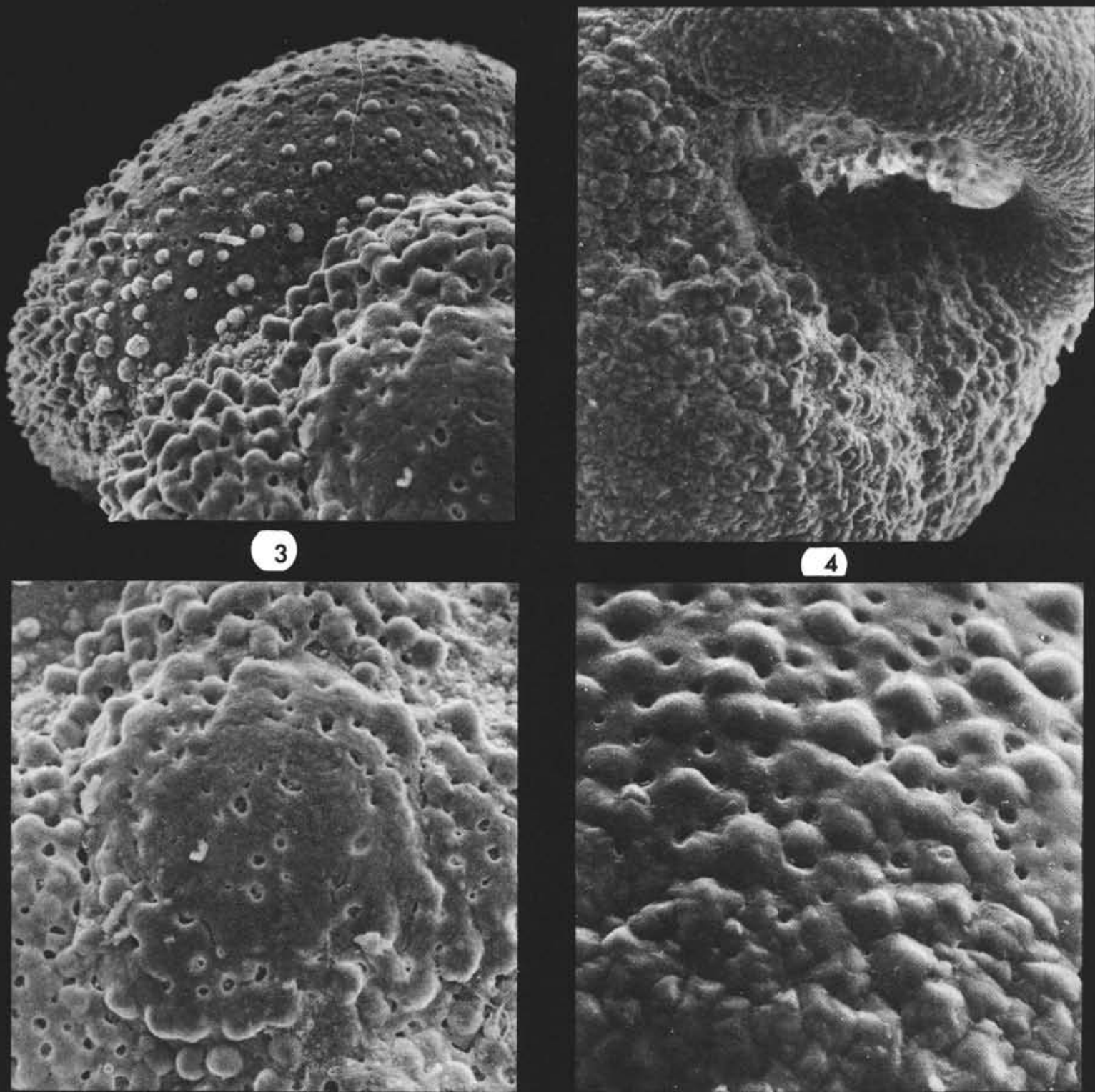

5

6 
M. B. CITA, M. A. CHIERICI, G. CIAMPO, M. MONCHARMONT ZEI,

S. d'ONOFRIO, W. B. F. RYAN, R. SCORZIELLO

\section{PLATE 11}

Figure $1 \quad$ Globorotalia inflata (d'Orbigny). Spiral view; $\times 115$. Sample DSDP 132-3-3, 114-116 cm. Quaternary of the Tyrrhenian basin.

Figure 2 Detail of Figure 1, showing the smooth wall of the last formed chamber; $\times 385$.

Figure 3 Globorotalia inflata (d'Orbigny). Apertural view; $\times 115$. Sample DSDP $132-3-3,114-116 \mathrm{~cm}$. Quaternary of the Tyrrhenian basin.

Figure 4 Detail of Figure 3 , showing the umbilicalextraumbilical aperture; $\times 230$.

Figure 5 Detail of Figure 1, showing the smooth wall and the small pores of the last-formed chamber; $\times 2310$. 

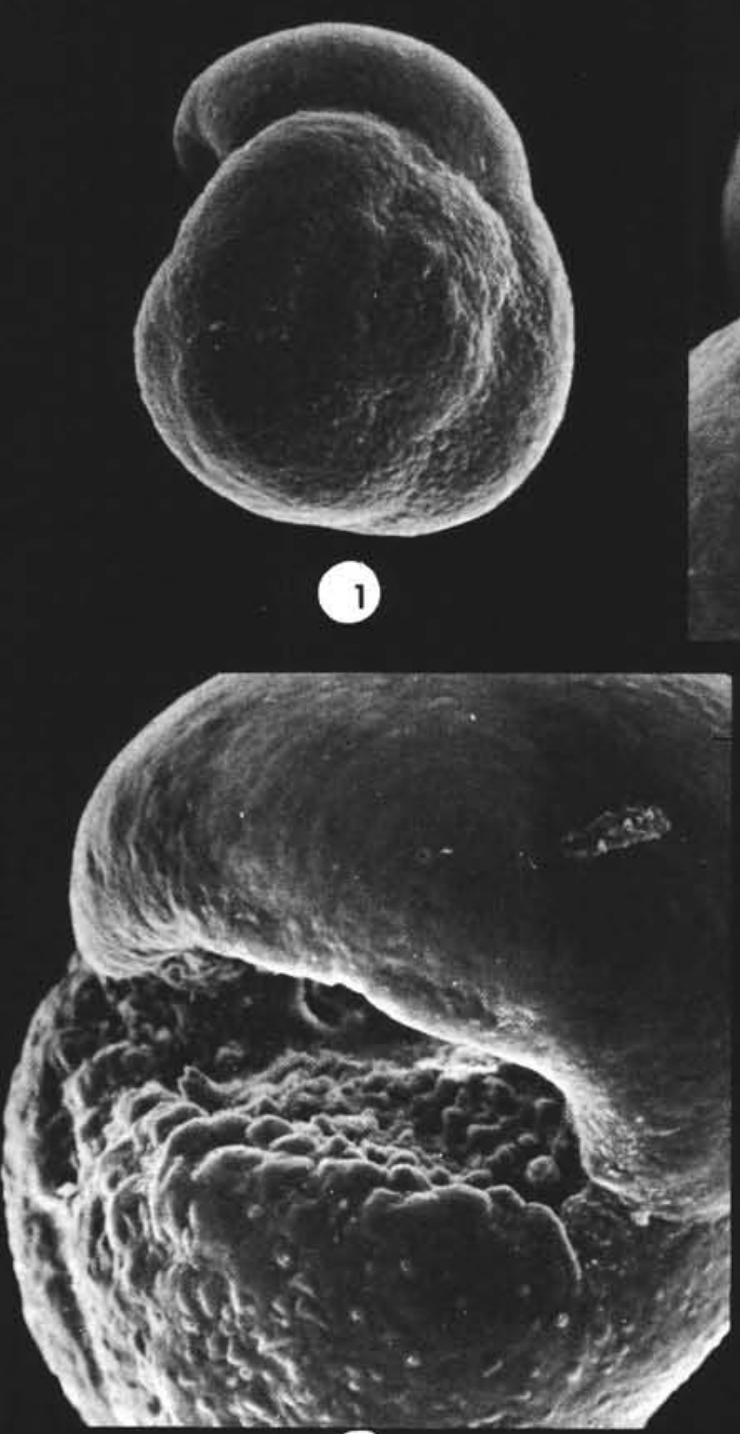

(4)
0

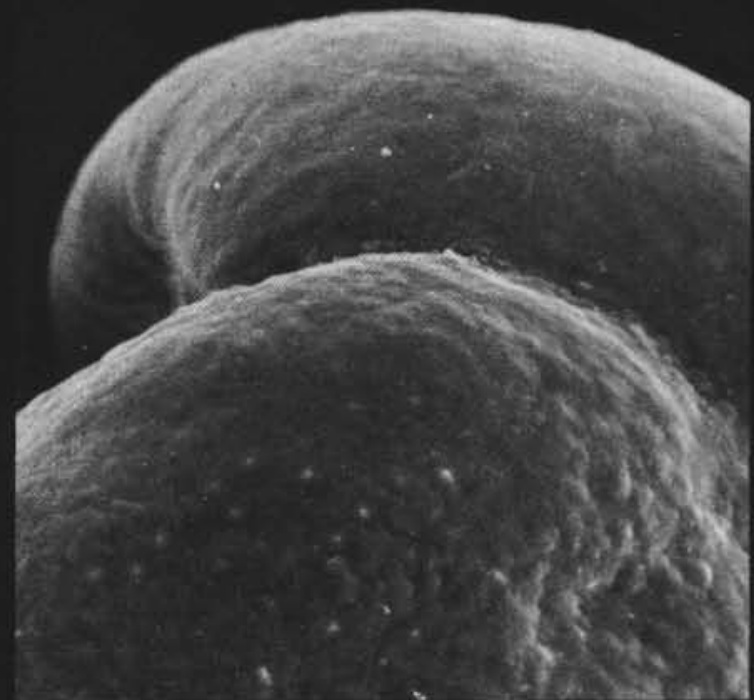

2

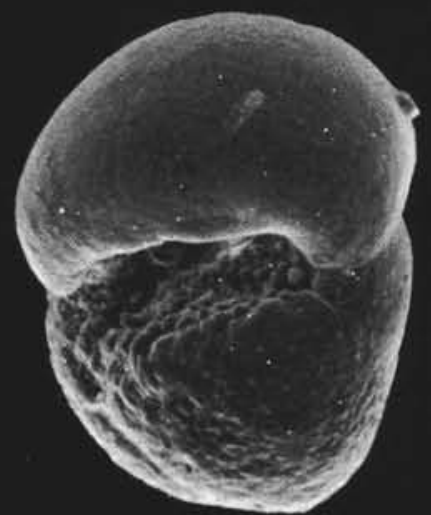

(3)

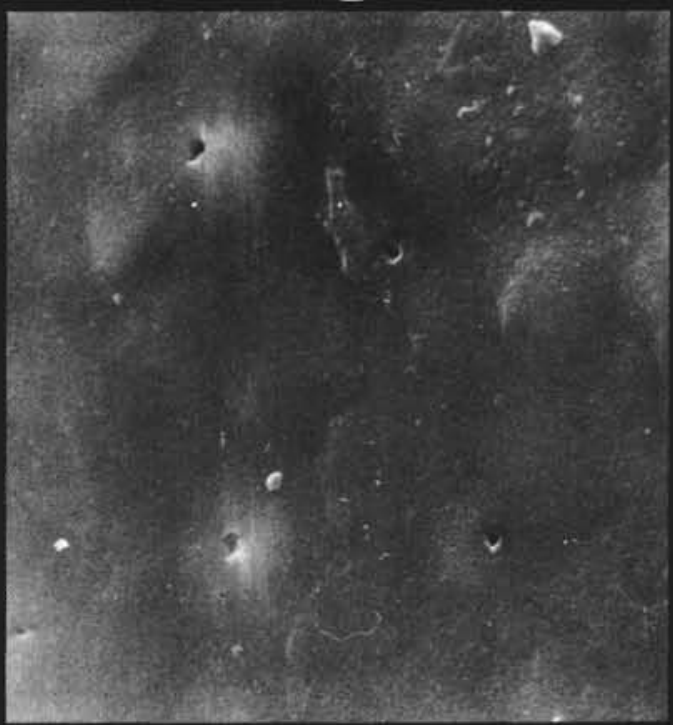

5 
Figure 1 Globorotalia crassaformis (Galloway \& Wissler). Spiral view; $X 110$. Sample DSDP 132-6-3, 86-88 cm. Lower Pleistocene of the Tyrrhenian Basin.

Figure 2 Globorotalia crassaformis (Galloway \& Wissler). Umbilical view; $\times 110$. Sample DSDP 132-6-3, $124-126 \mathrm{~cm}$. Lower Pleistocene of the Tyrrhenian Basin.

Figure 3 Detail of Figure 2, showing the umbilicalextraumbilical aperture with a distinct lip. The final chamber is distinctly smaller than the penultimate, and less pitted; $\times 320$.

Figure 4 Globorotalia crassaformis (Galloway \& Wissler). Umbilical view; X130. Sample DSDP 132-6-3, 86-88 $\mathrm{cm}$. Lower Pleistocene of the Tyrrhenian Basin.

Figure 5. Detail of Figure 4, showing the finely perforate last-formed chamber; $\times 435$. 


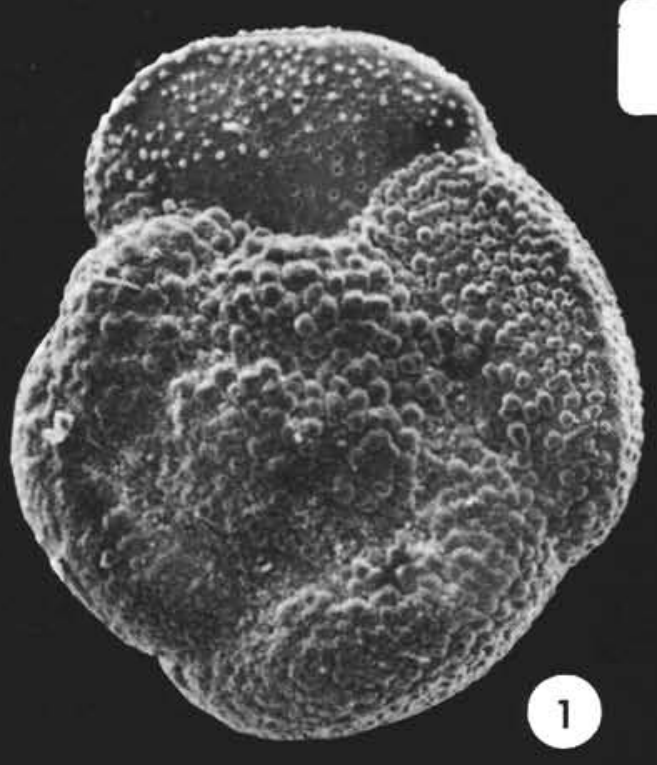

PLATE 12
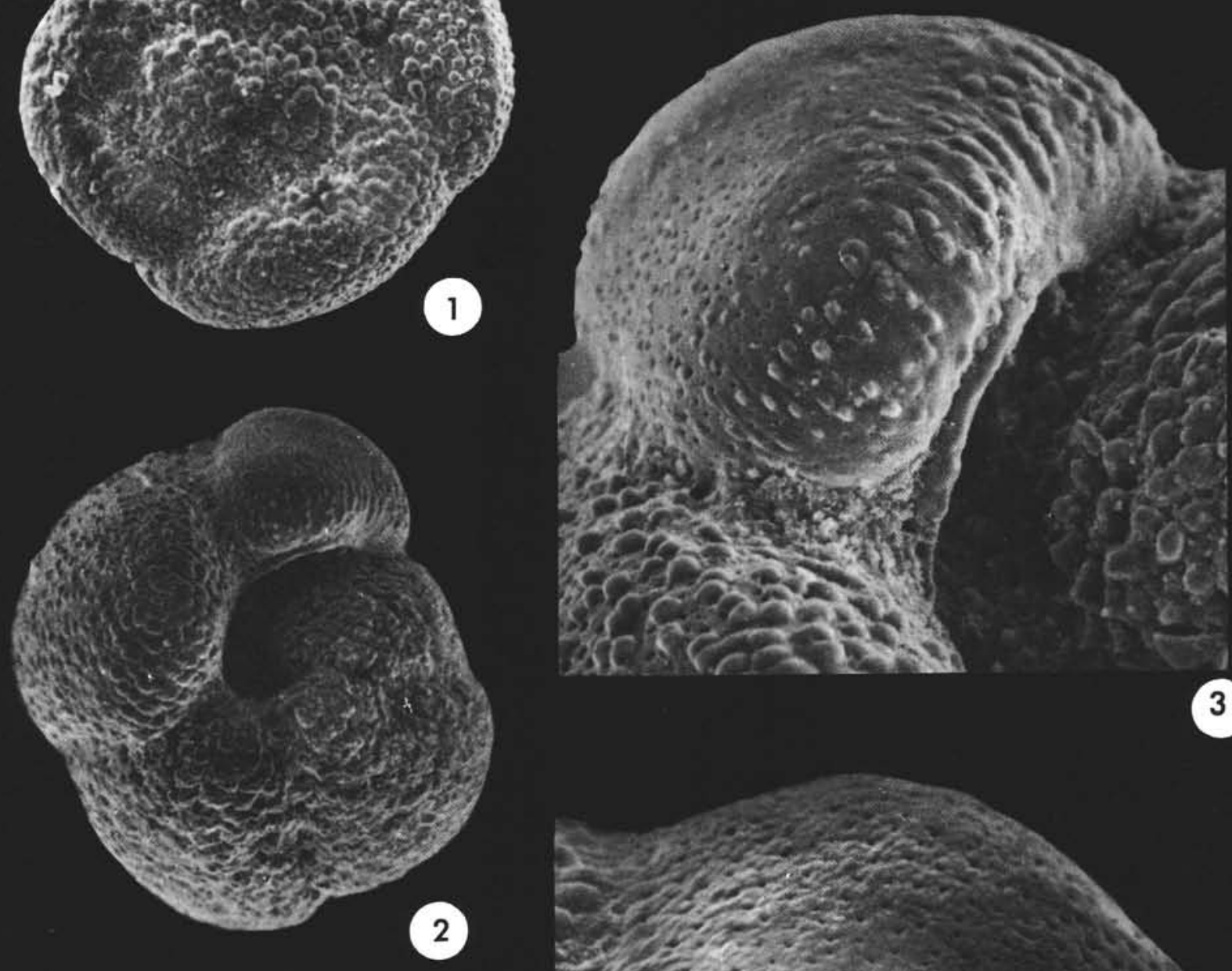

3
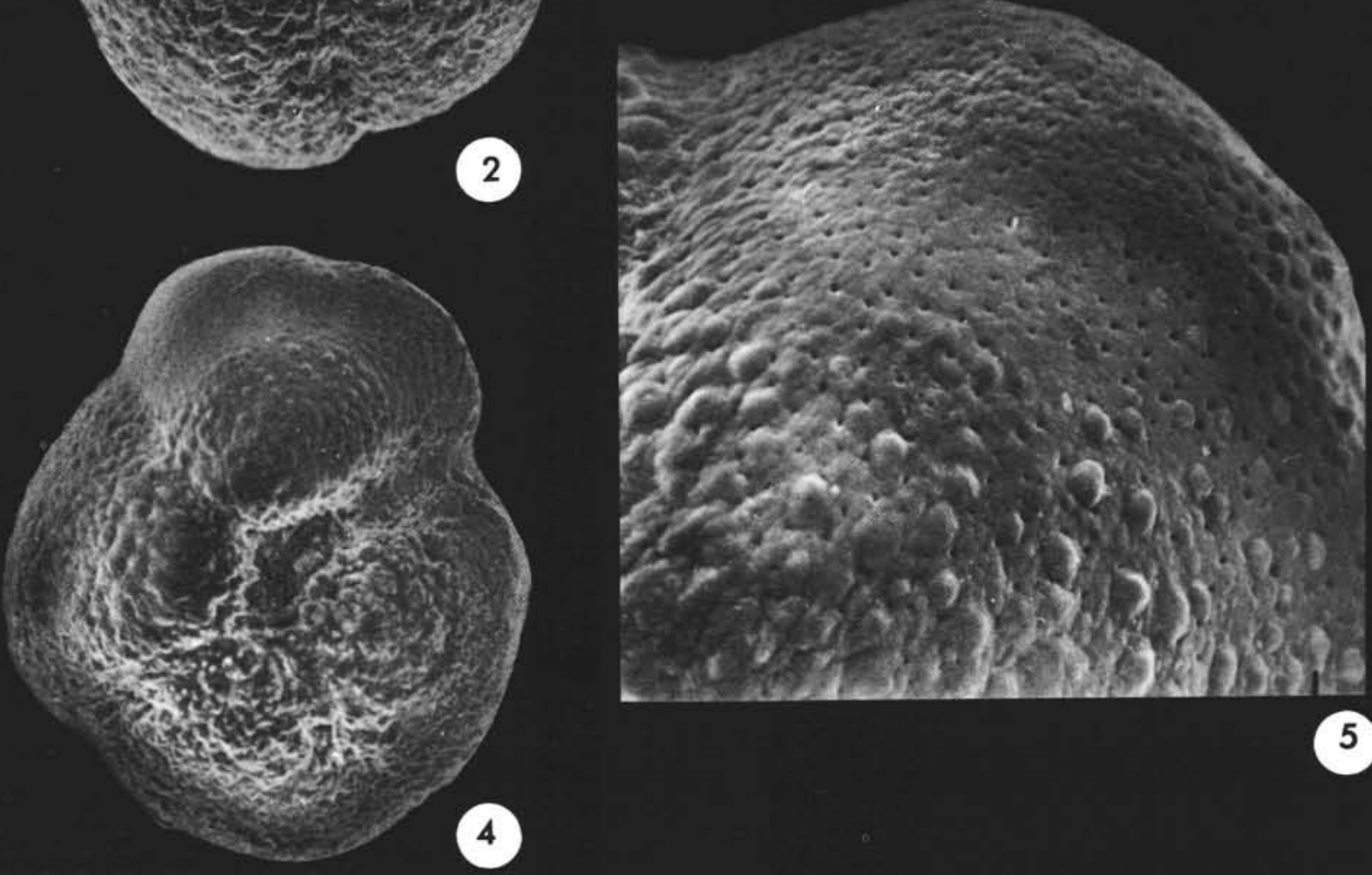

(5) 
M. B. CITA, M. A. CHIERICI, G. CIAMPO, M. MONCHAR MONT ZEI, S. d'ONOFRIO, W. B. F. RYAN, R. SCORZIELLO

\section{PLATE 13}

Figure $1 \quad$ Globorotalia scitula (Brady). Spiral view; $\times 170$. Sample DSDP $132-1-4,49-51 \mathrm{~cm}$. Quaternary of the Tyrrhenian Basin.

Figure $2 \quad$ Globorotalia scitula (Brady). Umbilical view; $\times 170$. Sample DSDP 132-1-4, 49-51 cm.

Figure 3 Detail of Figure 1 showing the depressed intercameral sutures and the surface of the inner whorls, with large pores; $\times 395$.

Figure 4 Detail of Figure 2 showing the umbilicalextraumbilical interiomarginal aperture with an umbilical expansion. Also visible are the depressed intercameral sutures and numerous knobs surrounding the umbilical depression; $\times 475$.

Figure 5 Detail of Figure 3 showing the thickened wall and deep pores of the early chambers (see arrow in Figure 4 indicating the area here magnified) $\times 3955$. 


\section{PLATE 13}
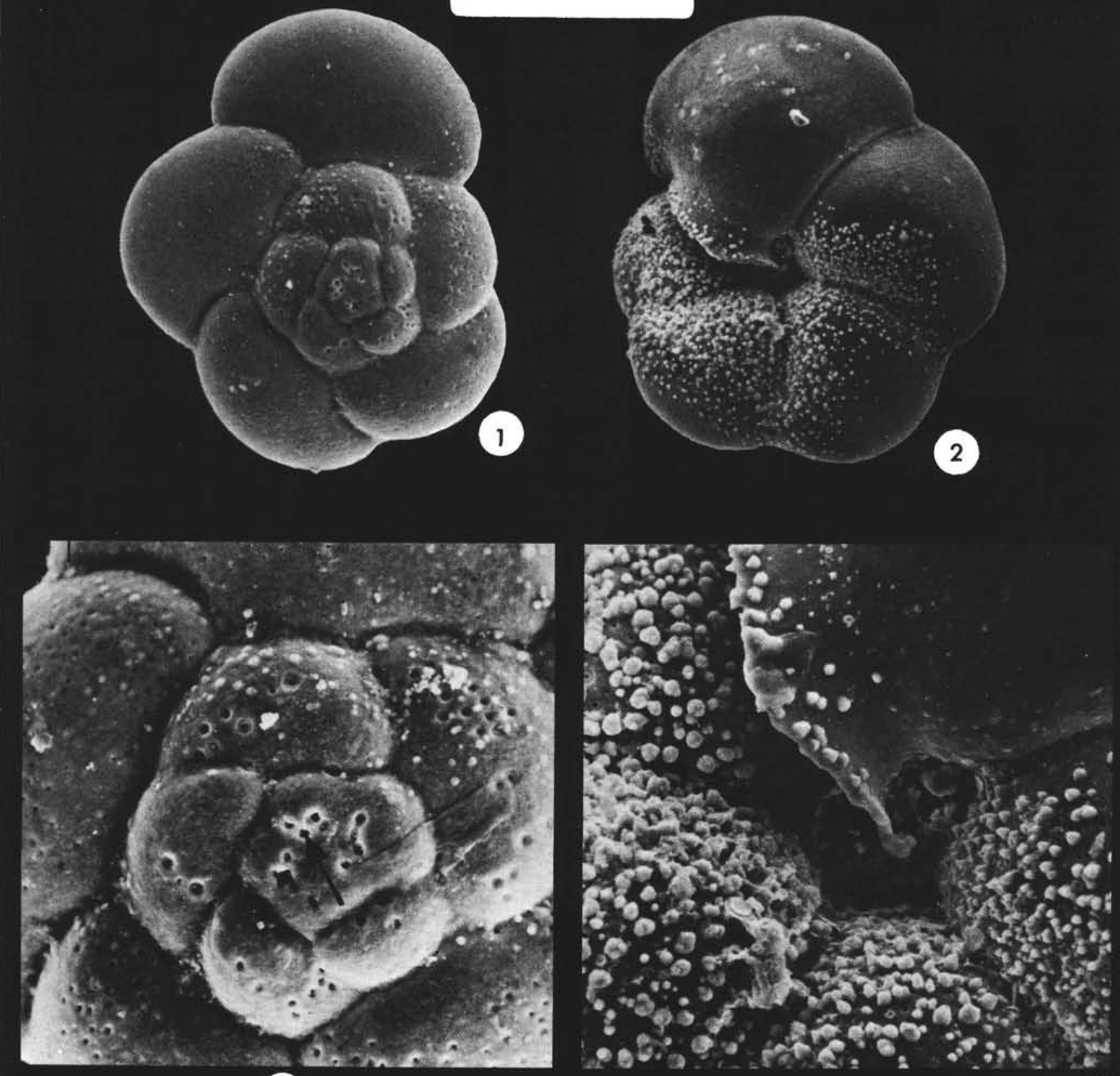

(3)

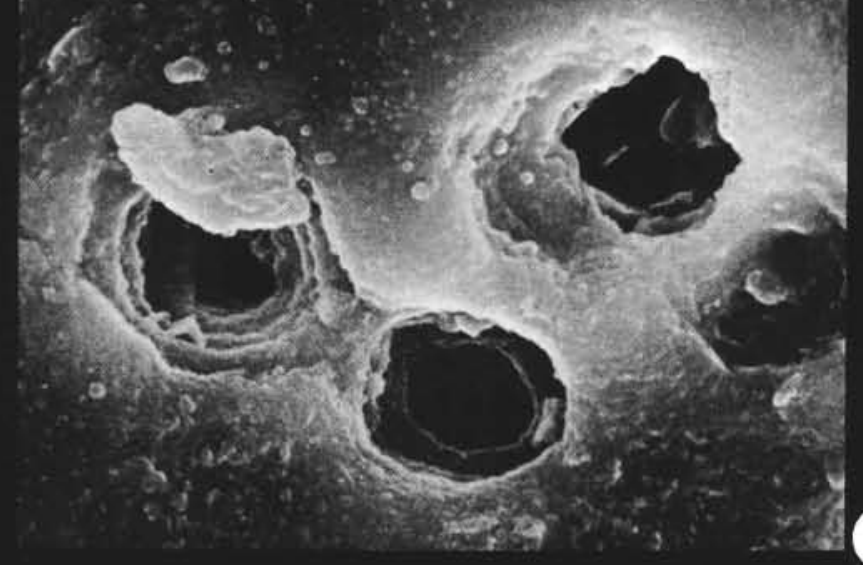


PLATE 14

Figure 1

Figure 2

Figure 3

Figure 4

Figure 5

Figure 6
Globorotalia scitula (Brady). Var. Umbilical view; $\times 155$. Sample 132-6-3, 124-126 cm. Quaternary of the Tyrrhenian Basin.

Detail of Figure 1, showing the umbilicalextraumbilical aperture and the apertural lip; $\times 425$.

Detail of Figure 1, showing the distribution of the pores on the penultimate chamber; $\times 770$.

Detail of Figure 1, showing knobs and pores in the aperture; $\times 770$.

Detail of Figure 3, showing the thickened wall and comparatively small pores; $\times 2310$.

Detail of Figure 1, showing the suture between the penultimate and ultimate chambers; $\times 770$. 


\section{PLATE 14}
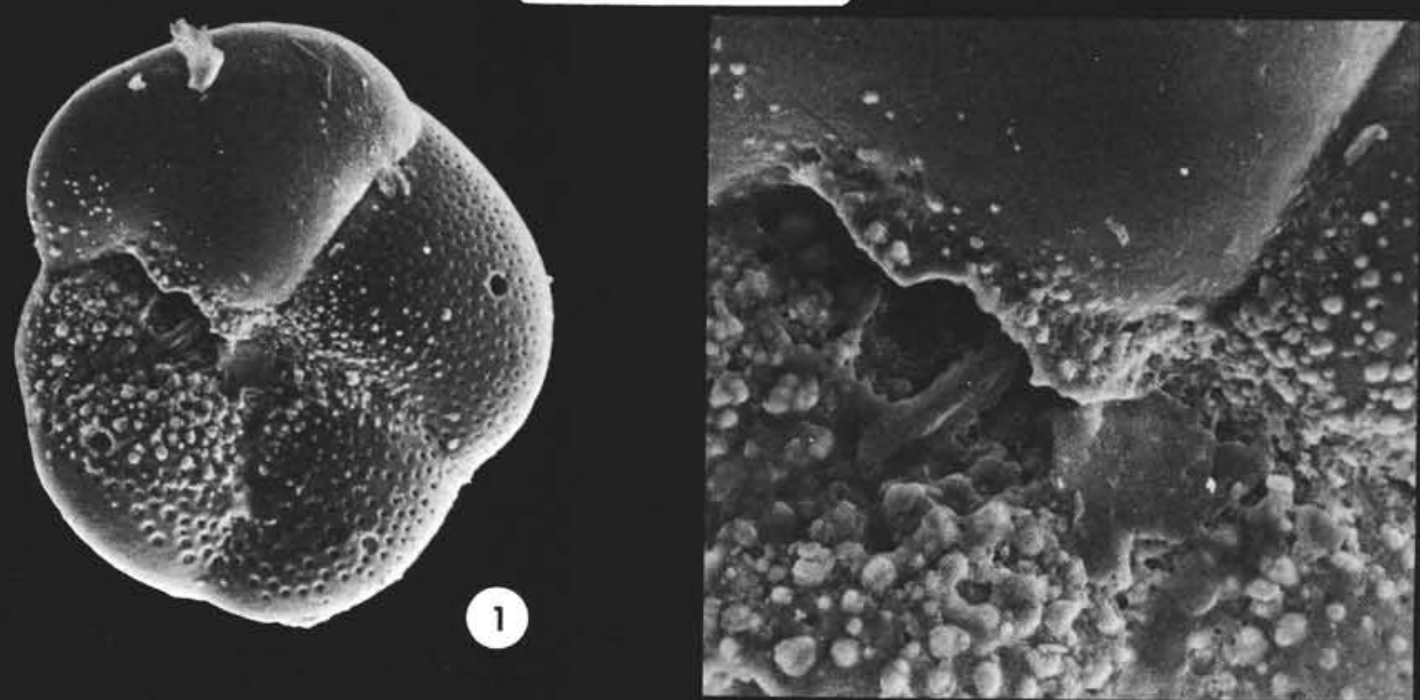

(2)

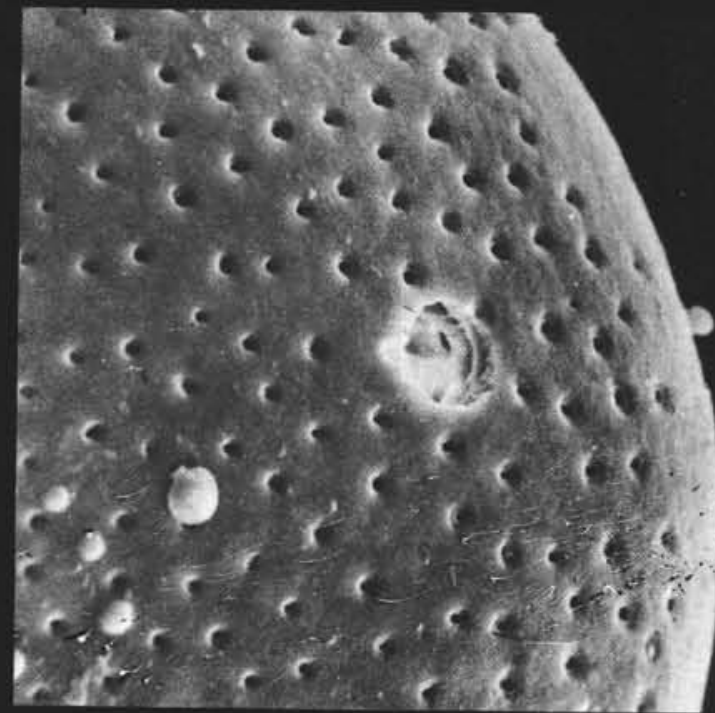

3

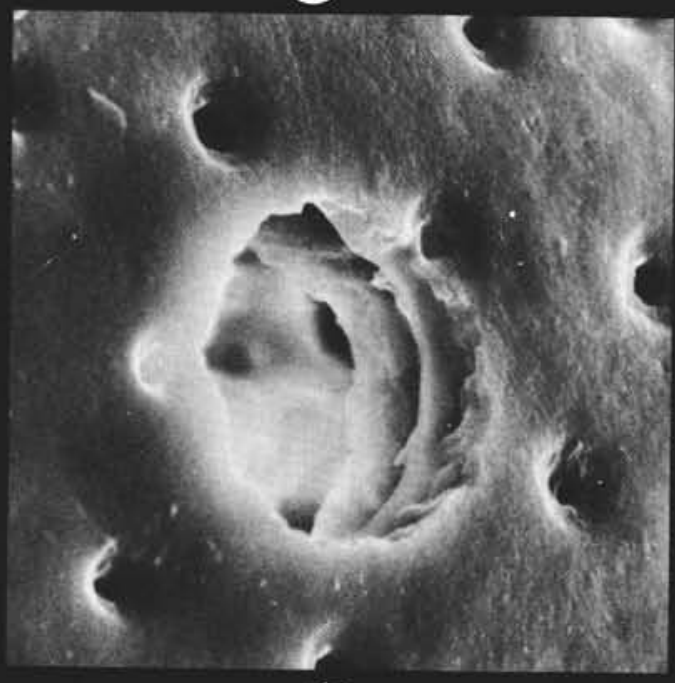

(5)

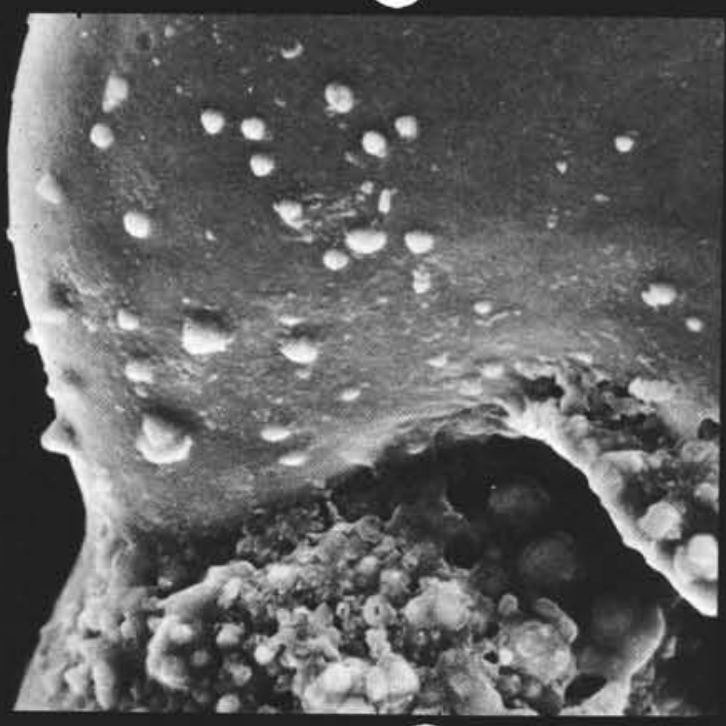

(4)

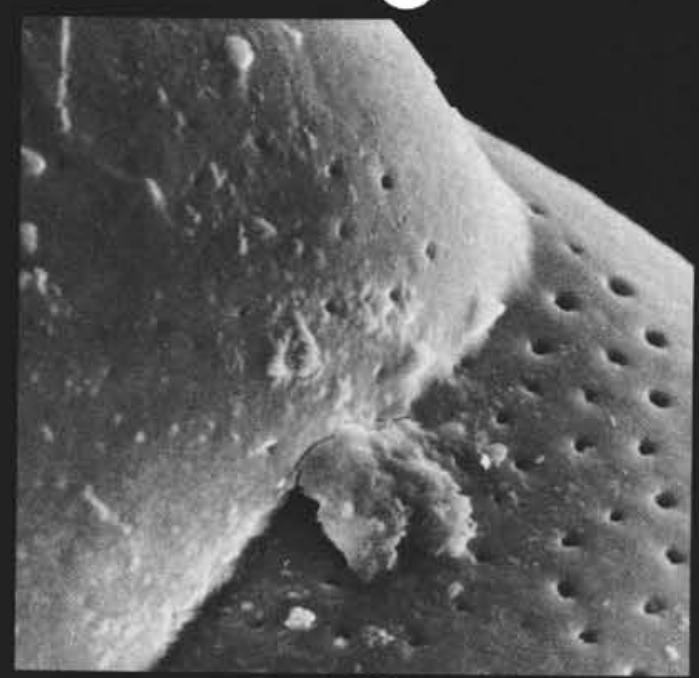

(6) 
M. B. CITA, M. A. CHIERICI, G. CIAMPO, M. MONCHAR MONT ZEI,

S. d'ONOFRIO, W. B. F. RYAN, R. SCORZIELLO

PLATE 15

Figure $1 \quad$ Globorotalia scitula (Brady) var. Spiral view; $\mathrm{X} 155$. Sample DSDP 132-6-3, 124-126 cm. Quaternary of Tyrrhenian basin.

Figure 2 Detail of Figure 1, showing the different structure between the early and the last formed chambers; $\times 360$.

Figure 3 Detail of Figure 1, showing the alveolar reticulation of early whorls; $\times 355$.

Figure 4 Detail of Figure 3, highly magnificated; $\times 770$.

Figure 5 Detail of Figure 4, showing same large pores of first whorl; $\times 3550$. 


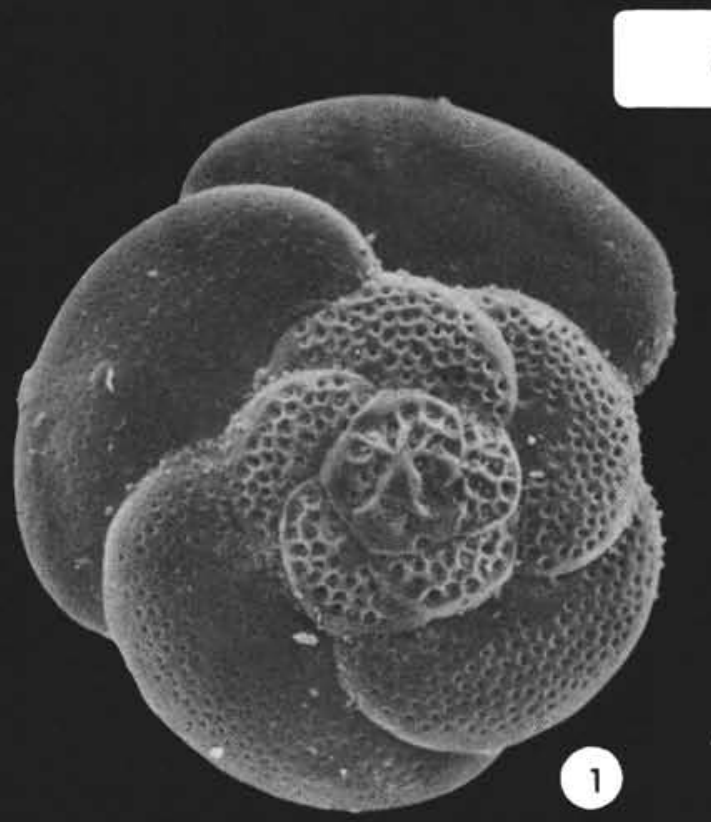

\section{PLATE 15}

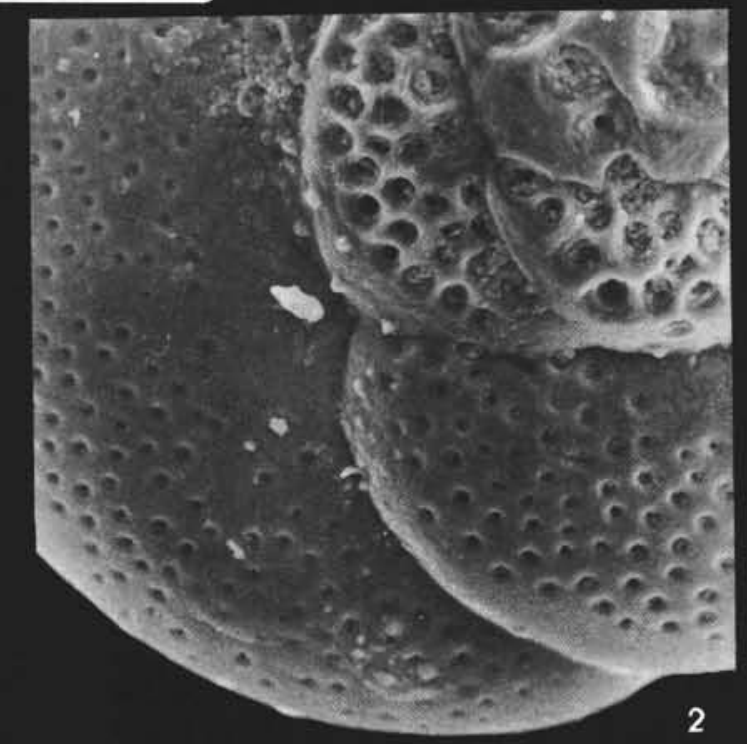

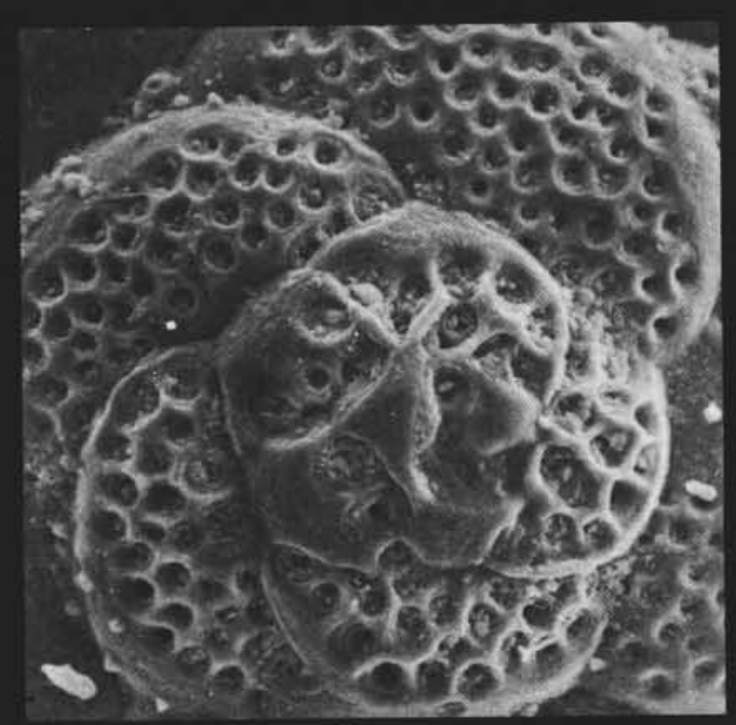

3

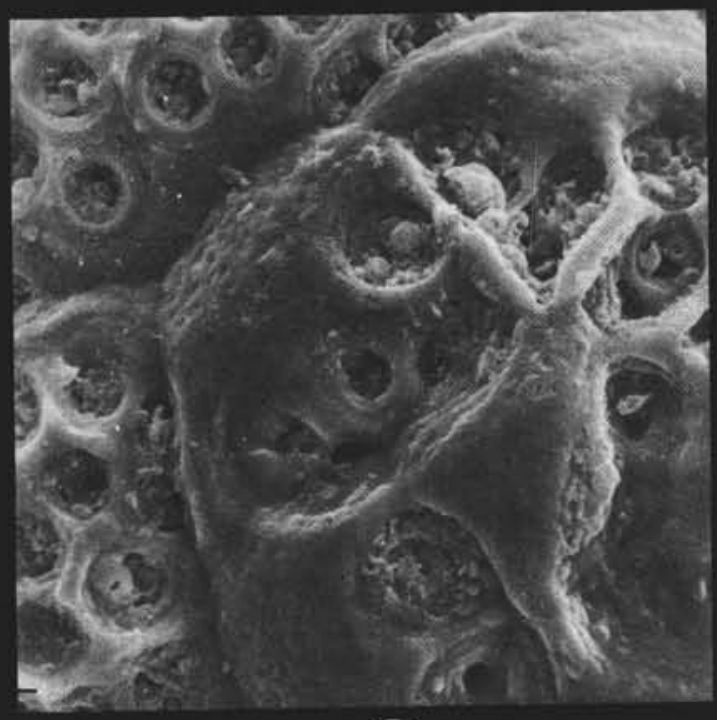

(4)

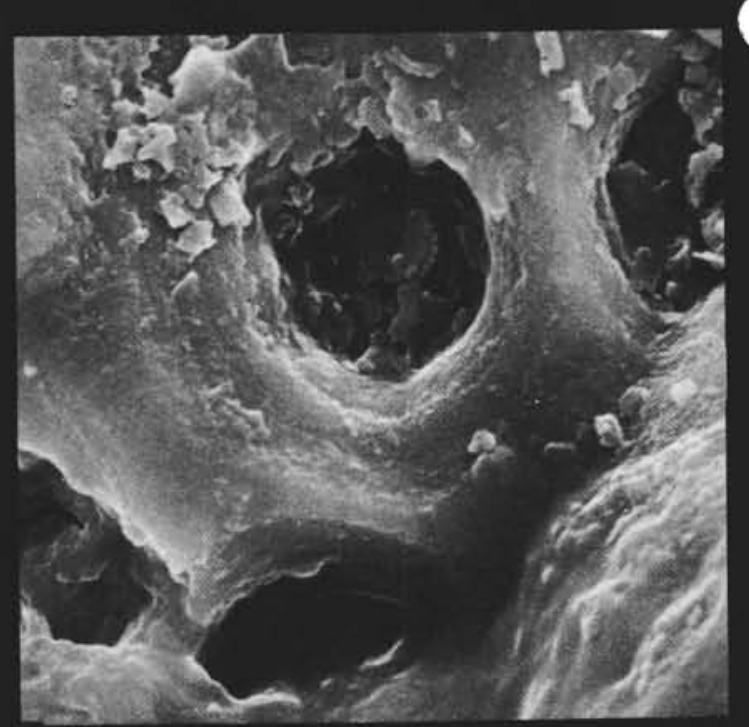

(5) 
PLATE 16

Figure $1 \quad$ Globorotalia truncatulinoides (d'Orbigny). Spiral view; $\times 120$. Sample DSDP 132-3-4, 71-73 cm. Pleistocene of the Tyrrhenian Basin.

Figure 2 As above, lateral view; $\times 130$.

Figure 3 Detail of Figure 1, showing the peripheral part of the last-formed chamber, with a series of knobs concentrated along the line separating the imperforate keel and the perforate chamber wall; $\times 800$.

Figure 4 Detail of Figure 1, showing the peripheral part of the penultimate chamber. Instead of the discrete knobs visible in Figure 3, we have here an irregularly ondulated and thickened margin of the peripheral keel. Many pores are partially filled with coccoliths (see arrows); $\times 800$.

Figure 5 Detail of Figure 1, showing the depressed intercameral suture which separates the last-formed and the penultimate chambers; $\times 800$.

Figure 6 Detail of Figure 2, showing the wide, umbilicalextraumbilical aperture. Subconical spines are developed all around the aperture; $\times 335$. 
PLATE 16
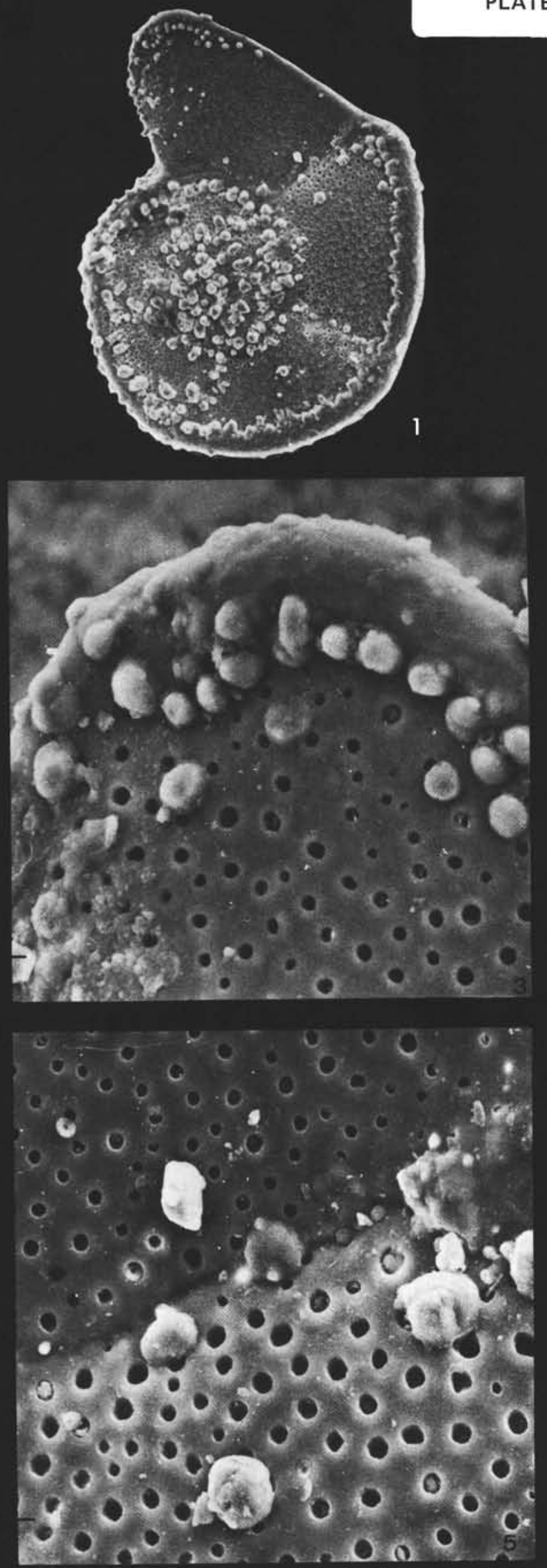

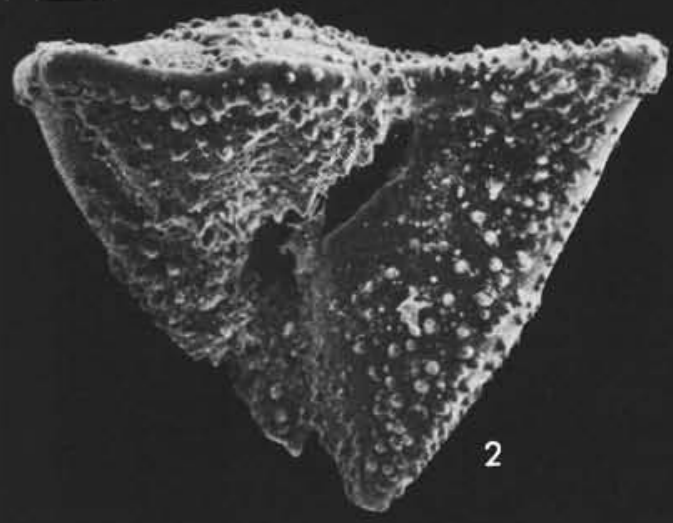

$\begin{array}{lllllllllllllll}0 & 0 & 0 & 0 & 0 \\ 0 & 0 & 0 & 0 & 0 & 0 & 0\end{array}$ - o o ol - $0.00^{0} 0^{0}$ $\left\{\begin{array}{llllll}0 & 0 & 0 & 0 & 0 & 0 \\ 0 & 0 & 0 & 0 & 0 & 0\end{array}\right]$

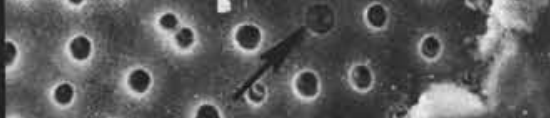
$\left.0.0 \begin{array}{lllll}0 & 0 & 0 & 0 & 0 \\ 0 & 0 & 0 & 0 & 0\end{array}\right]$ 0.0 .0 0000.00. $10000^{\circ} \mathrm{N}$
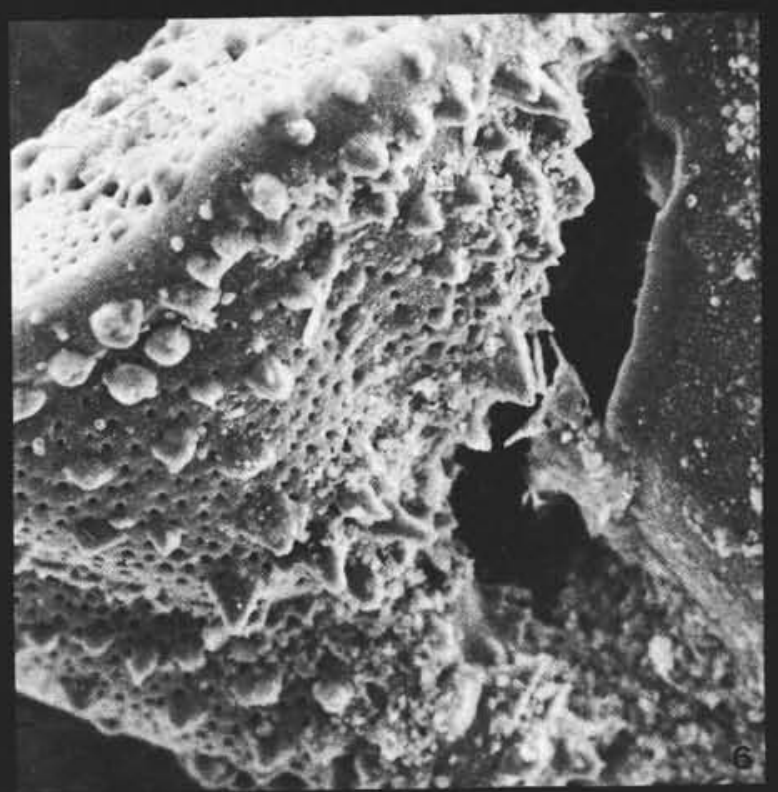


\section{PLATE 17}

Figure 1 Globorotalia tosaensis Takayanagi \& Saito. Umbilical view; X175. Sample DSDP 132-4-5, $20 \mathrm{~cm}$. Quaternary of the Tyrrhenian Basin.

Figure 2 Globorotalia truncatulinoides pachyteca Blow. Umbilical view of a left-coiling specimen; $\times 125$. Sample DSDP 132-3-4, 71-73 cm. Pleistocene of the Tyrrhenian Basin.

Figure 3 Globorotalia tosaensis Takayanagi \& Saito. Spiral view; X200. Sample DSDP 132-6-3, 86-88 cm. Lower Pleistocene of the Tyrrhenian Basin.

Figure 4 Detail of Figure 3, showing the highly calcified wall, the butresses covering the last-formed chamber (above) and the lack of a distinct imperforate keel; $\times 610$.

Figure $5 \quad$ Globorotalia truncatulinoides pachyteca Blow. Spiral view of a left-coiling specimen; $\times 135$. Sample DSDP $132-3-4,61-63 \mathrm{~cm}$. Pleistocene of the Tyrrhenian Basin.

Figure 6 Detail of Figure 5, showing the heavily calcified test, small pores and sparse buttressess. The thickening of the wall in $G$. truncatulinoides pachyteca is considered as an adaptative response to a deeper habitat with respect to $G$. truncatulinoides (compare wall structure in Plate 16); X435. 


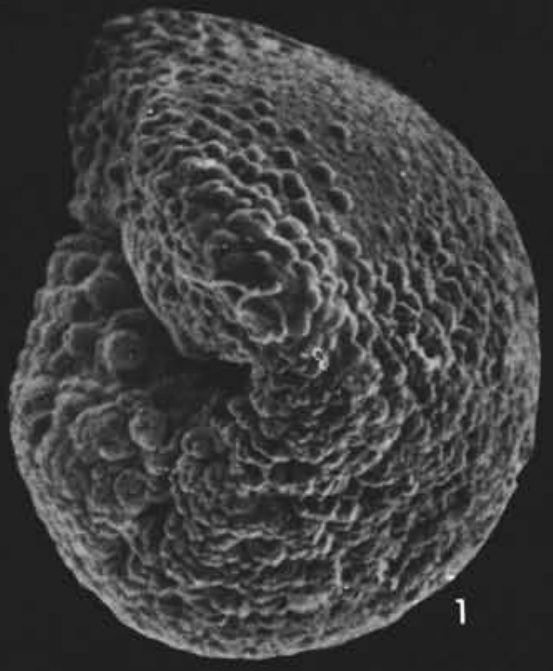

\section{PLATE 17}
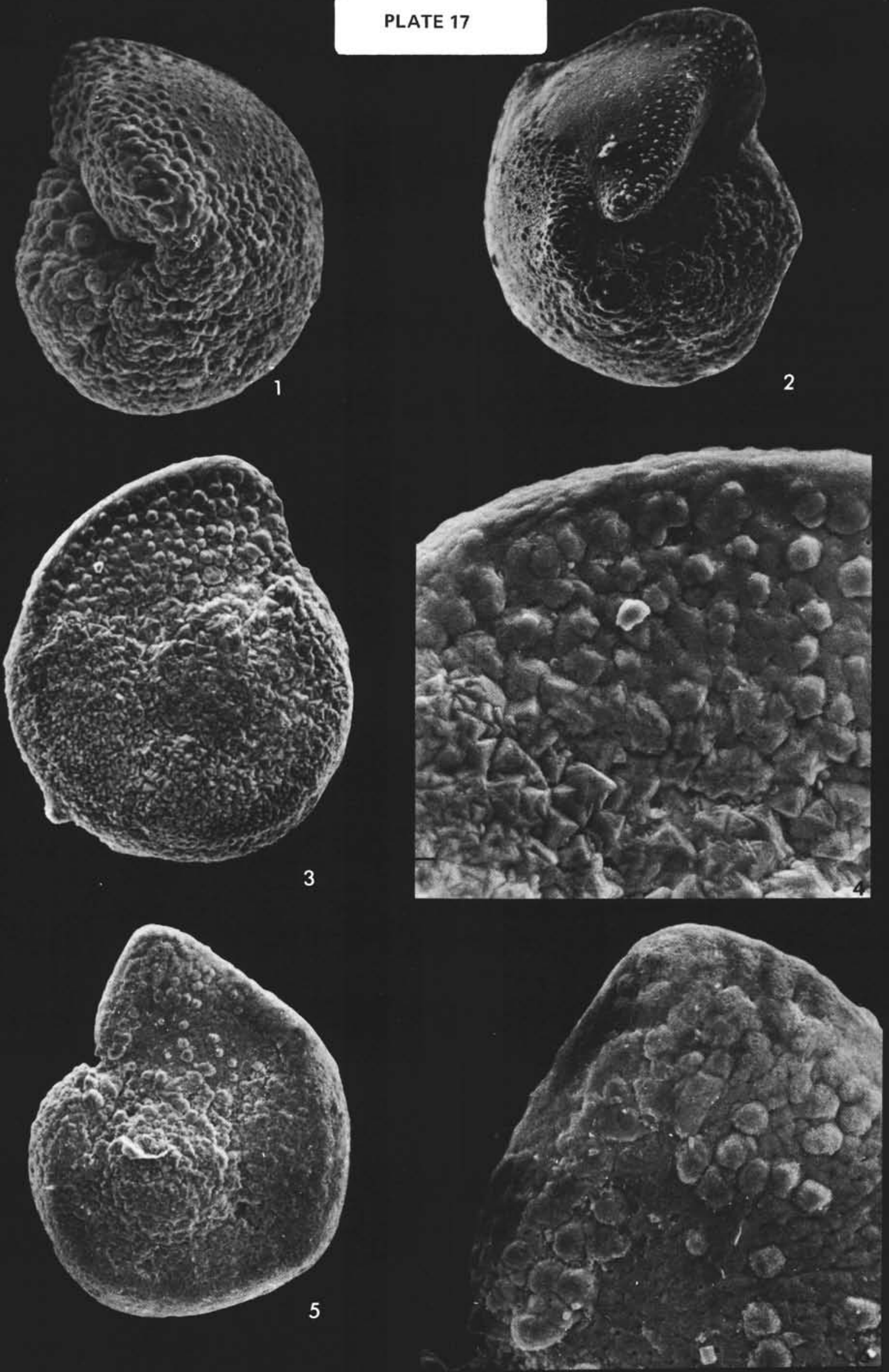
PLATE 18

Figure $1 \quad$ Globigerinita glutinata (Egger). Spiral view; $\times 150$. Sample DSDP $132-2-3,80-82 \mathrm{~cm}$. Quaternary of the Tyrrhenian Basin.

Figure 2 Detail of Figure 1 showing the depressed intercameral suture and finely pitted surface; $\times 460$.

Figure $3 \quad$ Globigerinita glutinata (Egger). Umbilical view; $\times 135$. Sample DSDP 132-2-3, 80-82 cm. Quaternary of the Tyrrhenian Basin.

Figure 4 Detail of Figure 3 (last-formed chamber) showing the extremely small pores, ranging in diameter from $1 / 2$ to $1 / 4$ micron.

Figure 5 Detail of Figure 3 (umbilical bulla) showing the extremely small, superficial pores and the pits, much smaller and spaced than on the chamber walls (see Figure 4), $\times 6720$. 


\section{PLATE 18}
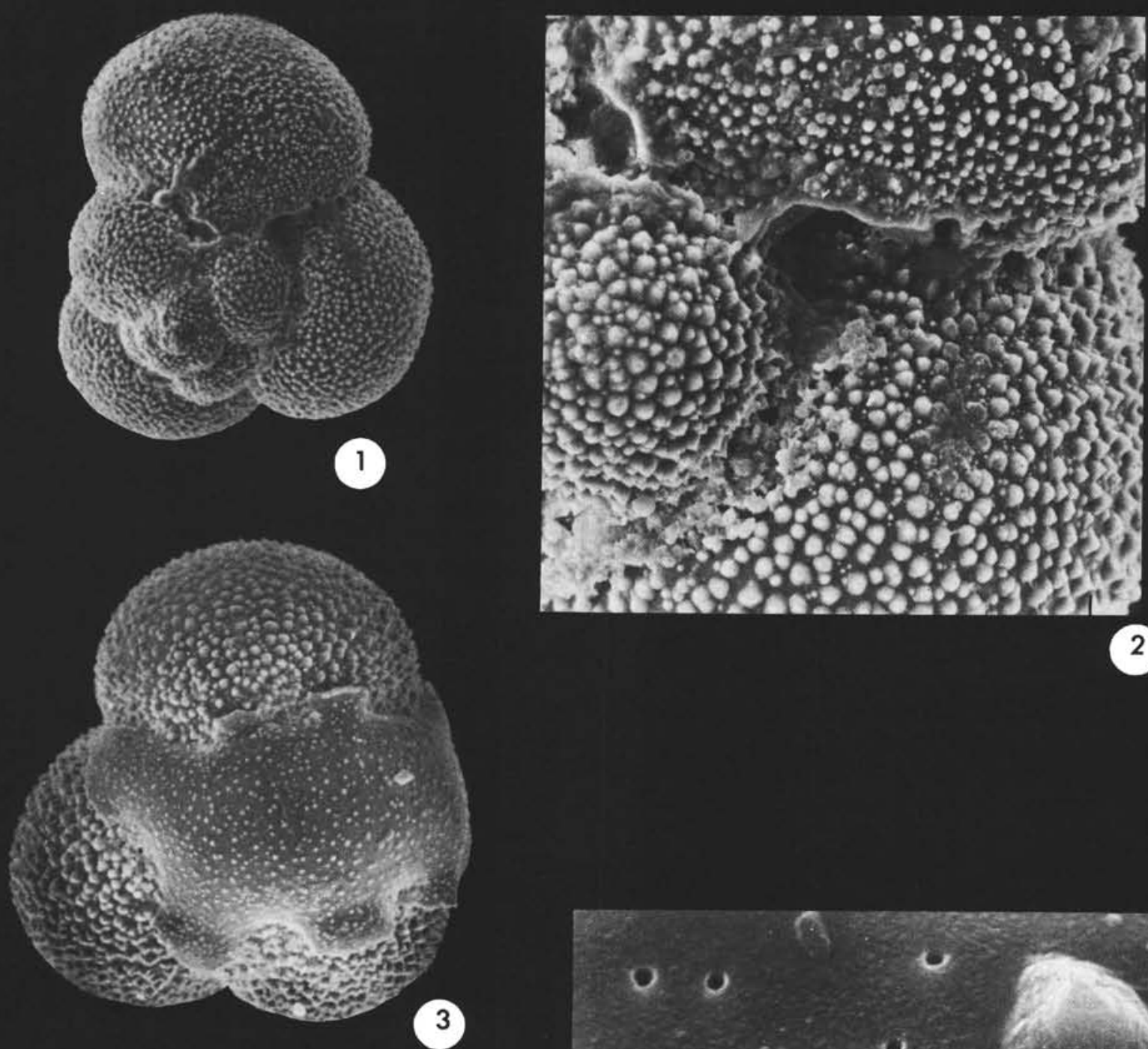
Figure 1

Figure 2

Figure 3

Figure 4

Figure 5

Figure 6

Figure 7
Hastigerina pelagica (d'Orbigny). Side view; $\times 115$. Sample DSDP 132-1-2, 75-77 cm. Quaternary of Tyrrhenian Basin.

Hastigerina pelagica (d'Orbigny). Apertural view; $\times 105$. Sample DSDP 132-1-4, 143-145 cm. Quaternary of the Tyrrhenian Basin.

Detail of Figure 2, showing the large aperture and the apertural lip; $\times 225$.

Detail of the wall of Hastigerina pelagica (d'Orbigny), showing the pores and the juncture of same spines; $\times 750$.

Detail of Figure 2, showing the particular structure of the spines; $\times 750$.

Detail of the spine a of Figure 5; $\times 2250$.

Detail of the spine $b$ of Figure $5 ; \times 2250$. 

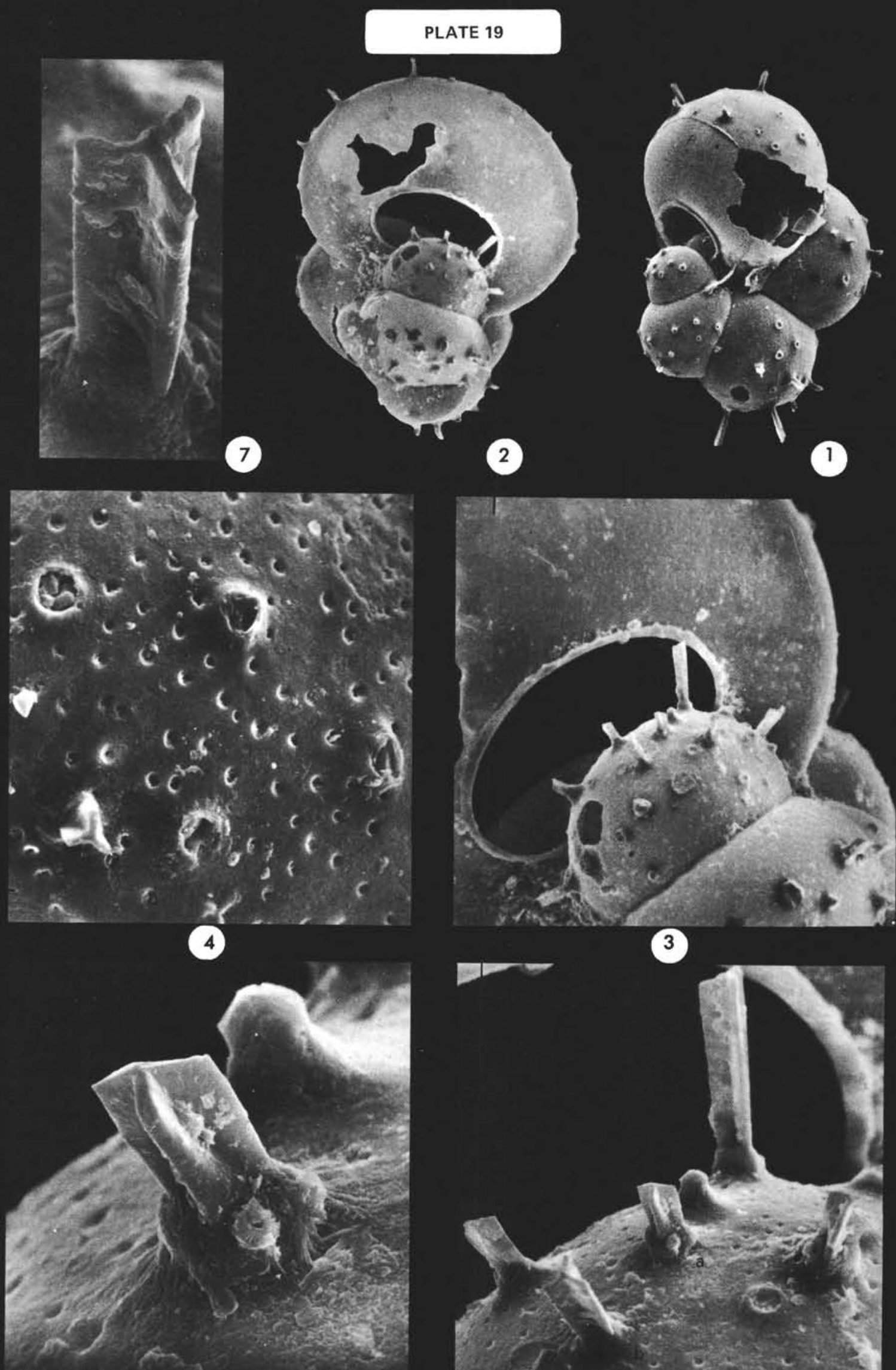

(6)

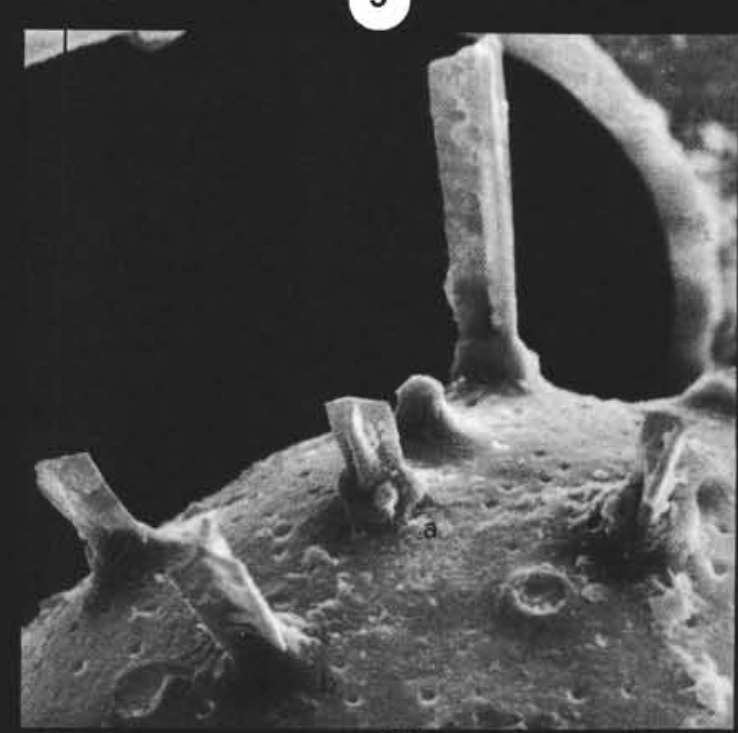

(5) 
PLATE 20

Figure 1 Hastigerina siphonifera (d'Orbigny). Spiral view; $\times 115$. Sample DSDP 132-6-1, 60-62 cm. Lower Pleistocene of the Tyrrhenian Basin.

Figure 2 Hastigerina siphonifera (d'Orbigny). Umbilical view; $\times 125$. Sample DSDP $132-6-1,60-62 \mathrm{~cm}$. Lower Pleistocene of the Tyrrhenian Basin.

Figure 3 Orbulina universa d'Orbigny, X160. Sample DSDP $132-6-3,86-88 \mathrm{~cm}$. Lower Pleistocene of the Tyrrhenian Basin.

Figure 4 Detail of Figure 2, showing the highly perforate and spinose chamber wall. Also visible are the apertures of the last three chambers; $\times 265$.

Figure 5 Detail of Figure 2 showing the difference between the normal pores of the wall and the large, funnel-like pores which fulfill the function of apertures in Orbulina; $\times 1400$. 


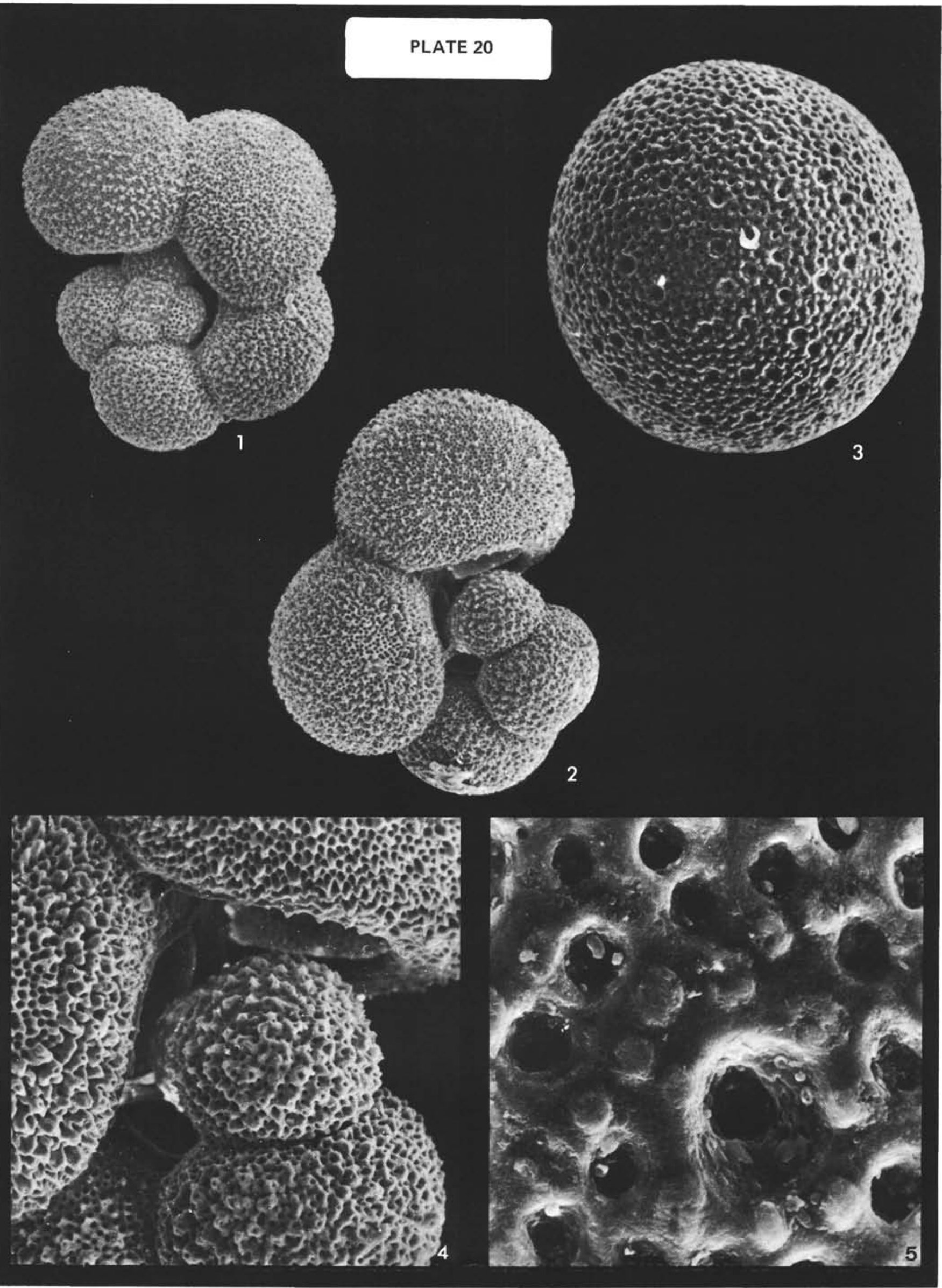

